UTILITY SCALE SOLAR PROJECTS IN CALIFORNIA:

AN INITIAL SURVEY

\author{
A Thesis \\ presented to \\ the Faculty of California Polytechnic State University, \\ San Luis Obispo
}

\author{
In Partial Fulfillment \\ of the Requirements for the Degree \\ Master of City and Regional Planning
}

By

Meaghan Mroz-Barrett

June 2015 
(c) 2015

\section{Meaghan Mroz-Barrett}

ALL RIGHTS RESERVED 


\section{COMMITTEE MEMBERSHIP}

TITLE:

Utility Scale Solar Projects in California: An Initial Survey

AUTHOR:

Meaghan Mroz-Barrett

DATE SUBMITTED: June 2015

COMMITTEE CHAIR: $\quad$ Adrienne Greve, Ph.D.

Associate Professor of City and Regional Planning

COMMITTEE MEMBER: Michael Boswell, Ph.D.

Professor of City and Regional Planning

COMMITTEE MEMBER: Chris Clark, J.D.

Lecturer of City and Regional Planning 


\author{
ABSTRACT \\ Utility Scale Solar Projects in California: An Initial Survey \\ Meaghan Mroz-Barrett
}

The lack of a comprehensive database for both concentrating and photovoltaic utility-scale solar power projects, those with a generation capacity of greater than $50 \mathrm{MW}$, hinders the ability of researchers and policy makers to examine the state of solar development in the state of California. This research project seeks to fill this gap in understanding by creating a database of proposed and developed projects in order to examine trends in proposals, process time, approvals, and construction starts. Existing literature was evaluated to determine potential factors for project success in approval and construction. Upon determination of these factors, the project database was developed through use of publicly available data and extensive Internet searches of planning documents, industry releases, and articles on existing and proposed projects. The completed database, containing eighty projects, was analyzed to provide an initial look at the overall state of solar project development in California. This report details these early findings as well as areas for further research. The analysis indicates that, while California has a high amount of proposed projects and generation capacity, many projects do not reach the end of the public approval process and fewer still enter construction and operation. 


\section{TABLE OF CONTENTS}

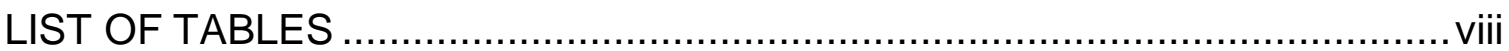

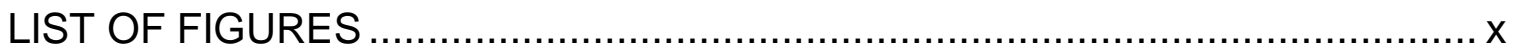

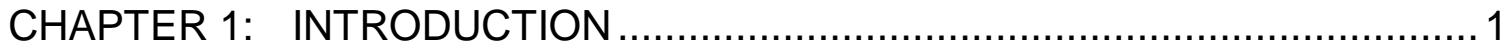

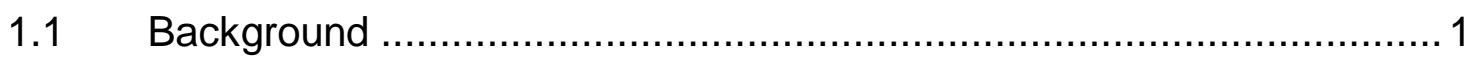

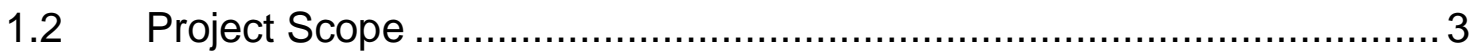

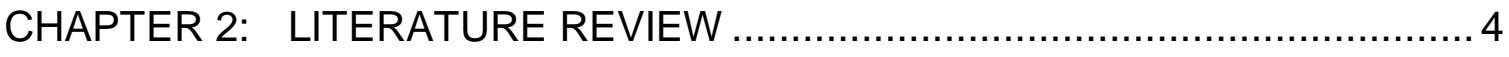

2.1 Status of Renewable Energy Development .............................. 4

Current State of Renewable Energy Development .......................... 4

Potential for Renewable Energy Growth ................................6 6

2.2 Status of Renewable Energy in California ................................... 8

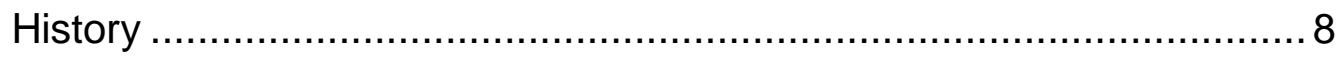

Potential for Renewable Energy Development in the State ................. 10

Trends in Solar Development in the State............................... 10

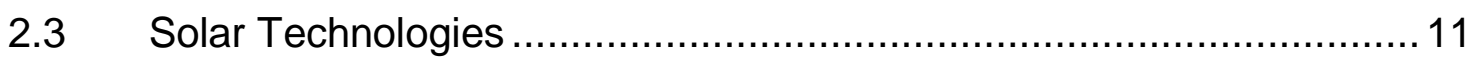

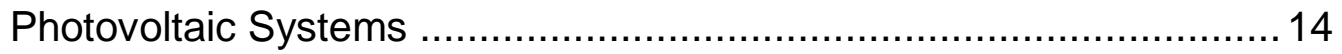

Concentrating Solar Power ................................................ 15

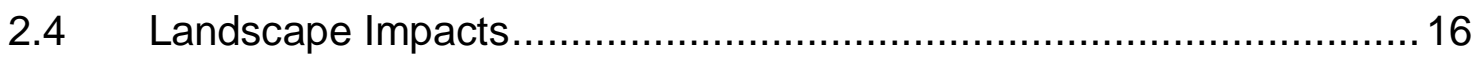

2.5 Public Acceptance of Utility Scale Solar Energy ........................ 17

2.6 Factors for Successful Development.................................. 19

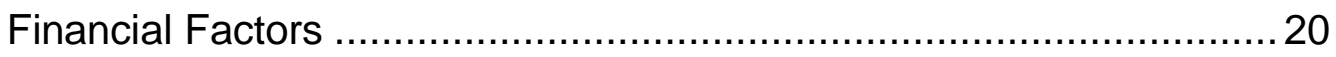

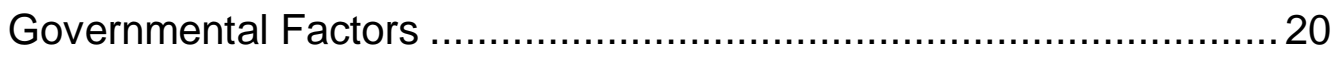




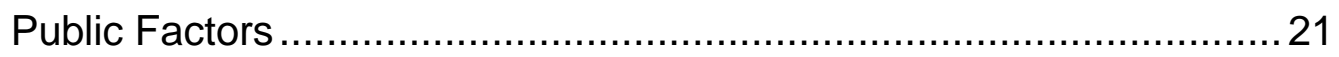

2.7 Solar Power Plant Public Planning Approval Process .......................21

California Energy Commission Process ............................................ 22

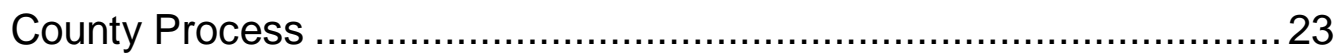

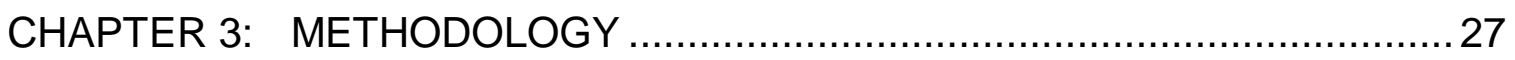

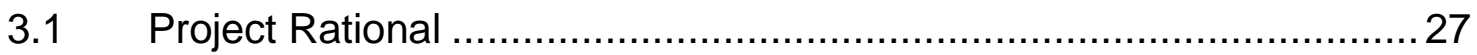

3.2 Complications to Creating Database ...............................................29

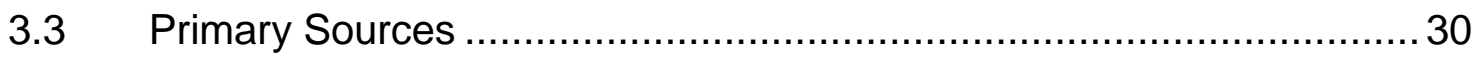

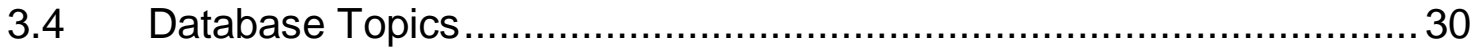

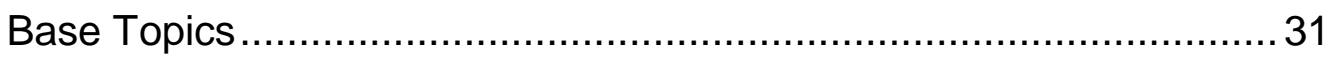

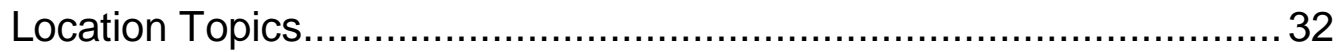

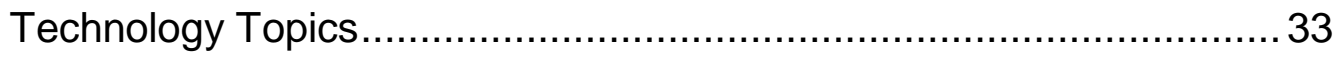

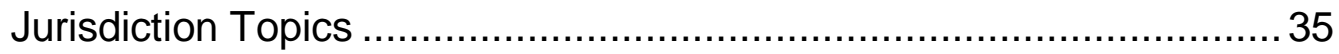

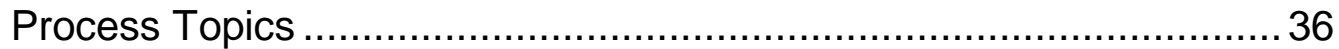

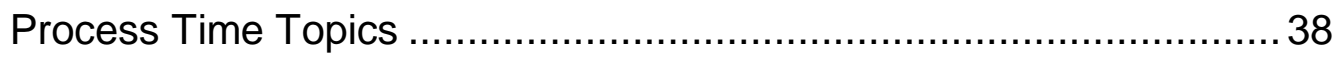

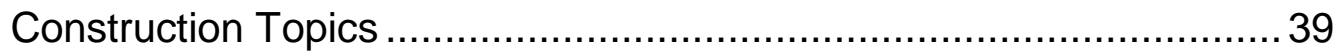

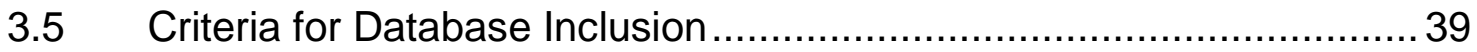

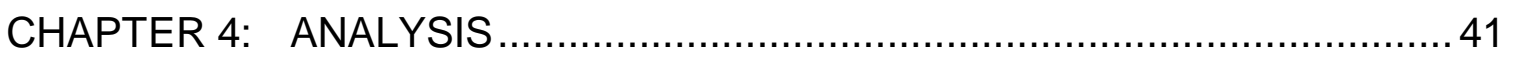

4.1 Basic Project Numbers …........................................................... 41

4.2 California Energy Commission Jurisdiction ...................................50

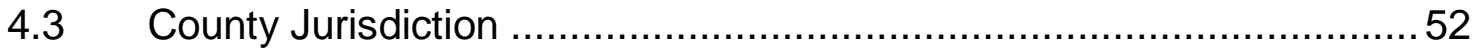

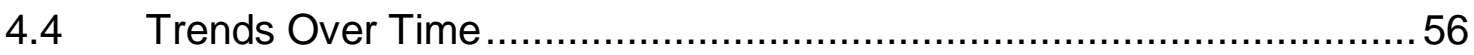


CHAPTER 5: CONCLUSIONS

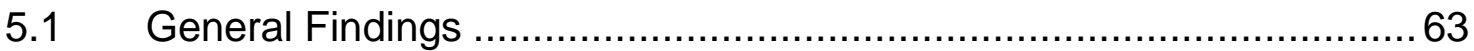

5.2 Comparing the California Energy Commission and County

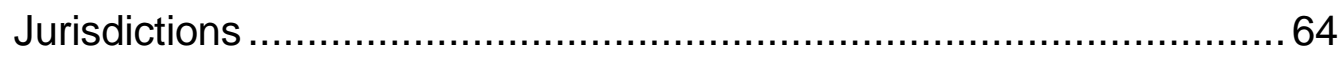

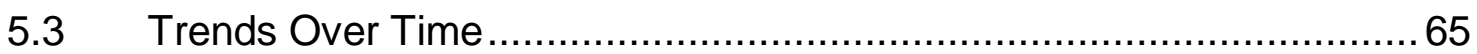

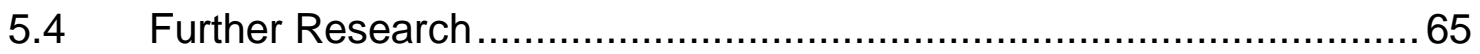

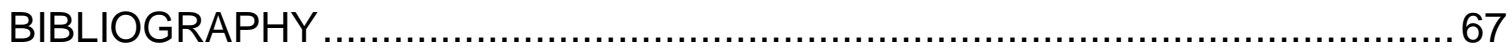
APPENDICES

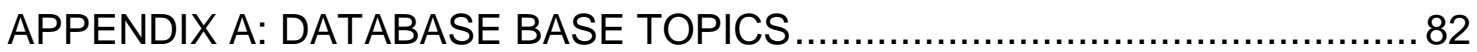

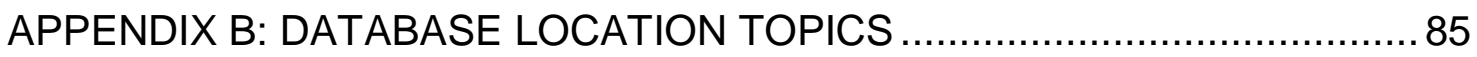

APPENDIX C: DATABASE TECHNOLOGY TOPICS …............................. 88

APPENDIX D: DATABASE LAND USE TOPICS …….............................. 92

APPENDIX E: DATABASE JURISDICTION AND PROCESS TOPICS ............96

APPENDIX F: DATABASE PROCESS TIME TOPICS ............................. 100

APPENDIX G: DATABASE CONSTRUCTION TOPICS ............................ 104 


\section{LIST OF TABLES}

Table 2.1 California's Renewable Energy Potential (CEC, 2011c) ...................11

Table 3.1 Rational for Base Topics ........................................................... 31

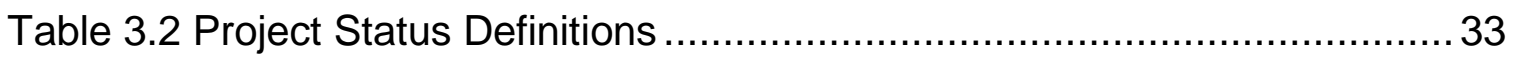

Table 3.3 Rational for Location Topics......................................................... 33

Table 3.4 Rational for Technology Database Topics...................................... 34

Table 3.5 Rational for Land Use Topics ...................................................... 35

Table 3.6 Rational for Jurisdiction Topics ................................................. 36

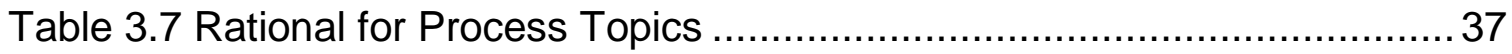

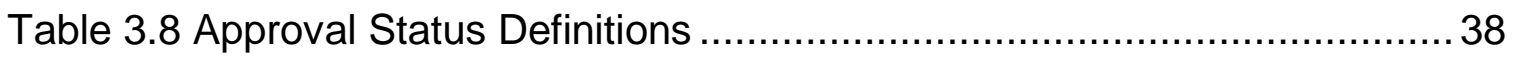

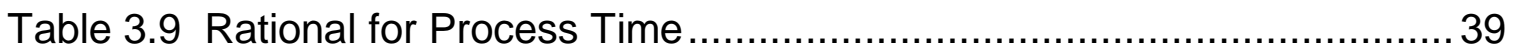

Table 3.10 Rational for Construction Topics .............................................. 40

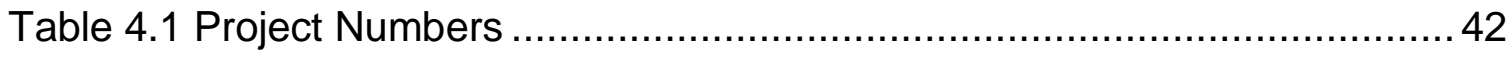

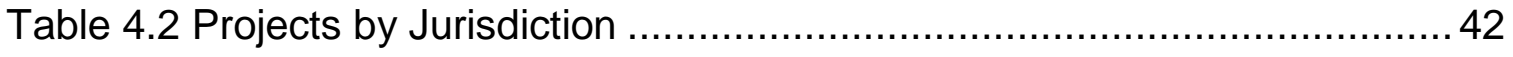

Table 4.3 Projects by Project Status .......................................................... 43

Table 4.4 Projects by Operational Status................................................. 44

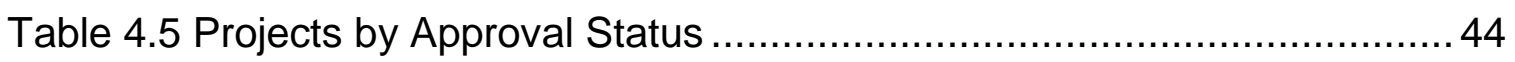

Table 4.6 Projects by Power Purchaser ...................................................... 45

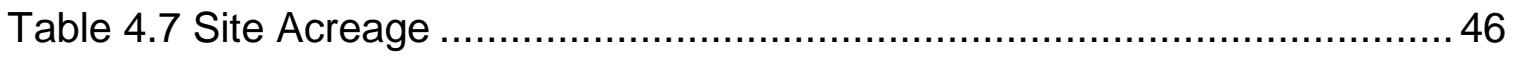

Table 4.8 Total Site Acreage by Original Land Use ..................................... 47

Table 4.9 Proposed Generation Capacity (MW) .......................................... 48

Table 4.10 Average Public Process Time by Technology ................................ 49

Table 4.11 Average Public Process Time by Jurisdiction ................................5 50 
Table 4.12 California Energy Commission Jurisdiction: Number of Projects, Approvals, and Construction Starts ................................................ 51

Table 4.13 California Energy Commission Jurisdiction: Site Area .................... 52

Table 4.14 California Energy Commission Jurisdiction: Average Public

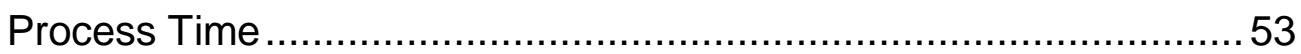

Table 4.15 County Jurisdiction: Total Number of Projects, Approved Projects, Mitigated Negative Declarations, and Construction Starts.......................54

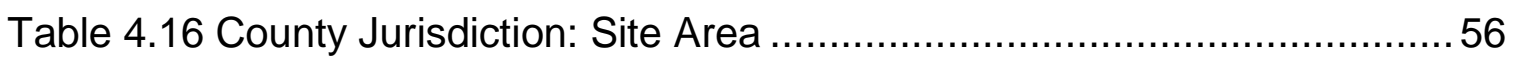

Table 4.17 County Jurisdiction: Average Total Process Time (Days) ................57

Table 4.18 Proposed Projects by Process Start Year ..................................... 59

Table 4.19 Average Proposed Generation Capacity by Process Start Year .......60

Table 4.20 Average Proposed Total Site Acreage by Process Start Year ......... 61

Table 4.21 Total Approved Projects by Process End Year............................... 62

Table 5.1 Percent Projects by Initial Technology .......................................... 63

Table 5.2 Comparison of Percent Projects Approved and Constructed by

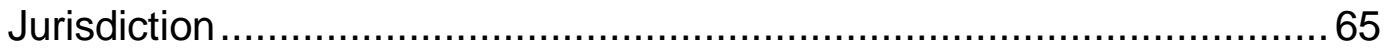




\section{LIST OF FIGURES}

Figure 2.1 World Electricity Production from All Energy Sources in 2012 (TWH) ("World Electricity Production from All Energy Sources in 2012 (TWh), " 2012) ............................................................... 5

Figure 2.2 United States Energy Production by Source in 2014 (EIA, 2014) ....... 6

Figure 2.3 Concentrating Solar Resource of the United States (NREL, 2010a) . 12

Figure 2.4 Photovoltaic Solar Resource of the United States (NREL, 2010b) .... 12

Figure 2.5 Existing Renewable Facilities in California (CEC, 2011c, p. 40) ....... 13

Figure 2.6 Example of a photovoltaic development (SOLAREIS, 2015) ............ 14

Figure 2.7 Example of a CSP development (Mingasson, 2015) ....................... 15

Figure 2.8 California Energy Commission Small Power Plant Exemption

Process (CEC, 2006, p. 17) …................................................ 23

Figure 2.9 Sample County Planning Process Adapted from Riverside County Development Process (Riverside County Planning Department, 2015) ... 25

Figure 2.10 Sample EIR Process Adapted from San Diego County EIR

Flowchart (County of San Diego Department of Planning and Land Use Regulatory Planning Division, 2003) ............................26

Figure 4.1 Total Projects by Count............................................................ 42

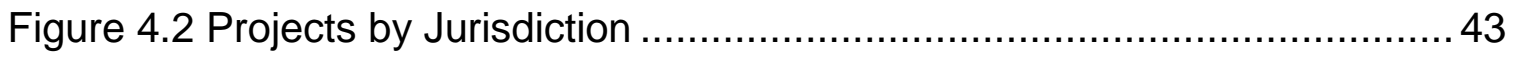

Figure 4.3 Average and Median Proposed Total and Developed Site Acreage .. 46

Figure 4.4 All Projects: Total Proposed Site Acreage by Land Use ................... 47

Figure 4.5 Average Public Process Time (Days) by Technology ....................... 49 
Figure 4.6 California Energy Commission Jurisdiction: Number of Projects, Approvals, and Construction Starts.....

Figure 4.7 California Energy Commission Jurisdiction: Average Process

Time Compared to Number of Projects and Approvals by County.....53

Figure 4.8 County Jurisdiction: Projects, Approvals, Mitigated Negative

Declarations, and Construction 55

Figure 4.9 County Jurisdiction: Average Process Time Compared to Number of Projects and Approvals

Figure 4.10 Proposed Projects by Process Start Year

Figure 4.11 Average Proposed Generation Capacity (MW) by Process Start

Year. 60

Figure 4.12 Average Proposed Total Site Acreage by Process Start Year........ 61

Figure 4.13 Approved Projects by Process End Year 62 


\section{CHAPTER 1: INTRODUCTION}

\subsection{BACKGROUND}

The siting of large energy production facilities is not a new issue in the state of California, literature as far back as the 1970s examines the planning and effect of these projects (Ball et al., 1972; Papetti, Dole, \& Hammer, 1973). The planning and development of these facilities is a complex issue that requires balancing the public need for increased energy production with the potential adverse health and quality of life effects on the local population. California's planning policies, including the California Environmental Quality Act (CEQA), require substantial public involvement in the review process as a way of ensuring the local communities have a voice in the process.

Renewable energy $(\mathrm{RE})$ facilities are no exception to the consideration of the greater public good versus adverse local effects. The state has a vested interest in encouraging increased production of energy from RE sources in order to reduce green house gas (GHG) emissions and mitigate climate change. Energy production contributes a substantial proportion of the GHG emissions in the United States and, in order for California to meet its emission reduction goals, RE must play a role. California has enacted numerous policies, including the Renewable Portfolio Standard (RPS), aimed at increasing the proportion of energy obtained through RE sources.

The ambitious California RPS, created by Senate Bill 1078 in 2002, sets some of the highest renewable energy (RE) targets for power companies in the nation (CEC, 2010)). The original RPS mandated that RE comprise $33 \%$ of the energy produced in the state and was designed to reduce the state's dependence on natural gas (California Public Utilities Commission, 2009). The initial standard was successful in encouraging a range of RE development in the state including wind and solar energy (California Public Utilities Commission, 2009). Additional legislation, such as Assembly Bill 32 which mandated California reduce carbon emissions to 1990 levels by 2020, supported this trend. Due to this success, Governor Jerry Brown further 
challenged utility companies by raising the RPS standard to $50 \%$ renewable energy by 2030 . Assembly Bill 197, introduced in January of 2015, formalizes this increase.

While a range of RE sources are being developed in the state, solar energy has the largest potential for growth (Stillwell, 2011). According to the California Energy Commission (CEC), $99 \%$ of the technical growth potential for RE in the state is solar energy, with photovoltaic energy representing the majority of that potential (CEC, 2011b). Large-scale solar developments are not new to California. The first large-scale solar concentrating solar projects were built in the state in the 1980s. Despite the early beginning, the state did not see many new developments in projects of this scale until the passage of RPS.

Despite the increased $R E$ requirements, the positives of any specific development must be weighed against the substantial impacts these large-scale facilities have on the landscape and lives of those who live near them. RE facilities face unique issues during their siting and development that differ from those faced by traditional power plants (Carlisle, Kane, Solan, Bowman, \& Joe, 2015; Heras-Saizarbitoria, Cilleruelo, \& Zamanillo, 2011). While RE energy has generally wide-spread public acceptance, there is often significant opposition to specific projects at the local level and considerable research has been conducted on bridging this gap (Bell, Gray, \& Haggett, 2005).

Solar power is not immune from this effect. Solar facilities differ from traditional power generation facilities in terms of the amount required land, location specificity, and the types of impacts on the site (Chiabrando, Fabrizio, \& Garnero, 2009; Pasqualetti, 2011). Project sites often require hundreds of acres of land in often rural or under developed areas, and the projects are large new industrial construction with the potential for high visual impact. As a result, new solar facilities have faced strong challenges to their location on private, state, or federal lands from local residents, activists, and environmental organizations (Groom \& Chan, 2011; Peter Maloney, 2008; Sahagun, 2014; Woody, 2011).

With the substantial state interest in expanding RE development, the state and local agencies have sought to minimize challenges to these projects by creating streamlined processes to move projects through the planning process quickly. Governor Jerry Brown signed into law 
legislation that acts to limit CEQA legal challenges to $R E$ projects as well as exempting projects from certain types of environmental assessments (Grueneich, Gold, Imwalle, \& Esformes, 2011). The California Energy Commission (CEC), which over sees the development of concentrating solar projects (CSPs) over $50 \mathrm{MW}$ in size, has a fast track approval process for these developments with the goal of 1 year from application to final hearing (CEC, 2007). While local county processes differ greatly across jurisdictions, several have attempted to shorten the process time for these projects either through zoning changes or through exempting projects from a full CEQA review through the use of a mitigated negative declaration.

Despite the significant push to develop RE projects and the measures enacted to ensure a speedy planning process, no research has been conducted to determine whether these measures have been effective in promoting project approval and construction. State documents focus primarily on the number of projects and generation capacity proposed, while academic research has focused on the public acceptance of projects (CEC, 2012a; Stillwell, 2011; Weil, 2009). This research project seeks to fill this gap in understanding by creating a database of proposed and developed projects in order to examine trends in proposals, process time, approvals, and construction starts.

\section{$1.2 \quad$ PROJECT SCOPE}

This project focuses on utility scale solar projects in the state of California. Utility scale is defined for the purpose of this research as those projects with a proposed generation capacity of $50 \mathrm{MW}$ or greater. This criterion reflects the standard that the California Energy Commission uses to determine its jurisdiction over large solar thermal projects (CEC, 2007). This research project sought to develop an exhaustive database of proposed and existing solar projects, both photovoltaic and concentrating solar, after research found that no comprehensive database was publicly available. Existing literature was reviewed to determine potential factors for project success in approval and construction. Upon determination of these factors, the project database was developed through use of publically available data and Internet searches of planning documents, industry releases, and articles on existing and proposed projects. 


\section{CHAPTER 2: LITERATURE REVIEW}

Because this project creates a database to serve as the basis for further research into State of California utility-scale solar development, it is necessary to place this research in the context of the factors influencing project development and approval. This section begins by examining the growth of renewable energy $(\mathrm{RE})$ globally and that is followed by a discussion of the role California policy has played in encouraging renewable expansion at the state level. The two main solar technologies used at the utility scale and their impact on their surrounding landscape and environment are then examined. Public acceptance of RE is analyzed and the current pubic planning processes for solar power plants within the state is examined. This chapter concludes with a look at what is currently known about the components of a successful RE project.

\subsection{STATUS OF RENEWABLE ENERGY DEVELOPMENT}

Worldwide demand for energy is projected to increase 60\% from 2002 to 2030 (Solangi, Islam, Saidur, Rahim, \& Fayaz, 2011). Within the United States demand is expected to rise $1.5 \%$ per year until 2030 while production per capita is expected to fall during the same period (Felder \& Haut, 2008). Policymakers have recognized the need for secure, dependable sources of energy that are sensitive to the environment to meet this demand (Sissine, 2007; Stillwell, 2011). $\mathrm{RE}$ sources represent a potential solution to meet the rising global and national energy needs (Gatrell \& Jensen, 2009; Sayigh, 2009).

\section{Current State of Renewable Energy Development}

Despite the wide range of RE sources, it is underutilized and accounts for only a fraction of worldwide and national energy production (Pimentel et al., 2002). Approximately 70 percent of the electricity in the United States is produced from coal, natural gas, or petroleum powered plants compared to four percent produced by non-hydroelectric renewable energy sources (Center for Climate and Energy Solutions, 2011). Globally, the numbers are similar: 68 percent of electricity is generated using coal/peat, oil, and natural gas sources, and approximately 3 percent 
comes from renewable, non-hydroelectric sources (Center for Climate and Energy Solutions, 2011). Hydroelectric power is often grouped separately from other RE due to its higher rate of development, as well as its unique environmental impacts.

In 2003, the countries with the highest proportion of RE generation were those in Latin America and Canada at $70.9 \%$ and $59.2 \%$, respectively, due to a focus on hydropower (Baratta, 2011). The United States (2.4\%) and Europe (3.6\%) lead global production for non-hydro RE and also are among the leaders in utility or grid connected solar (Baratta, 2011). Currently, the primarily RE resources used globally are biomass, hydropower, with geothermal a distant third place, and solar and wind lagging far behind (Resch et al., 2008). See Figure 2.1 for a breakdown of world energy production by source and Figure 2.2 for the United State's electricity production by energy source.

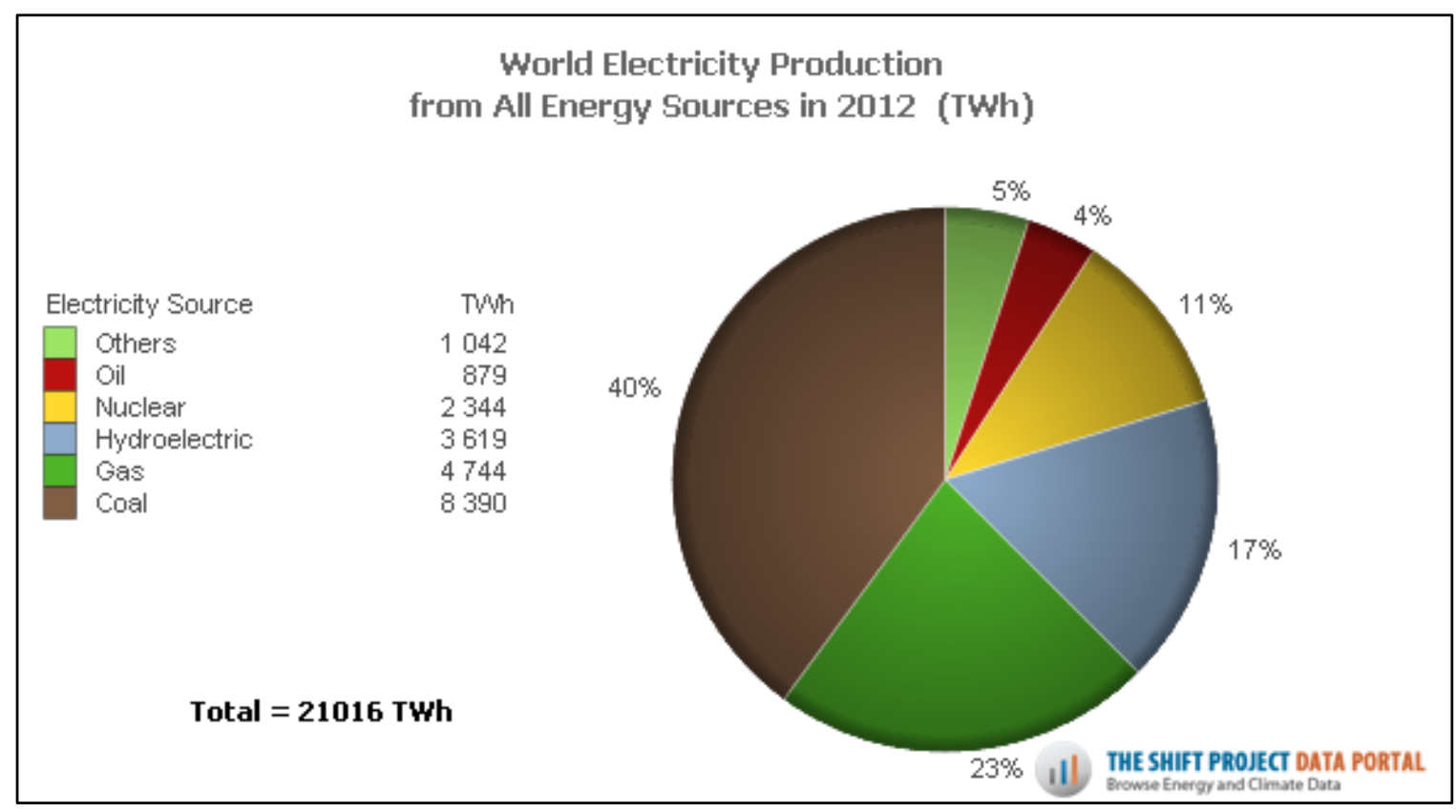

Figure 2.1 World Electricity Production from All Energy Sources in 2012 (TWH) ("World Electricity Production from All Energy Sources in 2012 (TWh)," 2012) 


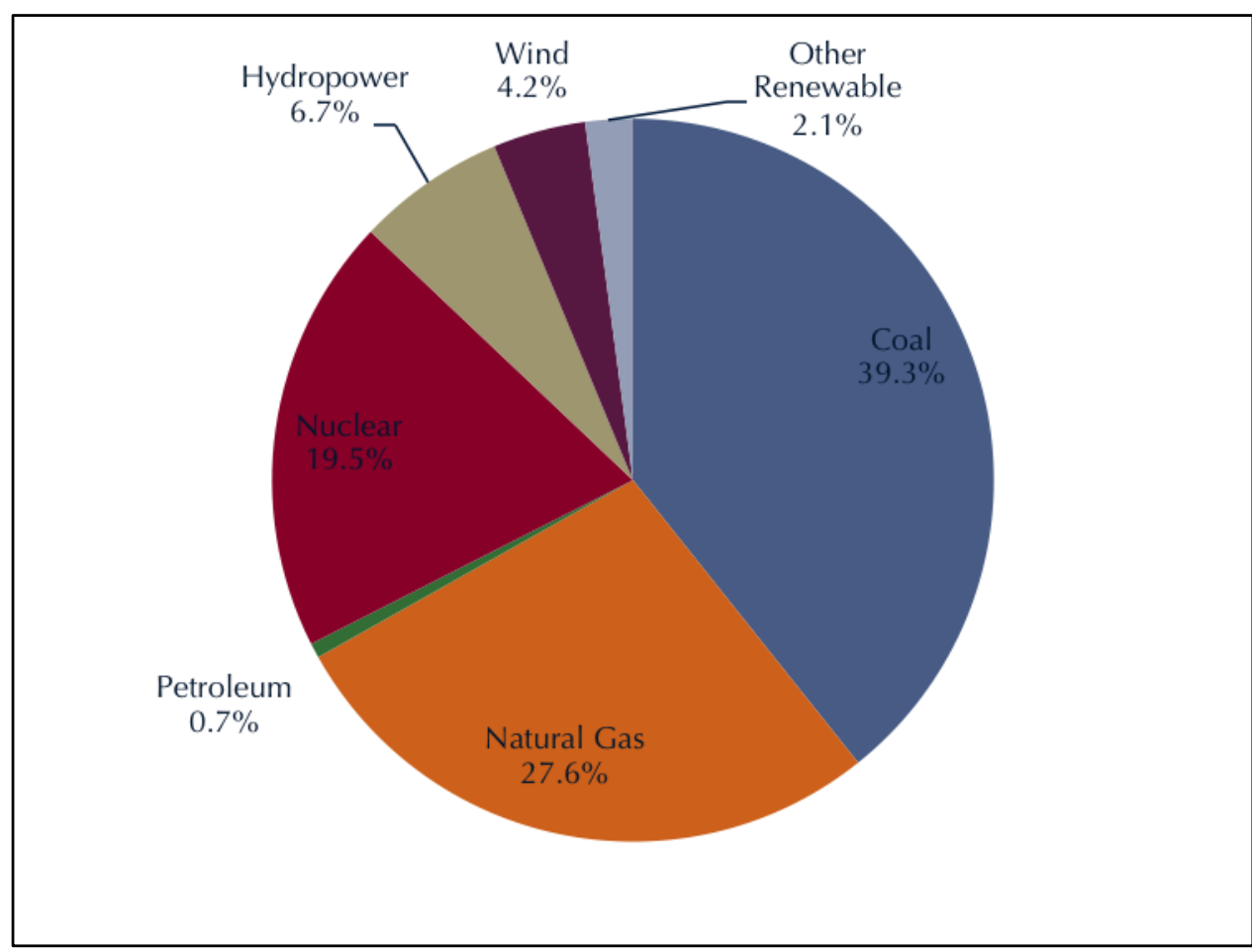

Figure 2.2 United States Energy Production by Source in 2014 (EIA, 2014)

One of the main factors responsible for keeping RE an underutilized resource is the cost of developing these facilities compared to traditional hydrocarbon based energy production. In recent years, prices for RE technologies have fallen, particularly for photovoltaic cells, and fossil fuel based energy costs have increased. However, RE has yet to become fully competitive with traditional modes of electricity generation, even when environmental effects are considered (Timilsina, Kurdgelashvili, \& Narbel, 2012). Other factors contributing to the low use of renewable energy include political, institutional, and acceptance barriers (Timilsina et al., 2012). RE, as with traditional energy resources, also has geographical limitations, with higher levels of suitability for different RE resource use in specific regions as well as variable regional costs for development (Baratta, 2011; Gatrell \& Jensen, 2009; Pimentel et al., 2002; Resch et al., 2008).

\section{Potential for Renewable Energy Growth}

While the current utilization of RE resources is low compared to more traditional energy sources, renewables remain a strong potential source for future energy needs (Baratta, 2011; 
Resch et al., 2008). There is a wide range of the estimated generation potential from RE up to 100 percent of global energy requirements if these resources were more developed (Baratta, 2011; Jacobson \& Delucchi, 2011; Resch et al., 2008). Other authorities suggest that renewable energy sources could potentially provide for current and future demand several times over (Resch et al., 2008). Policy makers are increasingly encouraging this growth due to concerns with climate change and energy security (Gatrell \& Jensen, 2009; Sayigh, 2009).

Because traditional fossil fuel is used for the largest proportion of energy generation, electricity production accounts for 33-percent of the total greenhouse gas emissions (GHG) in the United States, making the U.S. one of the largest global $\mathrm{CO}_{2}$ emitters (Center for Climate and Energy Solutions, 2011). Energy and climate policies have identified RE development as a viable strategy for reducing greenhouse gas emissions from electricity and energy generation (American Planning Association, 2011; Baratta, 2011; Carley, 2011; Sen, 2008). Within the US, researchers believe that it will be possible to meet the strictest GHG reduction goals through the replacement of fossil fuel energy sources with renewable sources, particularly solar (Fthenakis, Mason, \& Zweibel, 2009; Jacobson \& Delucchi, 2011).

In addition to concerns about GHG emissions, countries have been aware of the need to have secure and independent sources of energy (Gatrell \& Jensen, 2009; Sayigh, 2009). Countries have sought ways to reduce dependence on foreign energy imports since the oil embargos of the 1970s. These embargos caused an early shift towards coal and nuclear energy for electricity production (Hughes, 2009). The continuing instability in the Middle East makes this a continuing issue in energy policy. In the United States, this has translated into legislation with the Energy Independence and Security Act of 2007 (P.L. 110-140, H.R. 6). This bill specifically focuses on shifting energy development priorities to $R E$ as a way to reduce foreign oil dependence.

In response to rising demand, climate change and other motives, including energy independence, countries around the world are utilizing a variety of policies to encourage RE development. This includes feed-in-tariffs, tax policies, energy portfolio requirements, and cap and trade laws (Solangi et al., 2011). While the true effectiveness of these policies is unknown, it 
is likely they will encourage RE development. Local conditions including availability of resources, availability of financing, and public acceptance or opposition, will determine the form RE development will take.

\subsection{STATUS OF RENEWABLE ENERGY IN CALIFORNIA}

\section{History}

California has a long history of encouraging renewable energy development through policy decisions. As early as the 1970s, the California Energy Commission (CEC) was working to create opportunities for renewable energy (Weil, 2009). The CEC projected in a 1983 report that by year 200050 - to 60 -percent of the state's energy would come from renewable sources (CEC, 1983). While the state did not meet these early projections, it did remain a strong force in the renewable energy market. In 1991, 99-percent of global, utility-scale solar generation facilities were located within California (CEC, 1992).

The driving force behind California's dominance in RE has been state policies that provide incentives for homeowners and utility providers to move towards renewable energy. During the late 1970s and early 1980s, California instituted over 20 renewable energy policies including tax incentives, solar access protection, and a variety of research and development projects (Weil, 2009). This early creation of pro-renewable policies slowed during the late 1980s and early 1990s due to an increasingly contentious political atmosphere and a reduction in the price of natural gas compared to renewable technologies (Weil, 2009). This trend continued during the years following the passage of $A B 1090$ that deregulated the electricity utilities in the state.

It is possible that this shift away from RE would have continued if conditions had remained stable. However, following the 2001 California energy crisis with its rolling black outs and energy shortages, the state returned to a focus on renewable energy as an important part of energy policy. The ambitious California Renewable Portfolio Standard (RPS), created by Senate Bill 1078 in 2002, set the highest renewable energy targets in the nation for utility companies (CEC, 2011a). The original RPS standard required that 33-percent of energy procurement was to 
come from RE sources by 2020. The California Public Utility Commission (CPUC) is responsible for monitoring compliance with this standard. In 2013, California's three largest utility companies provided 22.7-percent of their retail electricity through RE (CPUC, 2015).

Besides the RPS standard, the CEC in the 2003 Energy Action Plan identified renewable energy as the preferred method to meet future state energy needs (CEC, 2003). This document outlines an aggressive strategy for encouraging renewable energy development with the goal of reaching the RPS standard by 2010 . To do this, the CEC created "market price benchmarks, standard contract terms, flexible compliance and penalty mechanisms, and bid ranking criteria under the "least cost-best fit" rubric" (CEC, 2003, p. 6).

California has continued to propose and enact legislation aimed at simplifying the development process for RE power plants to help meet the RPS standard. In 2011, Governor Jerry Brown signed several pieces of legislation to this end including the Renewable Energy Siting Act that expanded the ability to pay a fee to the Department of Fish and Game in lieu of developing traditional mitigation strategies for the impact of proposed RE project to state-listed endangered and threatened species (Grueneich et al., 2011). Another piece of legislation that affected RE development is AB 900, the Jobs and Economic Improvement through Environmental Leadership Act of 2011. This legislation streamlines and limits California Environmental Quality Act (CEQA) legal challenges, which have often been used to challenge RE and other project construction (Groom \& Chan, 2011; Roth, 2014; Sahagun, 2014; Woody, 2011). Governor Brown also signed into law Senate Bill 267, the Renewable Energy Project Ware Supply Assessments Act, which exempts photovoltaic and wind energy developments from a water supply assessment if the project requires less than 75 acre-feet of water per year (Grueneich et al., 2011).

Additional programs have encouraged renewable energy development through rebates and tax incentives (CEC, 2011a). Many of these policies focus on creating a distributed energy system through small to medium sized RE installations by businesses and individual homeowners. The Feed-in Tariff (FIT) program is an example of such policies. Originally enacted by Assembly Bill 1969 in 2006, FIT allowed for RE facilities of up to 3 MW to contract 
with utility providers to export energy into the grid. The original FIT program replaced by the AB 1969 version in 2013.

\section{Potential for Renewable Energy Development in the State}

The policies enacted over the last several years recommit the state to leading the renewable energy switch. As of June 30,2010, there were 939 facilities in the state with a renewable energy portfolio designation (CEC, 2011a). By 2013, 57 percent of the global solar energy installations for the year were within the state (Sherwood, 2014). This trend will only continue as Governor Brown seeks to raise the RPS goal to $50 \%$ by 2030 and as climate change becomes an increasing focus of public policies.

California has tremendous potential for RE power development. According to the CEC, the state has the technical potential for 1.8 million MW above the currently developed 10,000 MW of production (CEC, 2011b). This estimate includes wind, solar, geothermal, hydroelectric resources. See Table 2.1 for specific potential by resource. Of these resources, solar energy, both concentrating and photovoltaic, represents the largest potential at 18,061,362 MW or 99 percent of all RE potential in the state (CEC, 2011c). The majority of this potential is located in southeastern California in the Mojave Desert and Central Valley areas. Figures 2.2 and 2.3 provide a visual of the areas of solar potential in the United States.

\section{Trends in Solar Development in the State}

As the RPS rises, solar energy will remain an important component for utility companies seeking to remain compliant due to the large growth potential for this resource in the state. Concentrating solar power (CSP) projects have historically dominated the utility scale solar developments proposed and approved in the state, but this may change as PV increases in efficiency and decreases in price (Dinçer, 2011; Jackson \& Oliver, 2000). The CEC reviewed nine CSP projects in 2010 representing 4,180 MW of energy production and local California jurisdictions approved approximately 300 additional MW of PV projects (CEC, 2011a). Development will likely continue to increase based on the previous studies, indicating that RE will continue to make inroads on 
energy generation (Baratta, 2011; Jacobson \& Delucchi, 2011; Resch et al., 2008; Wiser, Barbose, \& Holt, 2011)

Currently, solar projects are concentrated in the southeastern portion of the state, in and near the Mojave Desert, and with a cluster of projects in the Central Valley area. These areas are likely to remain the prime areas for solar power development due to the high amounts of solar radiation they receive. See Figure 2.5 for a map of current power plant locations from the CEC.

\section{$2.3 \quad$ SOLAR TECHNOLOGIES}

Utility scale solar developments are based on two main technologies: photovoltaic (PV) and concentrating solar power (CSP), also known as solar thermal. These two technologies differ in how they convert solar energy into electrical energy. PV directly changes solar energy to electricity within PV cells, while CSP uses the thermal energy from sunlight in a thermodynamic process for production of electricity (Azoumah, Rambe, Tapsoba, \& Thiam, 2010). This difference leads to vastly different forms of infrastructure between the two technologies.

Table 2.1 California's Renewable Energy Potential (CEC, 2011c)

\begin{tabular}{|l|c|}
\hline \multicolumn{2}{|c|}{ California's Renewable Energy Potential } \\
\hline & Technical Potential (MW) \\
\hline Biomass & 3,820 \\
\hline Geothermal & 4,825 \\
\hline Small Hydro & 2,158 \\
\hline Solar (total) \\
\hline Concentrating Solar & $1,061,362$ \\
\hline Photovoltaic & $17,000,000$ \\
\hline Wave and Tidal & 3,2763 \\
\hline Wind (total) & 3,400 \\
\hline On-shore & 75,400 \\
\hline Off-shore & $18,183,728$ \\
\hline Total Technical Potential & \\
\hline
\end{tabular}




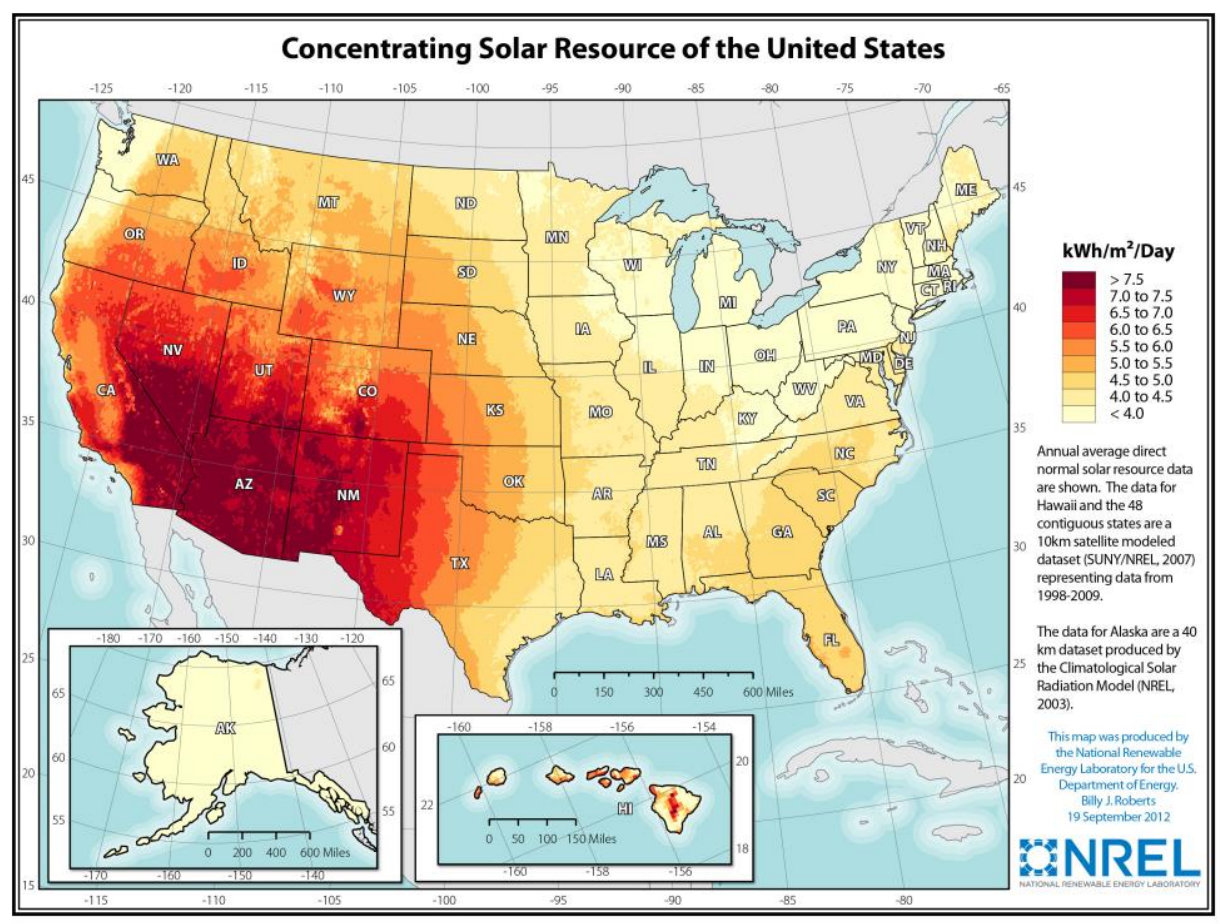

Figure 2.3 Concentrating Solar Resource of the United States (NREL, 2010a)

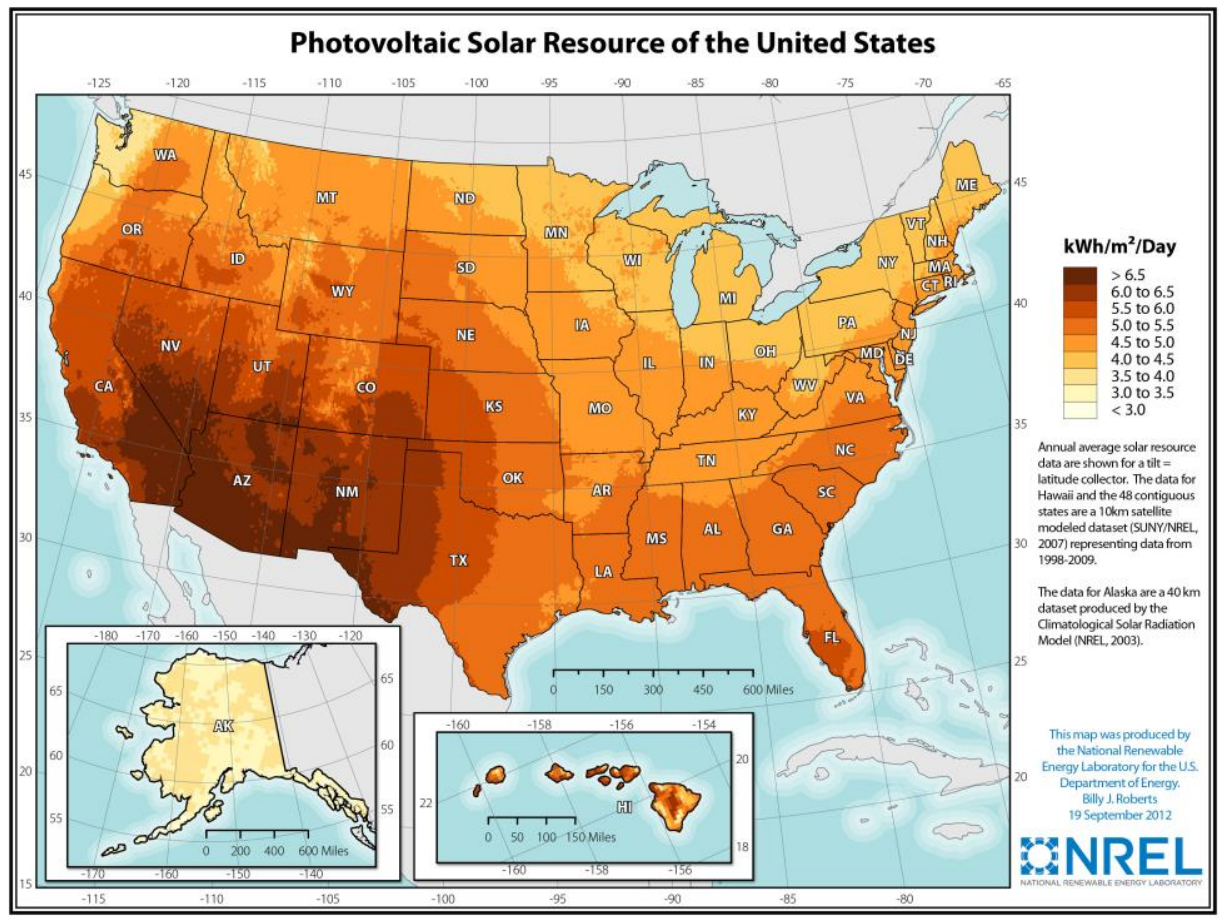

Figure 2.4 Photovoltaic Solar Resource of the United States (NREL, 2010b) 


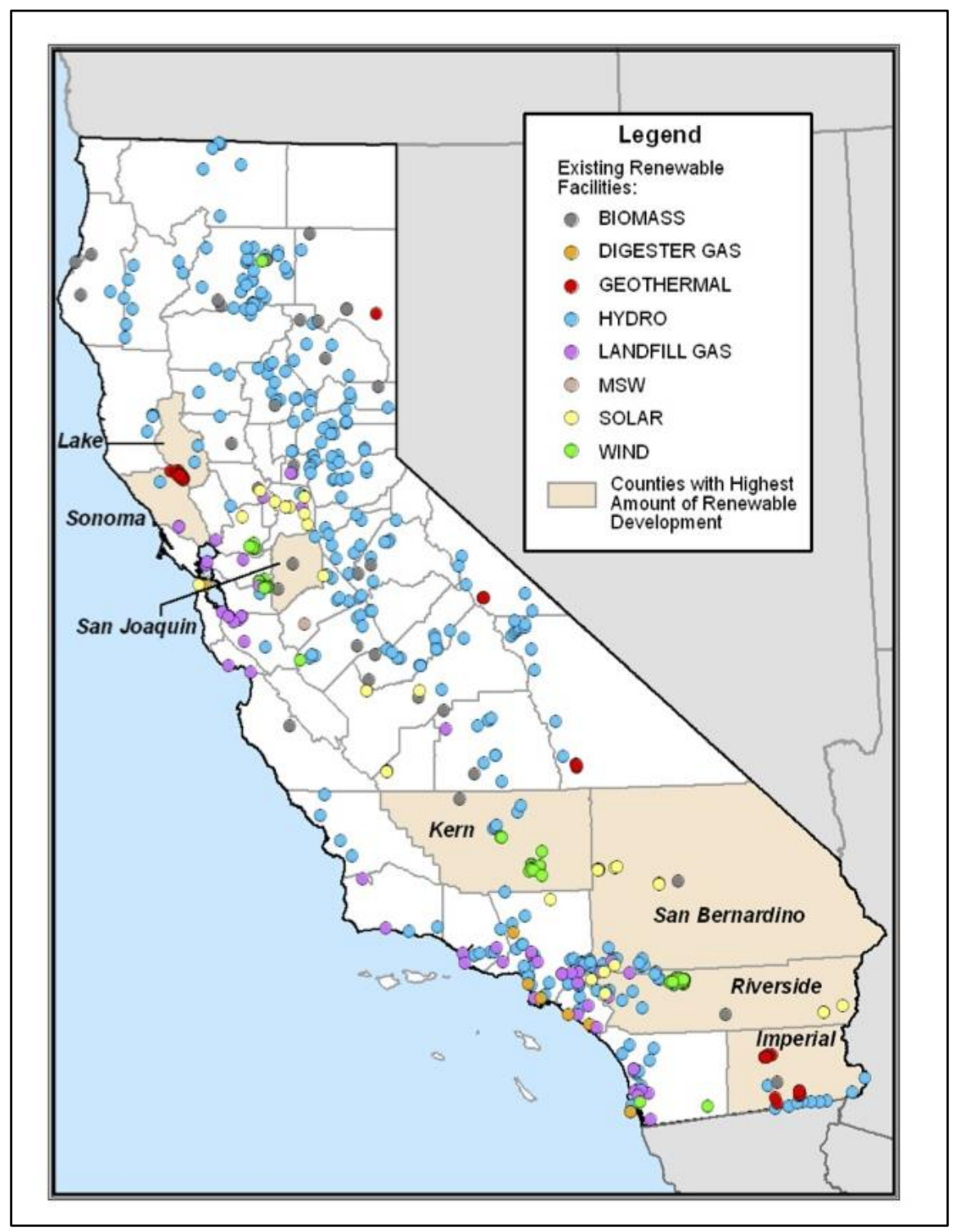

Figure 2.5 Existing Renewable Facilities in California (CEC, 2011c, p. 40) 


\section{Photovoltaic Systems}

PV systems are comprised of cells with light absorbing qualities that use solar radiation to produce free electrons that are used to create voltage (Hosenuzzaman et al., 2015). The generation capacity of a PV development is directly related to the efficiency of the PV cells, the design of the system, and the amount of solar radiation available (Chiabrando et al., 2009). There are two main types of cells, crystalline silicone and thin film, which can be further broken down into specific types (Hosenuzzaman et al., 2015). These cells are organized into modules, and the modules are arranged into arrays. The arrays are installed generally around one meter above ground on a flat site (Turney \& Fthenakis, 2011). During operation, the cells are periodically cleaned to remove accumulated dust that can impair energy absorption. Cleaning is generally accomplished with water at a rate of approximately 500-1000 gallons per megawatt peak (MWp) of panels per year (Turney \& Fthenakis, 2011). With large projects, this can lead to a significant water requirement. Figure 2.6 shows an example of a photovoltaic development.

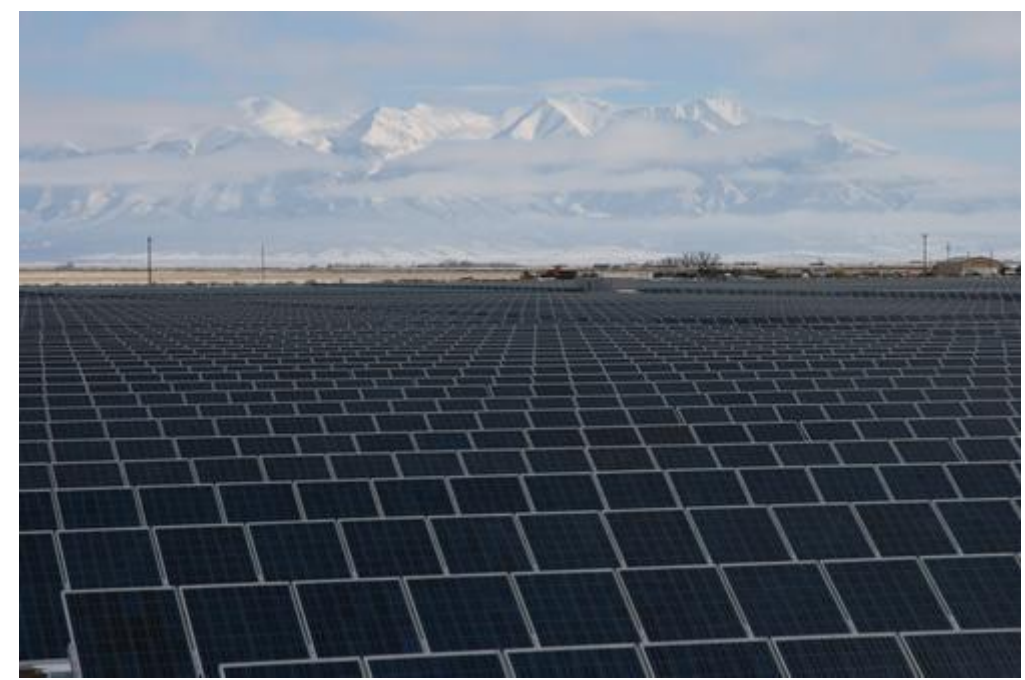

Figure 2.6 Example of a photovoltaic development (SOLAREIS, 2015)

Historically, the main barriers to PV power plant development and construction were the efficiency and cost of the PV cells compared to other technologies. In recent years, the price for cells has fallen while the efficiency has increased, which may lead to an increase in proposed PV developments (Dinçer, 2011; Hosenuzzaman et al., 2015; Jackson \& Oliver, 2000). However, the 
PV supply chain remains complex, making clear cut predictions on the effect of price changes difficult to predict (Hosenuzzaman et al., 2015).

\section{Concentrating Solar Power}

CSP projects use mirrors to reflect light onto specialized receivers in order to heat the receiver to between 400-1000 degrees Celsius (Desideri, Zepparelli, Morettini, \& Garroni, 2013). Solar thermal systems "consist of a large reflective surface collecting the incoming solar radiation and concentrating it onto a solar receiver with a small aperture area" (Romero \& GonzálezAguilar, 2014, p. 43). Reflectors are curved around one axis where the solar beams are focused to transfer heat to a fluid (Mills, 2004).

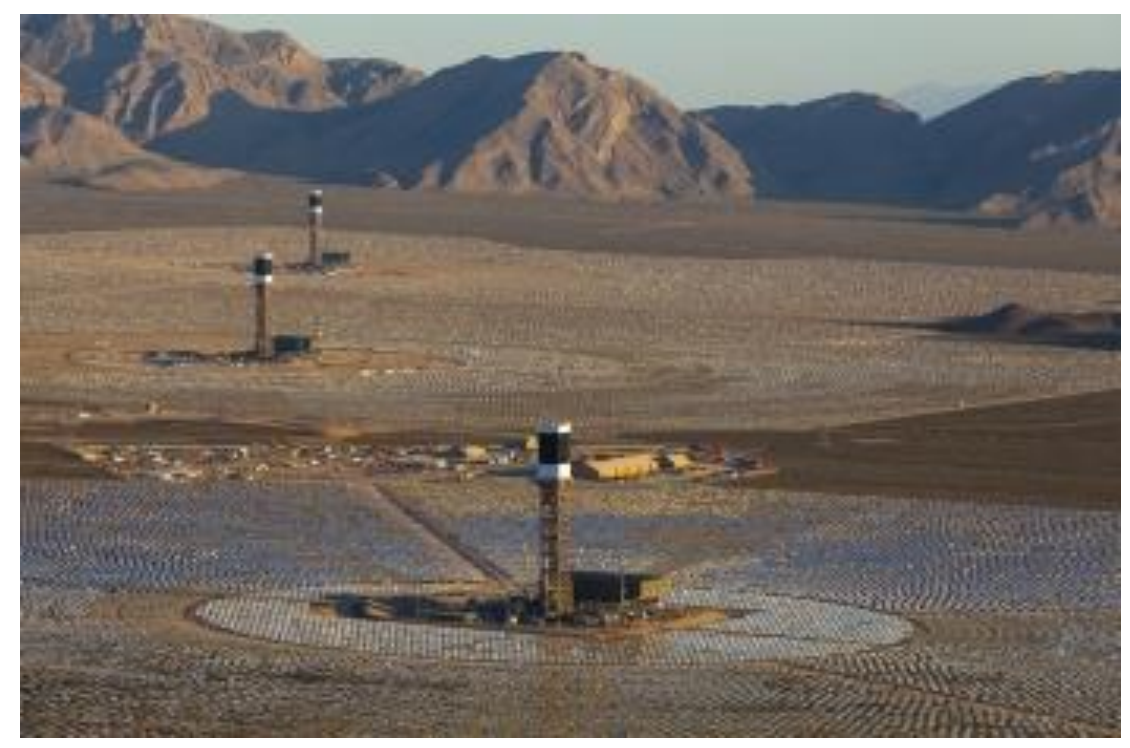

Figure 2.7 Example of a CSP development (Mingasson, 2015)

The majority of projects are designed using parabolic trough technology in which parabolic mirrors arranged in arrays around the receiver or the power tower design where sun tracking reflectors (heliostats) focus light on the main tower. In both technologies, the reflectors heat the fluid, generally water, synthetic oil, or a molten salt, in the receiver (Desideri et al., 2013). In designs using oil and salt, the heat from these liquids is used to create steam. In the receivers where the liquid is water, the steam is generated directly. The steam is then used to turn a 
turbine generator to produce electricity (Desideri et al., 2013). The arrays are installed above the ground on a flat site. The receiver, depending on site conditions, may be in the center of the mirror field or simply the focus point of the mirrors. The receiver itself is generally a tower several hundred feet tall either centered in the field of arrays or at the reflection's focal point. The water requirements for CSP projects can be significant since, in addition to the water used to clean the mirrors, the towers require water to generate steam. The amount of water required can range between 1,500-3,000 L/MW per hour. See Figure 2.7 for an example of a CSP development.

\section{$2.4 \quad$ LANDSCAPE IMPACTS}

Locating a site for a renewable energy facility, particularly large scale wind or solar power plants, cannot be regarded as a simple geographic exercise due to the impacts on the surrounding landscape (Chiabrando et al., 2009). Impacts include visual intrusion, plant degradation, ecosystem disruption, loss of arable land, land use change, and glare (Chiabrando et al., 2009; Tsoutsos, Frantzeskaki, \& Gekas, 2005; Turney \& Fthenakis, 2011). While authors note that the impacts for wind facilities exceed that of both CSP and PV installations due to the large size and inability to effectively mitigate the visual effects of the large turbines, both CSP and PV have significant consequences on the local environment (Hunold \& Leitner, 2011; Tsoutsos et al., 2005; Turney \& Fthenakis, 2011).

PV and CSP technologies impact the local landscape in distinct ways due to their differing infrastructure requirements. In PV systems, the specific impacts are to land use due to the large area required for systems. These include a reduction of arable land, reduced visual aesthetics, ecosystem disruption, and health impacts (Tsoutsos et al., 2005). For CSP systems, land use, visual impacts, ecosystem disruption, particularly of birds, as well as water usage and contamination are the main changes caused by these facilities (Tsoutsos et al., 2005). It is noted, however, that the negative effects of CSP and PV plants could be minimized through proper siting and design (Tsoutsos et al., 2005).

In California, the landscape impacts of these projects is compounded by the rural and undeveloped nature of land suitable for solar developments, including portions of the Central 
Valley and the Mojave Desert, which are considered some of the best locations for solar energy developments in the world (Hunold \& Leitner, 2011). These areas have relatively low density of development, sensitive ecosystems, and small local water supplies, making it vital to properly site and design any proposed project. Of particular concern in the Mojave are endangered species such the desert tortoise and the Mohave ground squirrel. It is unclear whether mitigation is effective for protecting these species or reducing human opposition in the case of large projects (Hunold \& Leitner, 2011).

\subsection{PUBLIC ACCEPTANCE OF UTILITY SCALE SOLAR ENERGY}

While there appears to be a high level of support for renewable energy development in the abstract on a local level, the public often voices swift and strong opposition to individual projects (Swofford \& Slattery, 2010). Those in opposition are often labeled as NIMBYist (Not in My Back Yard) and dismissed from the discussion and decision making process (K. Burningham, J. Barnett, \& D. Thrush, 2006; Devine-Wright, 2011). NIMBY refers to those who contest locally unwanted land uses such as power plants, sewage plants, and similar based on their desire to avoid negative impacts to their home ground. This label is logical to describe attitudes of resistance to local projects, but supportive of the abstract ideal.

However, several authors have noted that this is an overly simplistic label to apply to opposition to renewable energy siting and that often detractors have legitimate concerns about project effects (Devine-Wright, 2011). Burningham, Barnett, and Thrush (2006, p. 7) note that while "opposition to proposed land uses is often crudely summarized as selfish or ignorant NIMBYism, empirical studies of the reasons people give for their opposition to proposed land uses tend to reveal a wide range of motivations and explanations for opposition which cannot be adequately characterized in this way". These authors go on to further state that the perception of NIMBYism may be a result of the structure of the participation and decision making process $(\mathrm{K}$. Burningham et al., 2006).

Burningham, Barnett, and Thrush also note that other authors argue that perceived NIMBYism can also stem from those in opposition questioning whether the proposed solution is 
the appropriate or best alternative to achieve the desired result (K. Burningham et al., 2006). In the case of renewable energy development, they attempt to frame NIMBYism as the solution to the energy industry conducting business as usual in the face of scarcity and expense of energy resources. The authors note that alternative solutions include energy conservation measures, but that this may "challenge industrial profits and even the existence of particular industries" (K. Burningham et al., 2006, p. 11). However, the authors also point out that this argument is weakened by the role that consumer choice affects continuing industrial production patterns (K. Burningham et al., 2006).

While wind developments have been widely studied in terms of public opinion (Jobert, Laborgne, \& Mimler, 2007; Phadke, 2011), research studies of public response to solar developments are scarce and mostly focus on the European experience with these technologies (Fleishman, De Bruin, \& Morgan, 2010; Simon, 2009). This is perhaps due to the relative recent development of large utility scale PV and CSP developments or because these projects are perceived to have fewer impacts on the landscape than wind turbines. While academic papers are rare, the news media has documented both the opposition to and the potential support for these projects, particularly in California (Anonymous, 2007; The Vote Solar Initiative, 2009; Zweibel, Mason, \& Fthenakis, 2008)

Utility scale solar developments, defined for this study as those with a generation capacity of greater or equal to 50 mega watts of power, have faced stiff public opposition within the state of California (Groom \& Chan, 2011; Hunold \& Leitner, 2011; P. Maloney, 2008; Roth, 2014; Woody, 2012). Peter Maloney, writing for the New York Times, described the resistance to large solar developments among southern California desert residents. He noted that resident opposition may stem from a wide range of sources including potential environmental effects, the large number of proposed projects, the perception of the desert as a lifeless landscape, and environmental justice concerns (P. Maloney, 2008).

A common thread in the opposition is support for renewable energy development but only in those locations needing the energy (P. Maloney, 2008). Residents perceive that the same results, solar energy production, could just as easily be reached through large rooftop solar 
installations rather than through ecosystem damaging desert installations (P. Maloney, 2008). This seems to support the assertion that Burningham, Barnett, and Thrush dismissed in their 2006 article: that some NIMBY attitudes may simply reflect concerns about the solution to a perceived societal problem, rather than the characterized knee jerk reaction.

Despite the clear media documentation of opposition, there may be an argument to be made that resistance to these projects is not as strong as it may appear in print (The Vote Solar Initiative, 2012). A study by Vote Solar, a non-profit solar advocacy group, polled southern California residents and found that "nearly four out of five citizens polled believe that the California desert is a great resource and should be used to develop solar projects" (The Vote Solar Initiative, 2012). However, as described by research on wind developments, general voiced support for development of a renewable energy facility does not preclude strong opposition to a specific project (K. Burningham et al., 2006; Devine-Wright, 2011; Phadke, 2011; Swofford \& Slattery, 2010).

\section{$2.6 \quad$ FACTORS FOR SUCCESSFUL DEVELOPMENT}

Multiple barriers to solar project development exist including socio-political, market, and community based challenges (Wüstenhagen, Wolsink, \& Bürer, 2007). Authors have sought to determine the factors that cause certain RE projects to succeed through the planning and development process while other projects fail to reach operation (Anderson, Schirmer, \& Abjorensen, 2011; Besley, 2010; K Burningham, J Barnett, \& D Thrush, 2006; Devine-Wright, 2007, 2011; Dütschke, 2011; Eltham, Harrison, \& Allen, 2008; Kontogianni, Tourkolias, Skourtos, \& Damigos, 2014; Nadaï \& van der Horst, 2010; Wolsink, 2000; Zoellner, Schweizer-Ries, \& Wemheuer, 2008). There has been research done on the range of $R E$ technologies and, while there are unique issues to each technology, there are commonalities in terms of successful projects. These can be divided into financial, governmental, and public factors. 


\section{Financial Factors}

For any development to be successful, the project must have a positive financial outlook, which for RE projects is difficult since traditionally they have been less viable than traditional energy sources (Timilsina et al., 2012). Financial barriers that can impact Californian RE development include missing market infrastructure, high investment requirements, economic viability of technology, lack of access to credit, high up-front capital costs for investors, and lack of financial institutions to support RE developments (Carlisle et al., 2015; Painuly, 2001). To overcome these issues, government policies, such as financial incentives, are required to increase the viability of $\mathrm{RE}$ relative to traditional power sources and guarantee markets through policies like the Renewable Portfolio Standard (RPS) to provide insurance for investors (Painuly, 2001). Both California and the United States have passed policies in line with these guidelines (Del Chiaro \& Gibson, 2010). These actions, according to research, should lead to a "robust, self-sufficient solar market" and provide projects the backing to succeed financially (Del Chiaro \& Gibson, 2010).

\section{Governmental Factors}

Governmental actions, policies, and procedures have a definite effect on RE development (Del Chiaro \& Gibson, 2010; Doris, Busche, Hockett, \& Loring, 2009; Taylor, 2008; Wiser et al., 2011). However, three government factors stand out in the research for successful projects: streamlined regulations, efficient development and approval process, and transparency (Martin \& Rice, 2015; Zoellner et al., 2008). Streamlined regulations and an efficient process both serve to improve project viability by reducing the time a project is in development which decreases costs and uncertainty (Martin \& Rice, 2015; Painuly, 2001). Transparency, both in requirements, approvals, and information, serves to encourage public trust in the project (Carlisle et al., 2015; Zoellner et al., 2008). In California, the extent that these factors are met varies greatly across jurisdictions and from project to project. The California planning processes are detailed below. 


\section{Public Factors}

Despite the public acceptance and approval of RE projects in general, there is often opposition to specific projects. This "social gap" has been a significant area of research as early projects failed to take this dichotomy into account, often leading to failure ((Bell et al., 2005; van der Horst, 2007). Five primary public factors for successful projects can be identified from this research: public involvement in a fair process, a sensitivity to visual impacts, an awareness of place attachment, and a focus on the positive community impacts (Carlisle et al., 2015; Cowell, Bristow, \& Munday, 2011; Devine-Wright, 2007; Kontogianni et al., 2014; Wolsink, 2000;

Wüstenhagen et al., 2007; Zoellner et al., 2008). While it is often easy to dismiss public concerns such as NIMBYism, there are often valid reasons for local opposition to a proposed project (Bell et al., 2005; Devine-Wright, 2007; van der Horst, 2007). Taking into account public viewpoints, including concerns on changes to the landscape and the sense of place, in a process that allows these ideas to influence project outcome greatly improve the chance of success (Carlisle et al., 2015). A focus on the economic benefits, added jobs, increase in revenue, and other positive factors for the local community will also endear the project to the community (Carlisle et al., 2015).

\subsection{SOLAR POWER PLANT PUBLIC PLANNING APPROVAL PROCESS}

In the state of California, jurisdiction over a solar power plant is determined by the size and type of technology proposed in the development. CSP plants over $50 \mathrm{MW}$ in size are subject to CEC and the United States Bureau of Land Management (BLM) review. To streamline the process, these two agencies have entered a Memorandum of Understanding that outlines a joint process for these projects to follow (CEC, 2007). Photovoltaic projects, regardless of size, are subject to the planning agency with jurisdiction over the proposed development site. Generally based on the rural nature of the proposed sites, this will be a California county jurisdiction. In all cases, once the project is approved it may still be subject to litigation due to environmental concerns or other actionable issues. 


\section{California Energy Commission Process}

The CEC public planning and siting process is the application for certification that is equivalent to and replaces the CEQA review process for CSP projects greater than $50 \mathrm{MW}$ (CEC, 2000). The application process is the generally the same for both traditional power plants and RE projects, though there is a fast track process for CSP projects. The process is designed to take six to18 months from when the CEC deems the application complete and allows for public participation through a formalized process (CEC, 2000). The process, according to the CEC, is designed to "provide a consolidated state permit, an established timeline, an open process, and legally sound decisions" (CEC, 2006, p. 11).

The public is invited to participate either informally or formally in the CEC process. Informal participants may attend public meetings and comment on the project either orally at the meetings or in writing. However, comments cannot alone support a decision or a finding by the CEC Commissioners. Formal participation requires an application to intervene in the siting process. Interveners can be agencies, organizations, or members of the general public. If the application is granted, interveners become full parties to the process with equal rights and obligations to other parties such as the applicant and CEC staff (CEC, 2006). Interveners can provide testimony that unlike commentary can be used as a basis for a CEC decision. They can also cross-examine witnesses, place requests for information, and receive all documents (CEC, 2006). However, they are also subject to the same rules including Ex Parte communication rules and must send copies of filings to all other participants and answer data requests (CEC, 2006). Petitions for intervention must be submitted before the first pre-hearing conference, though it is recommended to apply as early as possible.

The fast track process for CSP projects is similar to the Small Power Plant Exemption (SPPE) process and is expected to take approximately twelve months compared to $12-18$ for a normal CEC siting process (See Figure 2.8 for the SPPE process; CEC, 2006). It is comprised of six phases: pre-filing, filing, discovery, analysis, hearing, and decision. The fast track process does not remove any procedural requirements from the process but simply expedites the phases (CEC, 2006). The public is primarily involved in the discovery, analysis, and hearing phases, 
though may also be involved in the pre-filing phase if there are public workshops. The Energy Commissioners make the final determination on project approval based on the formal testimony and data for the project, and construction on the project must commence within 12 months of approval (CEC, 2006).

\begin{tabular}{|c|c|c|c|c|c|}
\hline PURPOSE: & \multicolumn{5}{|c|}{ EXEMPT FROM STATE'S POWER PLANT SITING PROCESS } \\
\hline QUALIFYING PROJECT: & \multicolumn{5}{|c|}{ ANY THERMAL POWER PLANT 50 - $100 \mathrm{MW}$} \\
\hline QUALIFYING CRITERIA: & \multicolumn{5}{|c|}{$\begin{array}{l}\text { 1. NO SUBSTANTIAL ADVERSE ENVIRONMENTAL IMPACT } \\
\text { 2. NOT SIGNIFICANTLY IN EXCESS OF THE DEMAND FORECAST }\end{array}$} \\
\hline TYPICAL TIME: & \multicolumn{5}{|l|}{ SIX MONTHS } \\
\hline PHASE: & PREFILING & DISCOVERY & ANALYSIS & HEARING & DECISION \\
\hline TIME (MONTHS): & 0 & 2 & 4 & 5 & 6 \\
\hline \multirow[t]{3}{*}{ ACTIVITY/PRODUCTS: } & $\square$ WORKSHOPS & $\begin{array}{l}\square \text { WORKSHOPS } \\
\square \text { DATA } \\
\text { REQUEST }\end{array}$ & $\begin{array}{l}\text { STAFF } \\
\text { ANALYSIS }\end{array}$ & $\square$ HEARINGS & $\begin{array}{l}\square \text { PROPOSED } \\
\text { DECISION } \\
\text { DECISION }\end{array}$ \\
\hline & & $\begin{array}{l}\text { INFORMATION } \\
\text { HEARING }\end{array}$ & $\square$ WORKSHOPS & & \\
\hline & & $\square$ SITE VISIT & $\begin{array}{l}\square \text { INITIAL } \\
\text { STUDY }\end{array}$ & & \\
\hline
\end{tabular}

Figure 2.8 California Energy Commission Small Power Plant Exemption Process (CEC, 2006, p. 17)

Public participation in the county planning process is less formalized than in the CEC process. Interested community members can attend and speak in public meetings and workshops as well as provide commentary on draft documents. There is no distinction between testimony and commentary as in the CEC process and there is no restriction on the use of public comments. Public comments should be documented and addressed in the final EIR document.

As there is no standard process from county to county, the timeframe for approval can vary greatly based on procedure as well as political interest. One of the main factors in determining process length and cost is whether the project will need to complete an EIR. The public process begins with a permit application to the appropriate jurisdiction's planning department. If the project does not require an EIR due to either a negative declaration or a 
mitigated negative declaration, the project moves onto an administrative approval process such as the planning commission or board of supervisors. See Figure 2.9 for a sample county planning process.

Otherwise, a notice of preparation (NOP) for a draft EIR is released and is followed by a public comment period. This notice may be released at the same time as the initial application was filed or later if the determination for environmental review did not occur prior to filing. After comments are collected and reviewed, the draft EIR is completed. This may include public meetings and workshops. Once completed, the draft is submitted for public comments and then these are reviewed and answered. The draft, comments and revisions are reviewed and, if approved, the project moves onto the planning approval process including public hearings and workshops. If the planning authorities approve the project, construction must start before the permit expires which varies from county to county. See Figure 2.10 for an example of the EIR approval process. 


\begin{tabular}{|c|c|c|}
\hline \multicolumn{3}{|c|}{ Initial Planning Review } \\
\hline \multicolumn{2}{|c|}{ Determine Filing Completness } & 7-10 Days \\
\hline \multicolumn{3}{|c|}{ Planner Review } \\
\hline $\begin{array}{l}\text { Case Studies and Need for } \\
\text { Special Studies }\end{array}$ & Optional Prelimary Meetings & $30-60$ days \\
\hline \multicolumn{3}{|c|}{ Submittal of Revisions and Special Studies } \\
\hline Engineering Reports & $\begin{array}{l}\text { Environmental Assessment } \\
\text { Initiated }\end{array}$ & 30 days \\
\hline \multicolumn{3}{|c|}{ Environmental Review Initial Study } \\
\hline Decision on Negative Declaration & $\begin{array}{l}\text { Determination of Environmental } \\
\text { Impact Report Required }\end{array}$ & $7-10$ days \\
\hline \multicolumn{3}{|c|}{ Environmental Impact Review Draft } \\
\hline Scoping Meetings & Public Review & $60-90$ days \\
\hline \multicolumn{3}{|c|}{ Environmental Impact Review Approval } \\
\hline Community Workshops & Determination of Adaquacy & 45 days \\
\hline \multicolumn{3}{|c|}{ Final Review } \\
\hline Staff Report & Public Hearings and Resolution & $40-75$ days \\
\hline
\end{tabular}

Figure 2.9 Sample County Planning Process Adapted from Riverside County Development Process (Riverside County Planning Department, 2015) 


\section{Project Requires An Environmental Impact Report (EIR)]}

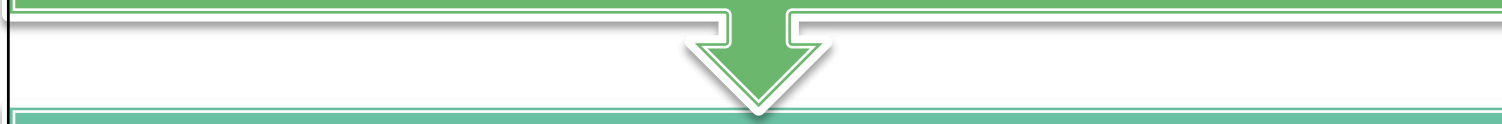

\section{Scoping of EIR}

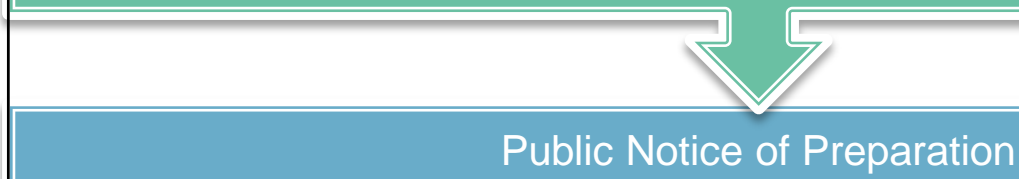

\begin{tabular}{cc} 
Publish & $\begin{array}{c}\text { Reviw and Transmit } \\
\text { Comments }\end{array}$ \\
\hline
\end{tabular}

Develop Guidelines for the Determiniation of Significance and Methodolgies

Develop Draft EIR

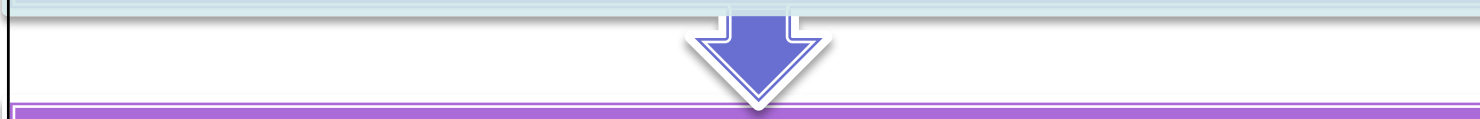

\section{Public Review of Draft EIR}

\begin{tabular}{|c|c|c|c|}
\hline Publish Draft & Public Review & $\begin{array}{l}\text { Respond to } \\
\text { Comments }\end{array}$ & $\begin{array}{l}\text { Recirculate and } \\
\text { Revise as Needed }\end{array}$ \\
\hline \multicolumn{4}{|c|}{ Finalize CEQA Documentation } \\
\hline \multicolumn{2}{|c|}{ Review Findings } & \multicolumn{2}{|c|}{ Develop Staff Reports } \\
\hline \multicolumn{4}{|c|}{ Final Decision } \\
\hline Hearing Prepa & nd Attendance & Pro & cision \\
\hline
\end{tabular}

Figure 2.10 Sample EIR Process Adapted from San Diego County EIR Flowchart (County of San Diego Department of Planning and Land Use Regulatory Planning Division, 2003) 


\section{CHAPTER 3: METHODOLOGY}

\subsection{PROJECT RATIONAL}

Within the state of California, there are two main planning processes a utility scale solar project may be subject to depending on technology type and location: California Energy Commission (CEC) application for certification or local county planning approval. Utility scale solar projects are defined for this discussion as those with a proposed generation capacity of 50 MW or greater. The CEC holds jurisdiction over concentrating solar thermal (CSP) projects with of $50 \mathrm{MW}$ or greater capacity, which is the basis for the definition of utility scale solar for this paper (CEC, 2007). Photovoltaic (PV) projects are subject to the local county planning approval process. To date, there has been no comparative analysis published on these two different processes. This may be due to the lack of sufficient data in a usable format or it not being aggregated in a single database. The objective of this project is to provide a database with that information and to provide some initial qualitative analysis of the data.

Prior to this project, no comprehensive list of utility scale solar projects in the State of California was compiled. Partial or specialized lists exist, developed primarily by government agencies tracking their own, or related, projects or industry associations. The CEC and the Solar Energy Industries Association (SEIA) maintain the two primary databases found during research for this project. However, these lists have limitations that make them unsuitable for research on the state of large-scale solar development in the state.

The currently available project databases suffer from several limitations including narrow focus, inaccessibility, or insufficient data. Many databases focus on a small subset of all the projects in the state. For example, the CEC database provides information only on projects within their jurisdiction, CSPs greater than $50 \mathrm{MW}$ in size. Likewise, many local counties maintain databases of proposed projects in their area and potentially surrounding counties, but no data on projects across the state (County of San Bernardino Land Use Services and Planning Division, 2015; Kern County Planning Department, 2013). Other databases, such as the SEIA database, are inaccessible to the general public. Access to the SEIA database requires organization membership (SEIA, 2015). Many of the databases have insufficient data to provide a basis for 
research analysis and are primarily a list of project names, acreage, capacity, and status (County of San Bernardino Land Use Services and Planning Division, 2015).

The CEC maintains a listing of all solar thermal projects that have started the application for certification process (CEC, 2012b). The list itself provides minimal data: project name, location, lead agency, size and technology, and status. Additional information is found through the links the list provides to the individual project application sites, where the documentation for the project application is stored. The project documentation includes all planning documents, responses from information requests from all official project participants, public comments, and transcripts of public meetings. However, the focus of this database is extremely narrow and unable to provide a complete understanding of solar development in the state due to the lack of inclusion of PV projects.

In comparison, the Solar Energy Industries Association, a US trade organization focused on the solar industry, has a frequently updated large list of projects that it develops based on "public announcements of solar projects in the form of company press releases, news releases, and, in some cases, conversations with individual developers" (SEIA, 2015). This list is more comprehensive in nature but is primarily made available only to SEIA members in a database format. A PDF is available on their website but limits the ability of the public to search and compile information in a usable format to look at projects only in their state or area. It may also miss projects that are not self-reported or widely publicized.

Other lists of projects exist in many other locations with varying coverage, updates, and focus. Local and county governments and planning departments often maintain lists of relevant projects to their jurisdictions (County of San Bernardino Land Use Services and Planning Division, 2015; Kern County Planning Department, 2013). Project proposals and environmental review documentation often include partial lists of projects that are either precedents or in nearby jurisdictions in order to explain project context or cumulative impact ("Desert Renewable Energy Conservation Plan Environmental Impact Report: Cumulative Impacts Analysis," 2014; ESA, 2012). These lists focus on renewable energy or solar projects in a limited geographical scope and provide few details such as project name, size, or capacity. Lobbying and environmental 
groups maintain or publish lists of projects of interest to their specific groups (SEIA, 2015). While these lists are useful for the organizations creating and publishing them, they are not good research tools for academics and planners looking for a broader picture of development.

\subsection{COMPLICATIONS TO CREATING DATABASE}

There were many complications to creating a comprehensive list of utility scale solar projects in California. These included fragmented data, lack of readily available information, unclear data, and out of date information. These issues often highlighted issues with the development process, such as litigation or politically controversial projects, but more than anything reinforced the need for a comprehensive database.

One complication was fragmented data. While there is a large amount of data available on projects, it is widely dispersed across multiple agencies, developers, and organizations. Many projects only appeared in one location or list, with no further information found after extensive searching. Fragmented data slowed compilation. Often many days were spent back tracking projects through web searches or determining that there was not sufficient data for inclusion on the final list for analysis. However, in most cases, the issue was finding the information in multiple locations and then creating a cohesive picture of the state of a project.

The lack of readily available information was often unavoidable. Many projects are still in between completion of the planning process and the start of construction. Others are in litigation, or became too controversial to continue. In some cases, information may be proprietary to the development company. Sometimes the most information that could be found on a controversial project was a series of continuations at Board hearings followed by nothing, leaving no indication whether the project was completely abandoned or on hold. Other projects were announced in an industry or newspaper article but never began the public process. The lack of conclusive data on unfinished projects complicates determining the factors in their failure.

In many cases, if the data was available, it was unclear. This, in particular, hampered determination of project ownership and project status. Determining absolute ownership was 
often impossible due to subsidiary companies or company name changes. Likewise, project status was often obscured by not only a lack of updates but also by conflicting messages.

\subsection{PRIMARY SOURCES}

The initial basis for this thesis was the databases maintained by the CEC, the SEIA, and the California Renewable Energy Action Committee (REAT). Of the project lists found in the initial research stages, these were the most comprehensive and up to date.

The CEC database provided information only on solar thermal projects that were either in the process of certification or had attempted certification (CEC, 2014). This included projects that switched technologies either to or from solar thermal during their development process. Along with the list of projects, the CEC site also maintains a public database of all project documents for each application for certification, which provided many of the additional details for these projects.

The SEIA database is a nationwide database of projects developed from public announcements and interviews (SEIA, 2015). The searchable database is only available to SEIA members; however, there is a PDF version free to the public. For this research, the PDF was converted to an Excel format in order to facilitate separating the California projects from the rest of the nation. The information provided by the SEIA database is more limited in scope compared to the CEC database, requiring further project information to be gleaned from additional Internet searches.

The REAT database is second to the SEIA in creating a comprehensive list of non-solar thermal projects in the state (CEC, 2013). As with the SEIA list, it is constrained in the amount of information provided with only the project name, county, developer, size, and technology type listed. More in-depth research was required for a full profile of the named projects.

\subsection{DATABASE TOPICS}

Determination of which subjects to compile in the database was an important facet of this research. There are limitless topics that could provide interesting and relevant results to understanding how projects of this nature are developed in California. However, due to time and 
data limitations the topics and subjects needed to be restricted. Database topics and subjects were chosen based on general project characteristics, factors relevant to the California Renewable Portfolio Standard (RPS), from a literature review of factors influencing project acceptance and approval, and topics related to public approval process.

\section{Base Topics}

The base database topics were chosen primarily from general project characteristics. The base topics are project name, ownership, and power purchaser agreement. These factors represent the basic facts for each project, though not every project is expected to have a power purchase agreement. Table 3.1 provides the rational for choosing each base topic and Appendix A shows the base topics database.

\section{Table 3.1 Rational for Base Topics}

\begin{tabular}{|l|l|}
\hline \multicolumn{2}{|c|}{ Rational for Base Topics } \\
\hline Project Name & General Characteristic \\
\hline Ownership & $\begin{array}{l}\text { General Characteristic } \\
\text { Literature Review }\end{array}$ \\
\hline Transfer of Ownership & General Characteristic \\
\hline Power Purchaser & RPS Interest \\
\hline Project Status & General Characteristic \\
\hline
\end{tabular}

Projects are identified by their project names in most planning review and public hearing documentation. In the case of a name change, it was important to identify both the original and the final names to compile all project information. Name changes may reflect changes in technology or an attempt to rebrand a project after ownership change or controversy.

Project ownership and transfer of ownership may play an important role in project trajectory as each company has a differing technology focus as well as relationships with the public which was found in the literature to be an important factor in public acceptance for individual projects (Carlisle et al., 2015; Cowell et al., 2011; Devine-Wright, 2007; Kontogianni et 
al., 2014; Wolsink, 2000; Wüstenhagen et al., 2007; Zoellner et al., 2008). The ownership of most projects is extremely fluid as one company may be responsible for handling the approval process, another for the construction, and another for the operation. Ownership may also be confused by the use of subsidiary companies under the heading of a larger corporation. Ownership information was found either through planning documentation or newspaper and industry articles.

Power purchase agreements are contracts between an electricity generator and a buyer, generally a utility company. They are not a required component of the planning process for solar projects but play an important role for utility companies seeking RPS compliance. By contracting with renewable energy $(\mathrm{RE})$ companies who are developing these projects, the utility companies are able to increase the proportion of RE energy in their portfolio. Planning documentation, newspaper or industry articles, or publicly available contracts were the source for power purchase agreement details.

Project status provides a snapshot of the current state of the proposed project. For the purposes of this project, there are eight potential statuses: canceled, in litigation, on hold, operating, under construction, under development, under review, and under revision. The definition for each status is listed in Table 3.2. It is often difficult to determine when a project has been canceled, as many projects never finish the approval process and simply linger in the review process. These projects are listed in this database as in review, though they may be

functionally canceled. Status information was determined through a variety of sources including planning commission meeting minutes, CEC notifications, and newspaper and industry articles.

\section{Location Topics}

Location plays an important role in any development and an even larger role in RE and solar developments. Multiple authors note that the RE developments are limited in location based on the availability of RE resources on the project site (Baratta, 2011; Gatrell \& Jensen, 2009; Pimentel et al., 2002; Resch et al., 2008). Project concentration in or near a location may also affect public acceptance for a new project, particularly if the local residents will not receive 
the benefits of the development (P. Maloney, 2008). Location information was found in the environmental review documents, or requests for zoning changes. Table 3.3 lists the location topics and their rational and Appendix B provides the location topics database.

\section{Technology Topics}

The technology topics were chosen primarily due to their effect on the public approval process and as general project characteristics. However, they are also supported by research on public acceptance for RE projects. The factors are original and current project technologies, switch from CSP/PV, and generation capacity. Table 3.4 provides the rational source for the technology topics and Appendix $\mathrm{C}$ shows the technology topics database.

\section{Table 3.2 Project Status Definitions}

\begin{tabular}{|l|l|}
\hline \multicolumn{2}{|c|}{ Project Status Definitions } \\
\hline Canceled & Project canceled \\
\hline In Litigation & Project in litigation \\
\hline On Hold & Project is on hold (CEC status) \\
\hline Operating & Fully constructed and operating \\
\hline Under Construction & Active construction \\
\hline Under Development & Prior to public review process \\
\hline Under Review & In public review process \\
\hline Under Revision & Under going revision in review \\
\hline
\end{tabular}

Table 3.3 Rational for Location Topics

\begin{tabular}{|l|l|}
\hline \multicolumn{2}{|c|}{ Rational for Location Topics } \\
\hline County & $\begin{array}{l}\text { General Characteristic } \\
\text { Literature Review }\end{array}$ \\
\hline Nearest City & $\begin{array}{l}\text { General Characteristic } \\
\text { Literature Review }\end{array}$ \\
\hline
\end{tabular}


Table 3.4 Rational for Technology Database Topics

\begin{tabular}{|c|l|}
\hline \multicolumn{2}{|c|}{ Rational for Technology Database Topics } \\
\hline Original Technology & $\begin{array}{l}\text { Public Approval } \\
\text { Literature Review }\end{array}$ \\
\hline Current Technology & $\begin{array}{l}\text { Public Approval } \\
\text { Literature Review }\end{array}$ \\
\hline Switch from PV/CSP & $\begin{array}{l}\text { Public Approval } \\
\text { Literature Review }\end{array}$ \\
\hline Generation Capacity & $\begin{array}{l}\text { General Characteristic } \\
\text { RPS Interest }\end{array}$ \\
\hline
\end{tabular}

${ }^{*} \mathrm{PV}$ : Photovoltaic

${ }^{*}$ CSP: Concentrating Solar Power

The choice of CSP and PV technology determines the public approval process, generation capacity, and the potential public acceptance of a project. In California, the jurisdiction for the public planning approval process for a utility scale solar project is determined first by technology type, then by location. If a project uses CSP technology, it falls under CEC jurisdiction. If a project is proposed using PV technology, the project is subject the county planning process where the proposed site is located. The visual and environmental impacts of these technologies differ greatly as well, potentially affecting public opposition to an individual project (Tsoutsos et al., 2005).

Projects that switch technologies during the approval process face a longer approval process due to the change in jurisdiction. Increased process time was recognized as a potential factor in projects failing to reach completion during the literature review and is an important factor to consider in these cases (Martin \& Rice, 2015; Painuly, 2001). Technology information was found in project documentation or industry notices.

Generation capacity is both a general project characteristic, indicated by its inclusion on most project lists found during initial research, RPS requirements, and based on research on project acceptance. Generation capacity is affected by the technology of the project, the solar radiation received in the area, and project size. Larger projects generate more power and require substantial amounts of land. The landscape change required by these projects is noted as a factor affecting opposition to a project (Chiabrando et al., 2009; Tsoutsos et al., 2005; Turney \& Fthenakis, 2011). Additionally, generation capacity is of interest to the RPS in order to meet the 
$33 \%-50 \%$ RE generation required by the statute. Generation capacity was primarily found in planning documents or in project news releases.

\section{Land Use Topics}

Land use topics focus on the original site characteristics and the size of the proposed development. These represent both basic project characteristics, particularly in terms of site size, as well as recognized factors in the literature for acceptance. Table 3.5 lists the land use topics, definitions, and rational for their inclusion while Appendix D provides the database for the land use topics.

The size of the solar projects examined in this project requires significant investments of land area ranging from hundreds to thousands of acres. Increasing the size of the project may have a negative effect on public support due to an increase in environmental, visual, and cultural impacts (Chiabrando et al., 2009). Project size was found in environmental review documentation, zoning requests, or news releases.

Table 3.5 Rational for Land Use Topics

\begin{tabular}{|l|l|l|}
\hline \multicolumn{2}{|c|}{ Definitions and Rational for Land Use Topics } \\
\hline & Definition & Rational \\
\hline Land Ownership & Public or Private Land & Literature Review \\
\hline Original Land Use & Original Site Zoning & Literature Review \\
\hline Total Site Acreage & Entire Project Site & $\begin{array}{l}\text { General Characteristic } \\
\text { Literature Review }\end{array}$ \\
\hline Developed Site Acreage & Developed Site & $\begin{array}{l}\text { General Characteristic } \\
\text { Literature Review }\end{array}$ \\
\hline
\end{tabular}

\section{Jurisdiction Topics}

Utility scale solar projects are not subject to a uniform planning process in the state of California. It is therefore important to examine how the success of the projects is determined by jurisdiction. Jurisdiction is determined by the technology of the project followed by the location of the project. CSP proposals greater than $50 \mathrm{MW}$ in size fall under the CEC certification process 
while PV projects are subject to the site's local county planning process. Besley (2010) notes the importance of a fair and involved planning process to public acceptance of individual projects. Table 3.6 lists the jurisdiction topics and rational while Appendix E provides the jurisdiction topics database.

Table 3.6 Rational for Jurisdiction Topics

\begin{tabular}{|l|l|}
\hline \multicolumn{2}{|c|}{ Rational for Jurisdiction Topics } \\
\hline Jurisdiction at Initiation & Public Approval \\
\hline Current Jurisdiction & Public Approval \\
\hline
\end{tabular}

\section{Process Topics}

Process topics focus primarily on the planning documentation the project was required to complete. In the case of the CEC process, all projects are subject to the same steps and requirements including a full environmental review process. The county process is much more variable as the California Environmental Quality Act (CEQA) allows jurisdictions leeway in determining the amount of environmental review a project is subject to. A county may require the completion of an initial study and environmental impact report (EIR) or move directly into the EIR. Local agencies may also allow projects to complete a shorter process through the use of a mitigated negative declaration. As large-scale solar projects can create massive landscape and environmental change on the development site, understanding how the environmental review process has been applied to the projects may provide insight on both approval and completion of construction (Chiabrando et al., 2009; Webler \& Tuler, 2000). Table 3.7 shows the rational for the process topics and Appendix $E$ has the database for process topics.

An initial study provides a method to determine whether a project will need a full environmental impact report. It is not required to be completed and, often in the case of large projects, is skipped in favor of starting a full EIR. In cases where a full EIR is not required, the initial study process may be the best chance for public involvement in the project beyond appearing at planning commission meetings. In the case of CEC projects, the process requires a 
full EIR; therefore an initial study is not necessary. Initial study information was found through public notices and planning documentation.

\section{Table 3.7 Rational for Process Topics}

\begin{tabular}{|l|l|}
\hline \multicolumn{2}{|c|}{ Rational for Process Topics } \\
\hline CEQA/NEPA Initial Study Completed & Public Approval \\
\hline EIS/EIR Required & $\begin{array}{l}\text { Public Approval } \\
\text { Literature Review }\end{array}$ \\
\hline Negative Declaration & $\begin{array}{l}\text { Public Approval } \\
\text { Literature Review }\end{array}$ \\
\hline Approval Status & General Characteristic \\
\hline
\end{tabular}

The EIR process is an in-depth look at the impacts a project may have on the surrounding environment including visual, environmental, plus air and water quality. It involves significant public involvement and review. As public involvement has been shown to improve the public acceptance of projects, the requirement to complete an EIR may improve project success (Gross, 2007; Webler \& Tuler, 2000). However, the EIR process is considered to be an expensive and uncertain process for developers, which may hinder project proposals (Barbour \& Teitz, 2005; Olshansky, 1996). EIR data was found through public notices and planning documentation.

Mitigated negative declarations are often used as a streamlined environmental review process by local jurisdictions due to their lower cost and shorter public involvement (Barbour \& Teitz, 2005). However, these may be subject to litigation if substantial evidence is found that the declaration was issued arbitrarily and capriciously (Varner, 1991). As noted previously, project acceptance is also predicated on a publically perceived fair and open process which may be adversely affected by the quick timeframe of the mitigated negative declaration process (Gross, 2007; Webler \& Tuler, 2000). Negative declaration information was found through public notifications and planning documentation. 
Approval status describes the current status of the project in the public review process.

For this project, there are four potential statuses: in process, no, yes, and unknown. The definition for each status is found in Table 3.8. The approval status for projects was found through planning documentation, planning commission meeting minutes, and newspaper articles.

Table 3.8 Approval Status Definitions

\begin{tabular}{|l|l|}
\hline \multicolumn{2}{|c|}{ Approval Status Definitions } \\
\hline In Process & In the Review Process \\
\hline No & Project Not Approved \\
\hline Yes & Project Approved \\
\hline Unknown & Unknown, Process Not Started \\
\hline
\end{tabular}

\section{Process Time Topics}

Process time is often cited as a negative to project completion by developers and industrial advocates while the public may appreciate longer processes (Barbour \& Teitz, 2005; Hall, Ashworth, \& Devine-Wright, 2013; Martin \& Rice, 2015). In order to compare time spent in the public review process, dates were chosen from the initial public review meeting based on the determined public process. The first notice of preparation or initial public notice was chosen as the initial start date for the public process time. The approval or disapproval of the highest review committee such as the planning commission or the county board of supervisors determined the public review end point. This may not truly be the end of the public process due to litigation and appeals but it serves as the end of the general planning process. The dates were found in planning documents or through newspaper articles on the status of a project. Table 3.9 provides the process time topics and rational and Appendix $F$ has the data for the process time topics. 
Table 3.9 Rational for Process Time

\begin{tabular}{|l|l|}
\hline \multicolumn{2}{|c|}{ Rational for Process Time Topics } \\
\hline Public Process Used for Dates & $\begin{array}{l}\text { General Characteristic } \\
\text { Public Approval }\end{array}$ \\
\hline Total Process Time & Public Approval, Literature Review \\
\hline Public Review Start & General Characteristic \\
\hline Public Review End & General Characteristic \\
\hline
\end{tabular}

\section{Construction Topics}

Project approval is the first step in creating a fully functioning solar power plant. After approval, a project must start construction before the approval expires after facing potential protests and litigation. Due to the complexities of completing a project, the construction data is the least complete section of the database. It is an attempt to understand how many of the proposed projects have begun or completed construction. Completed projects are of particular interest when viewed through the RPS as they increase the RE capacity in the state. This data was the most difficult to find with the primary sources being newspaper or industry news releases. Most projects either had no information on construction status or have not begun construction. Table 3.10 shows the construction topics and rational and Appendix $G$ has the construction topics database.

\subsection{CRITERIA FOR DATABASE INCLUSION}

Due to the complications in creating the database, not every project found was included in the final database. To be included, a project needed to have more than the base data of project name, owner, and location. Projects were not required to have started the public process but there needed to be sufficient documentation to determine technology, generation capacity, jurisdiction, and site size. 
Table 3.10 Rational for Construction Topics

\begin{tabular}{|l|l|}
\hline \multicolumn{2}{|c|}{ Rational for Construction Topics } \\
\hline Construction Start & $\begin{array}{l}\text { General Characteristic, } \\
\text { RPS Interest }\end{array}$ \\
\hline Estimated Online Date & $\begin{array}{l}\text { General Characteristic, } \\
\text { RPS Interest }\end{array}$ \\
\hline Online Status & $\begin{array}{l}\text { General Characteristic, } \\
\text { RPS Interest }\end{array}$ \\
\hline Online Start Date & General Characteristic \\
\hline Complete Online Date & $\begin{array}{l}\text { General Characteristic, } \\
\text { RPS Interest }\end{array}$ \\
\hline
\end{tabular}




\section{CHAPTER 4: ANALYSIS}

Prior to this research, no comprehensive database of large-scale solar projects existed for the state of California. There was also little to no published qualitative research completed on comparing the California Energy Commission (CEC) application for certification process and the local county planning processes. Analysis of the final database was conducted to determine the current state of utility scale solar project development in the state, while also comparing project details for CEC and county projects. Additional analysis was completed to identity trends in California solar development to determine how the industry is changing over time.

\subsection{BASIC PROJECT NUMBERS}

The final database includes a total of ninety-five total projects. Eighty projects had sufficient data for analysis. Eighteen of these projects were proposed as solar thermal, and sixtyone were proposed as photovoltaic systems. Five projects switched from solar thermal (CSP) to photovoltaic (PV) technology during the planning process. The public process environmental review process is complete for forty-eight projects, with forty-six receiving approval. Eighteen projects started construction, and six projects are complete. See Table 4.1 for list of basic project numbers and Figure 4.1 for a view of number of projects by county.

In terms of original jurisdiction, 56 projects were under local county planning control, the CEC had sole jurisdiction in 13 projects, 3 projects were joint between the CEC and the BLM, and the rest of the projects were either under state control prior to the CEC process or solely in federal jurisdiction. See Table 4.2 for listing of original jurisdictions. Because 5 projects switched from solar thermal to photovoltaic (PV) technology during the planning process, the CEC has only eight projects remaining under its jurisdiction. The five projects that switched to PV moved to local county control for final public approval. See Table 4.2 for listing of current jurisdiction numbers. Figure 4.2 provides a visual comparison of the jurisdiction project numbers. 
Table 4.1 Project Numbers

\section{Project Numbers}

Total Number of Projects

Projects Proposed as Concentrating Solar Thermal (CSP)

Projects Proposed as Photovoltaic (PV)

19

Number of Projects Switched from CSP to PV

5

Number of Projects with Complete Public Process

Number of Approved Projects

Number of Projects with Construction Starts

Number of Online Projects

${ }^{*}$ CSP: Concentrating Solar Power

*PV: Photovoltaic

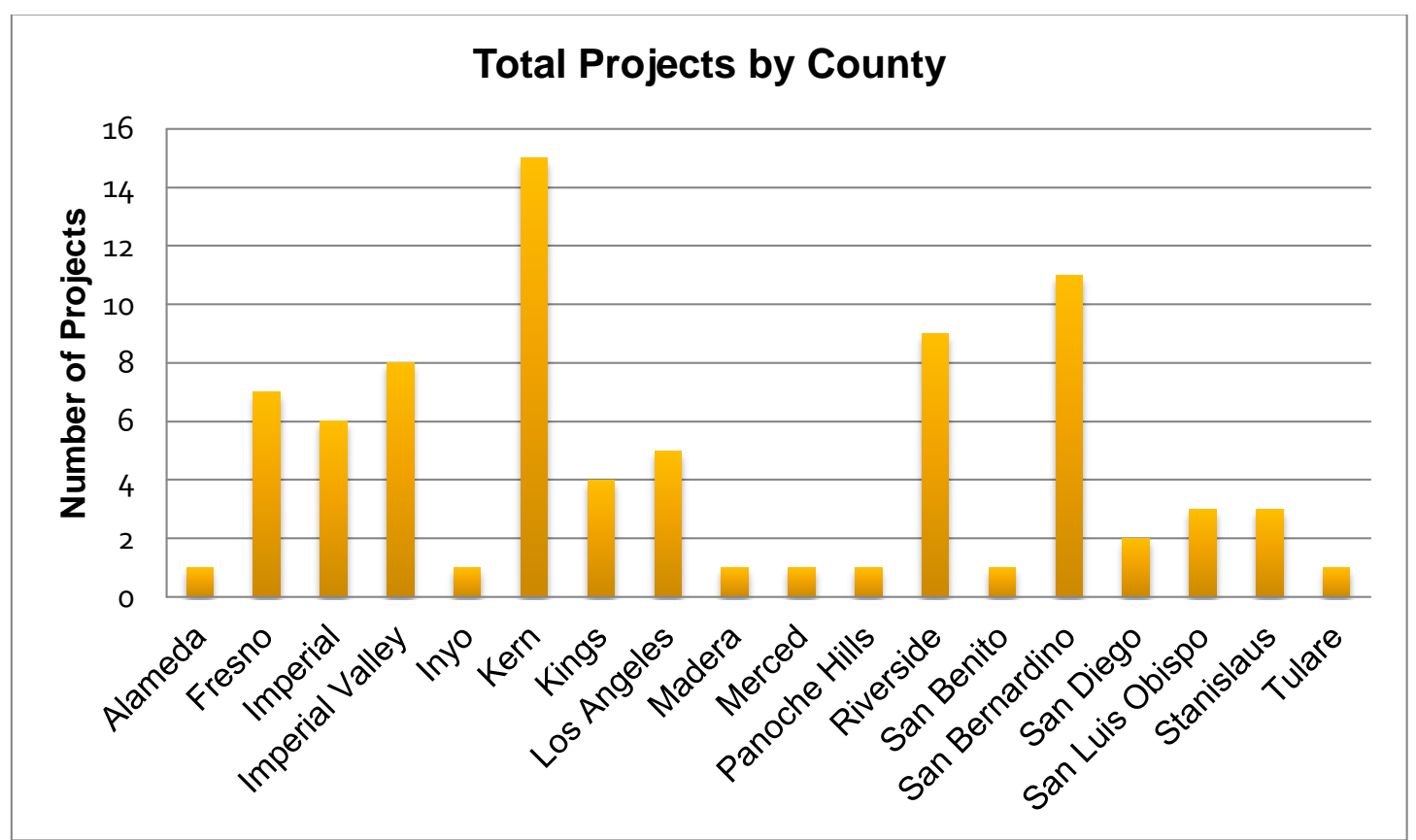

Figure 4.1 Total Projects by Count

Table 4.2 Projects by Jurisdiction

\begin{tabular}{|l|c|c|}
\hline \multicolumn{3}{|c|}{ Projects by Jurisdiction } \\
\hline & Original & Current \\
\hline Army & 1 & 1 \\
\hline Bureau of Land Management (BLM) & 5 & 7 \\
\hline California Energy Commission (CEC) & 13 & 8 \\
\hline CEC and BLM & 3 & 3 \\
\hline County & 56 & 59 \\
\hline State & 2 & 2 \\
\hline Grand Total & 80 & 80 \\
\hline
\end{tabular}




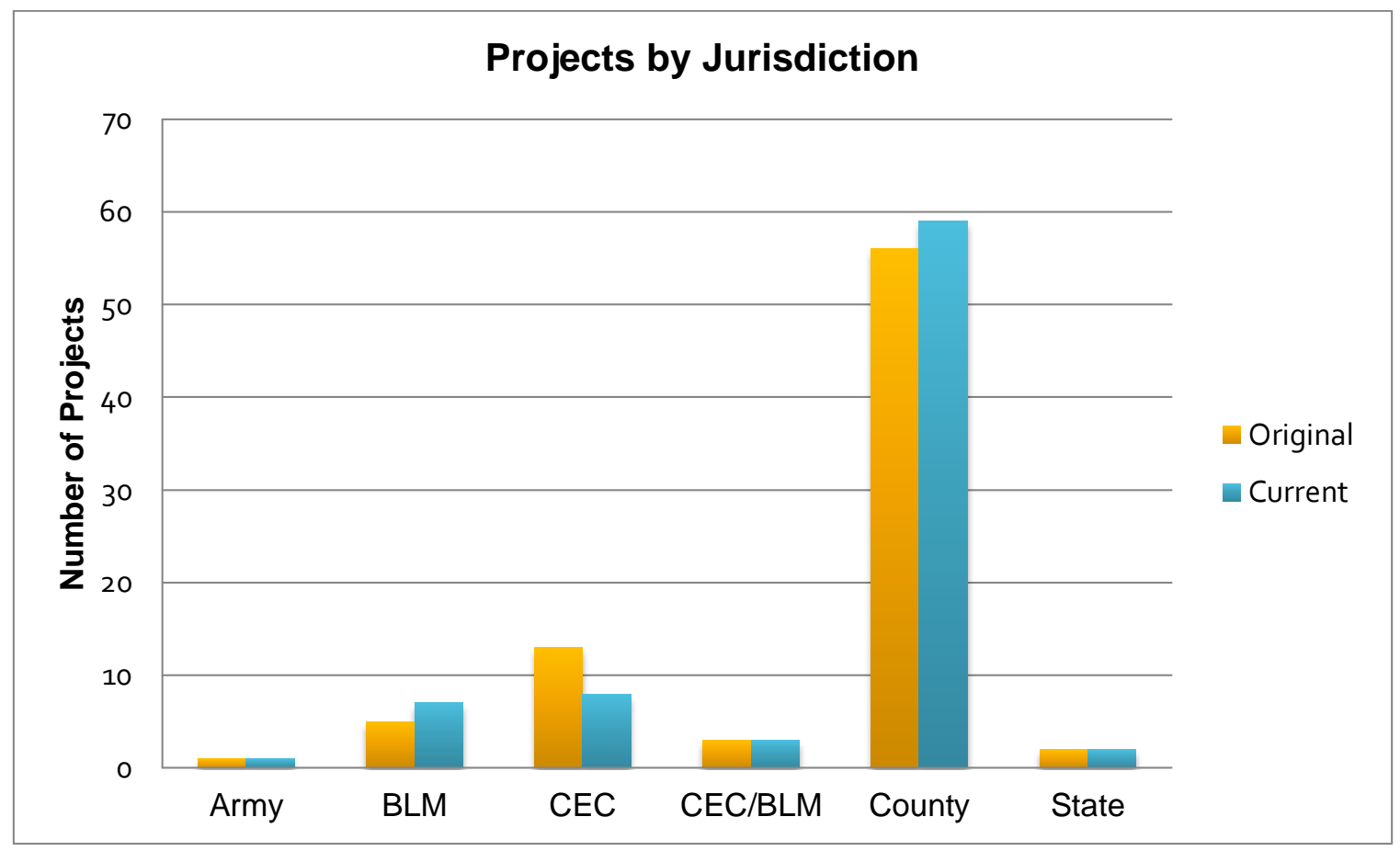

*BLM: Bureau of Land Management

*CEC: California Energy Commission

Figure 4.2 Projects by Jurisdiction

Table 4.3 Projects by Project Status

\begin{tabular}{|l|c|c|c|}
\hline \multicolumn{4}{|c|}{ Projects by Project Status } \\
\hline & Total & County Jurisdiction & CEC Jurisdiction \\
\hline Operating & 10 & 7 & 1 \\
\hline Under Construction & 8 & 6 & 2 \\
\hline Canceled & 5 & 2 & 3 \\
\hline In Litigation & 1 & 1 & 0 \\
\hline Under Revision & 2 & 0 & 2 \\
\hline Under Review & 22 & 18 & 1 \\
\hline On Hold & 6 & 1 & 3 \\
\hline Under Development & 26 & 21 & 4 \\
\hline Grand Total & 80 & 56 & 16 \\
\hline
\end{tabular}

${ }^{*}$ CEC: California Energy Commission 
Of the eighty projects, ten projects are in the operation phase either fully completed or partially complete and eight are under construction. Five projects have been canceled and at least one project is in litigation. There are two projects under revision, twenty-two in planning review, and six on hold during the planning process. Twenty-six are in development prior to entering the public review process. See Table 4.3 for project status numbers and Table 4.4 for operational status.

Table 4.4 Projects by Operational Status

\begin{tabular}{|l|r|r|r|}
\hline \multicolumn{5}{|c|}{ Projects by Operational Status } \\
\hline & Total & County Jurisdiction & CEC Jurisdiction \\
\hline No & 70 & 50 & 15 \\
\hline Partial & 4 & 3 & 1 \\
\hline Yes & 6 & 4 & 0 \\
\hline Grand Total & 80 & 57 & 16 \\
\hline
\end{tabular}

${ }^{*}$ CEC: California Energy Commission

As noted previously, forty-seven projects received approval during the planning process.

Only three projects were denied approval, one project was canceled, and four projects are on hold. Twenty-two projects remain in process. In process projects may or may not ever complete the planning process and, in some cases, may represent a passive denial of approval. See Table 4.5 for the approval status numbers.

Table 4.5 Projects by Approval Status

\begin{tabular}{|l|c|c|c|}
\hline \multicolumn{5}{|c|}{ Projects by Approval Status } \\
\hline & Total & County Jurisdiction & CEC Jurisdiction \\
\hline Approved & 47 & 34 & 9 \\
\hline Denied & 3 & 0 & 4 \\
\hline Canceled & 1 & 0 & 0 \\
\hline In Process & 22 & 21 & 1 \\
\hline On Hold & 4 & 0 & 2 \\
\hline Unknown & 3 & 1 & 0 \\
\hline Grand Total & 80 & 56 & 16 \\
\hline
\end{tabular}

${ }^{*}$ CEC: California Energy Commission 
Forty-five projects had a designated power purchase agreement. The projects with an agreement are split fairly evenly between Pacific Gas and Electric, San Diego Gas and Electric, and Southern California Edison. The US Army and the Los Angeles Department of Power and Water each have one known agreement each. See Table 4.6 for power purchaser numbers.

Table 4.6 Projects by Power Purchaser

\begin{tabular}{|l|c|c|c|}
\hline \multicolumn{4}{|c|}{ Projects by Power Purchaser } \\
\hline & Total & County Jurisdiction & CEC Jurisdiction \\
\hline $\begin{array}{l}\text { Los Angeles Department of } \\
\text { Power \& Water }\end{array}$ & 1 & 0 & 1 \\
\hline Pacific Gas \& Electric & 18 & 14 & 5 \\
\hline San Diego Gas \& Electric & 13 & 12 & 1 \\
\hline Southern California Edison & 12 & 6 & 4 \\
\hline U.S. Army & 1 & 0 & 0 \\
\hline (blank) & 35 & 24 & 5 \\
\hline Grand Total & 80 & 56 & 16 \\
\hline
\end{tabular}

${ }^{*}$ CEC: California Energy Commission

The total proposed site area for all projects encompasses 197,179 acres or approximately 308 square miles, while the developed site (land disturbed for project development) area for all projects is 175,350 acres or approximately 273 square miles. For projects within the county jurisdiction, the total proposed site area is 120,771 acres with 105,384 acres for development. CEC jurisdiction projects comprise a proposed total area of 70,202 acres and 59,128 acres developed. See Table 4.7 for site acreage numbers

The average project size varies greatly between the county and CEC jurisdictions. The overall average total project area is 2,528 acres for all projects, 2,965 acres for county projects, and 4,388 acres for CEC projects. The average developed site land area is 2,248 acres across the entire database, 2,361 acres for county specific projects, and the CEC projects have an average size of 2,942 acres. See Table 4.7 for average and median site acreage numbers and Figure 4.3 for a visual comparison of average and median site sizes by jurisdiction. 
Table 4.7 Site Acreage

\begin{tabular}{|l|c|c|c|}
\hline \multicolumn{4}{|c|}{ Site Acreage } \\
\hline & Total & County Jurisdiction & CEC Jurisdiction \\
\hline Total Proposed Site & 197179 & 120771 & 70202 \\
\hline $\begin{array}{l}\text { Total Proposed } \\
\text { Developed Site }\end{array}$ & 175350 & 105384 & 59128 \\
\hline $\begin{array}{l}\text { Average Total Site } \\
\text { Proposal }\end{array}$ & 2528 & 2965 & 4388 \\
\hline $\begin{array}{l}\text { Average Developed } \\
\text { Site Proposal }\end{array}$ & 2248 & 2361 & 3942 \\
\hline $\begin{array}{l}\text { Median Total Site } \\
\text { Proposal }\end{array}$ & 1367 & 1100 & 3362 \\
\hline $\begin{array}{l}\text { Median Developed } \\
\text { Site Proposal }\end{array}$ & 1140 & 1002 & 3324 \\
\hline
\end{tabular}

${ }^{*}$ CEC: California Energy Commission

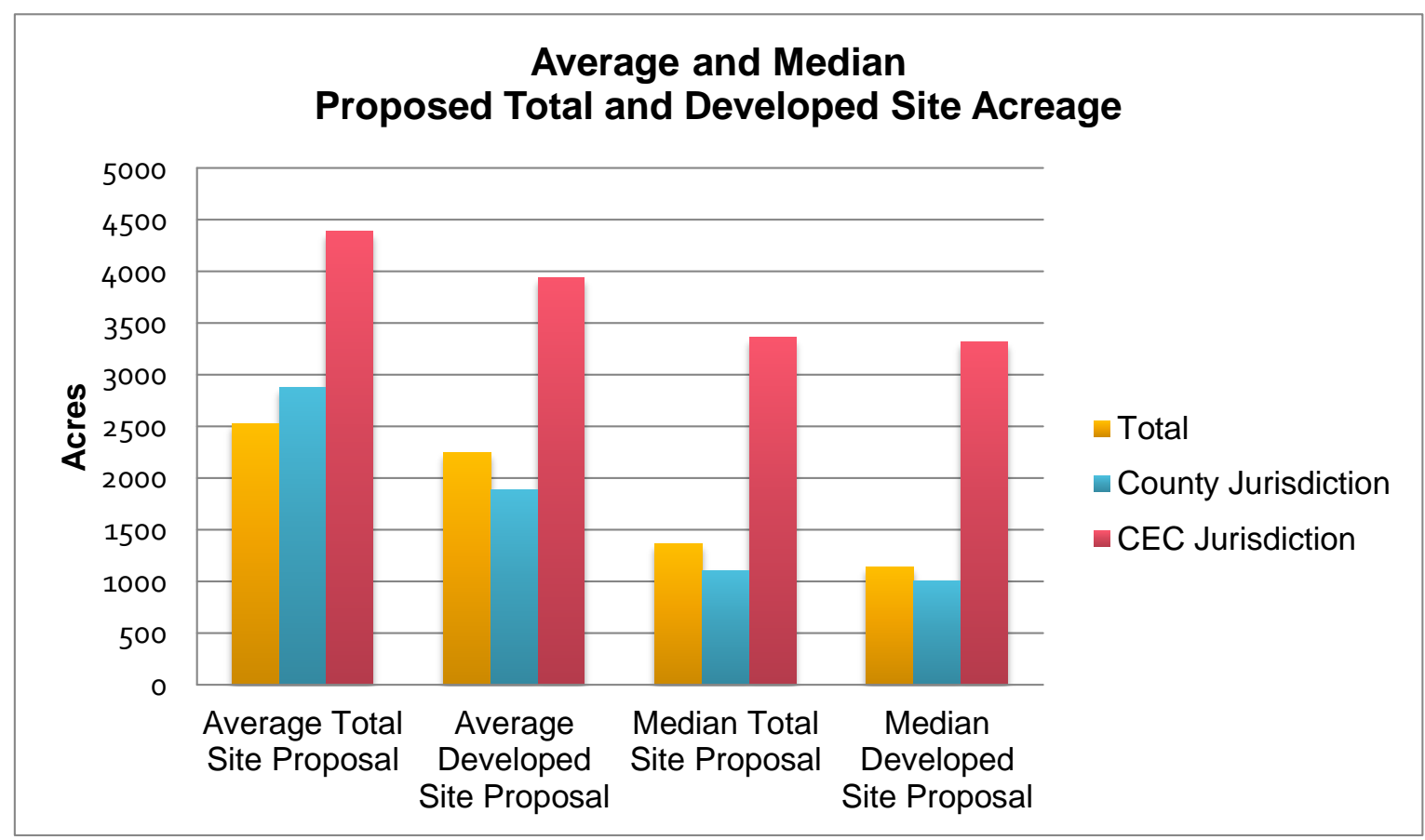

${ }^{*}$ CEC: California Energy Commission

Figure 4.3 Average and Median Proposed Total and Developed Site Acreage 
The majority of the proposed project land is zoned for agricultural uses or managed by the BLM. There are small amounts of land that were previously zoned for landfill, military and residential uses. County projects primarily were proposed on agricultural land while due to the nature of the CEC jurisdiction the majority of the original land use for their jurisdiction's proposed projects was BLM land. See Table 4.8 for the total site acreage by original land use numbers, and Figure 4.4 for graphic illustration of site acreage by original land use.

Table 4.8 Total Site Acreage by Original Land Use

\begin{tabular}{|l|c|c|c|}
\hline \multicolumn{4}{|c|}{ Total Site Acreage by Original Land Use } \\
\hline & Total & County Jurisdiction & CEC Jurisdiction \\
\hline Agriculture & 119215 & 141925 & 11764 \\
\hline BLM & 68753 & 8230 & 55114 \\
\hline Landfill & 1687 & 1687 & 0 \\
\hline Military & 3324 & 0 & 3324 \\
\hline Residential & 3200 & 6400 & 0 \\
\hline Unknown & 1000 & 0 & 0 \\
\hline Grand Total & 197179 & 158242 & 70202 \\
\hline
\end{tabular}

*BLM: Bureau of Land Management

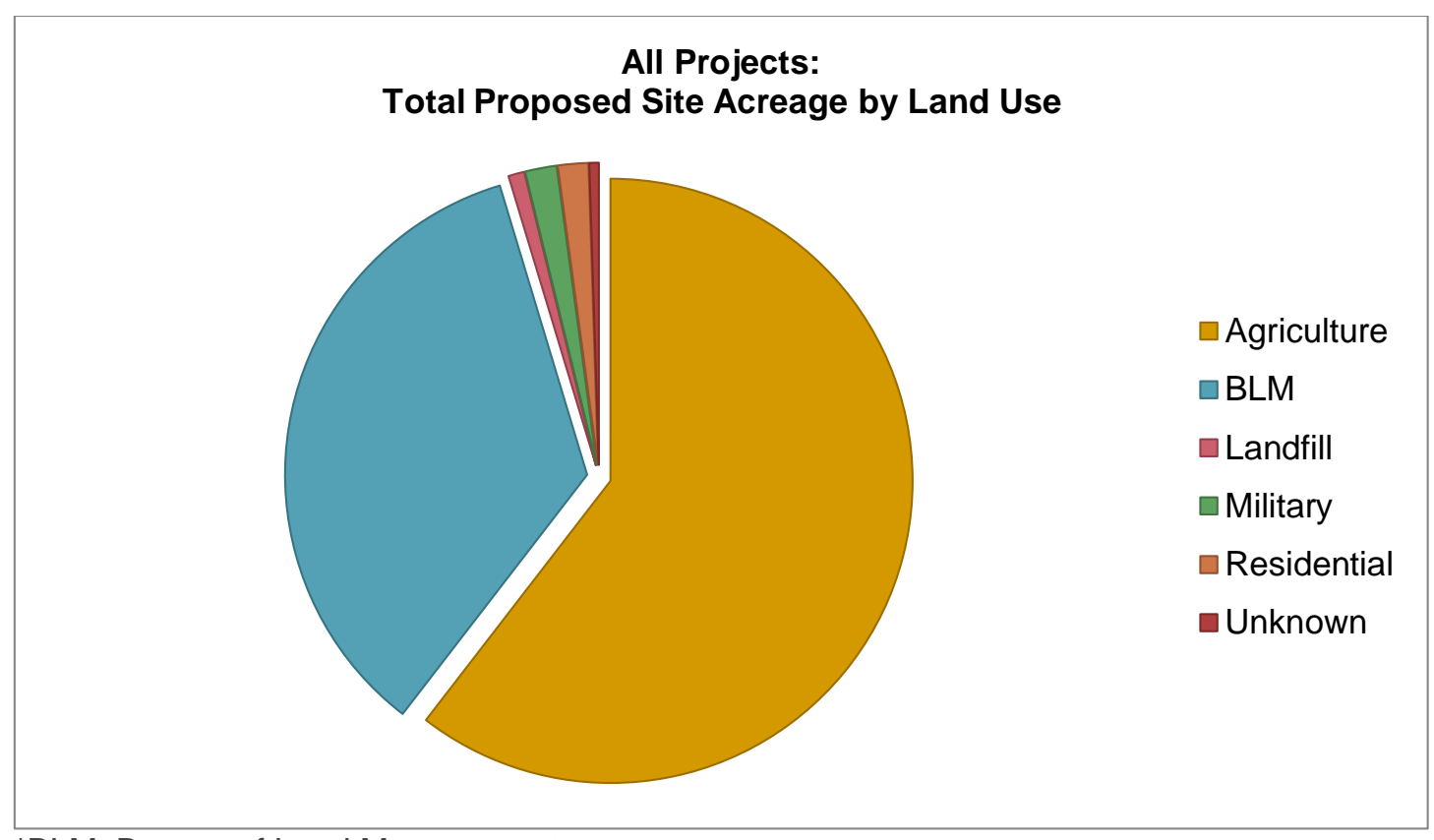

*BLM: Bureau of Land Management

Figure 4.4 All Projects: Total Proposed Site Acreage by Land Use 
The proposed generation capacity of all projects in this study is $23,313 \mathrm{MW}$, with projects in county jurisdiction contributing 17,555 MW, and 7,225 MW for CEC projects. The average generation capacity is $291.41 \mathrm{MW}$ for all projects, $307.98 \mathrm{MW}$ for county projects, and 451.56 MW for CEC projects. In comparison, the median proposed generation capacities are $160 \mathrm{MW}$ for all projects, $150 \mathrm{MW}$ for county jurisdiction, and $493 \mathrm{MW}$ for CEC jurisdiction. The variance between the average and median values for the county projects is likely due to several very large proposed county projects, while the slight difference in CEC average and median proposed generation capacity could be attributed to the low sample size for these projects. See Table 4.9 for details on the proposed generation capacity based on jurisdiction.

Table 4.9 Proposed Generation Capacity (MW)

\begin{tabular}{|l|c|c|c|}
\hline \multicolumn{4}{|c|}{ Proposed Generation Capacity (MW) } \\
\hline & Total & County Jurisdiction & CEC Jurisdiction \\
\hline $\begin{array}{l}\text { Total Proposed } \\
\text { Generation Capacity }\end{array}$ & 23313 & 17555 & 7225 \\
\hline $\begin{array}{l}\text { Average Proposed } \\
\text { Generation Capacity }\end{array}$ & 291 & 308 & 452 \\
\hline $\begin{array}{l}\text { Median Proposed } \\
\text { Generation Capacity }\end{array}$ & 160 & 150 & 493 \\
\hline
\end{tabular}

${ }^{*}$ CEC: California Energy Commission

The average public process time across all projects is 520 days or 1.42 years across all jurisdictions and technologies. The average for CSP projects, with no switch in technology, is 655 days or 1.79 years, while the average for PV is 453 days ( 1.24 years). The average time for projects that switched technology is significantly longer at 1,052 days (2.96 years). The length of process time in this category may be due to the small sample size (5), but also is likely reflective of the fact that these projects go through a second planning process. See Table 4.10 for the average process time by technology and Figure 4.5 for a visual version of this data. 
Table 4.10 Average Public Process Time by Technology

\begin{tabular}{|l|c|c|}
\hline \multicolumn{3}{|c|}{ Average Public Process Time by Technology } \\
\hline & Days & Years \\
\hline All Projects & 520 & 1.42 \\
\hline CSP (No Switch) & 655 & 1.79 \\
\hline PV (No Switch) & 453 & 1.24 \\
\hline CSP to PV Switch & 1082 & 2.96 \\
\hline
\end{tabular}

${ }^{*}$ CSP: Concentrating Solar Power

*PV: Photovoltaic

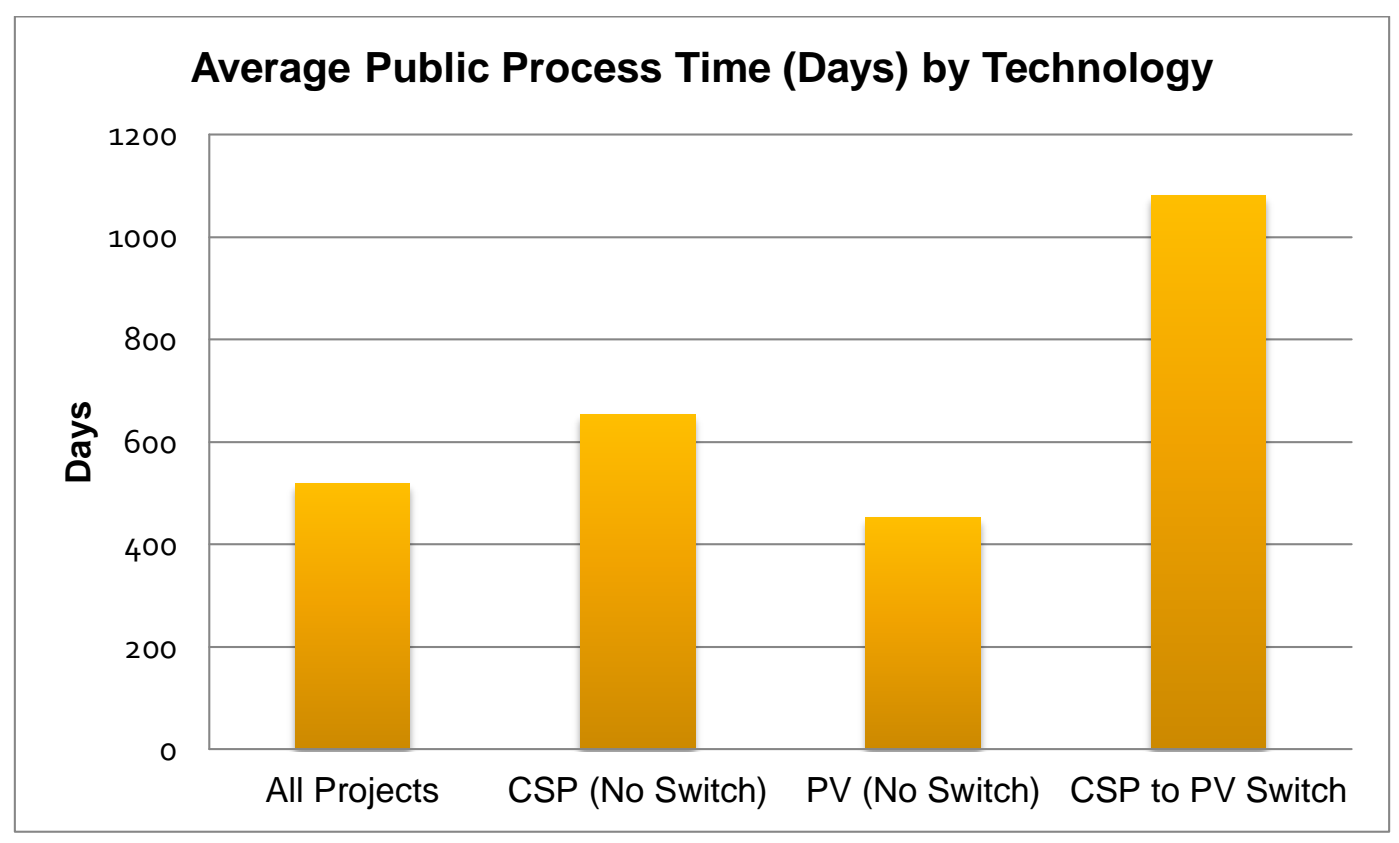

${ }^{*}$ CSP: Concentrating Solar Power

*PV: Photovoltaic

Figure 4.5 Average Public Process Time (Days) by Technology

Looking at average public process time from the perspective of jurisdiction, the average public process time for all county projects, including technology switches, is 480 days (1.42 years). For projects in county jurisdiction without a switch from CSP to PV, the average time is 388 days ( 1.06 years). In the CEC jurisdiction, the average process time for a project including those that switched technologies is 845 days ( 2.32 years) compared to 676 days or 1.85 years for those that remained CSP projects. See Table 4.11 for average public process time by jurisdiction. 
Table 4.11 Average Public Process Time by Jurisdiction

\begin{tabular}{|l|c|c|}
\hline \multicolumn{3}{|c|}{ Average Public Process Time by Jurisdiction } \\
\hline & Days & Years \\
\hline Total & 520 & 1.42 \\
\hline County Jurisdiction (including switches) & 480 & 1.31 \\
\hline County Jurisdiction (no switch) & 388 & 1.06 \\
\hline CEC Jurisdiction (including switches) & 845 & 2.32 \\
\hline CEC Jurisdiction (no switch) & 676 & 1.85 \\
\hline
\end{tabular}

${ }^{*}$ CEC: California Energy Commission

\subsection{CALIFORNIA ENERGY COMMISSION JURISDICTION}

Of the eighty total projects in the database, sixteen are or were subject to the CEC's jurisdiction. These sixteen projects include the five projects that switched technologies as they were affected by the CEC process despite ending in county jurisdiction. The sixteen projects are located in six California counties, with the majority of the proposed sites located in Riverside and San Bernardino counties (see Table 4.12). Nine projects received approval from the CEC certification process and three have started construction. The three projects that have started construction are in either Riverside or San Bernardino counties. It is also of interest to note that, while Riverside County has the largest number of projects and approvals, it still has only one construction start. See Table 4.12 for the specific county breakdown of projects, approvals and construction starts and Figure 4.6 for a graphic view of this data.

As noted earlier, the CEC projects are proposed to cover a land area of 70,202 acres. Due to the discrepancy in project numbers, Riverside and San Bernardino Counties have the largest proportion of the proposed area. Due to the small sample size, it is impossible to make any judgments on the average site size for these projects as several counties have only a single project proposed in their area. However, it is important to note that these are extremely large projects generally averaging several thousand acres. See Table 4.13 for the specific data for the total proposed, the proposed total developed, and the averaged total and developed site size area by county. 
Table 4.12 California Energy Commission Jurisdiction: Number of Projects, Approvals, and Construction Starts

\begin{tabular}{|l|c|c|c|}
\hline \multicolumn{4}{|c|}{ California Energy Commission Jurisdiction: } \\
\hline & Total Projects & Approved Projects & Construction Starts \\
\hline & 1 & 0 & 0 \\
\hline Imperial & 1 & 0 & 0 \\
\hline Inyo & 2 & 1 & 0 \\
\hline Kern & 6 & 5 & 1 \\
\hline Riverside & 5 & 3 & 2 \\
\hline San Bernardino & 1 & 0 & 0 \\
\hline San Luis Obispo & 16 & 9 & 3 \\
\hline Grand Total & \multicolumn{3}{|c|}{} \\
\hline
\end{tabular}

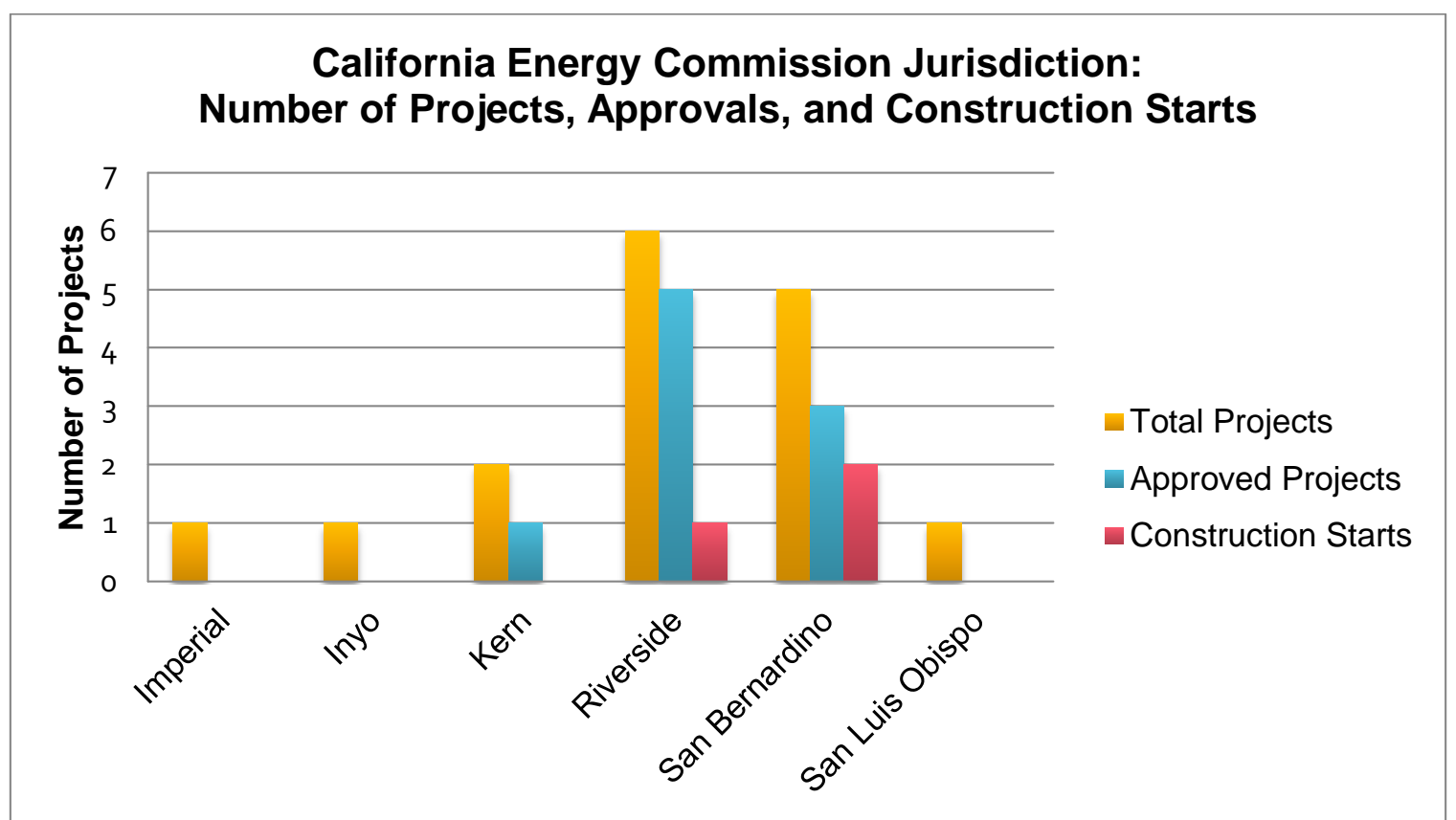

Figure 4.6 California Energy Commission Jurisdiction: Number of Projects, Approvals, and Construction Starts 
Table 4.13 California Energy Commission Jurisdiction: Site Area

\begin{tabular}{|c|c|c|c|c|}
\hline \multicolumn{5}{|c|}{$\begin{array}{l}\text { California Energy Commission Jurisdiction: } \\
\text { Site Area }\end{array}$} \\
\hline & Total Site Area & $\begin{array}{l}\text { Total Developed } \\
\text { Area }\end{array}$ & $\begin{array}{l}\text { Average Total } \\
\text { Site Area }\end{array}$ & $\begin{array}{c}\text { Average } \\
\text { Developed Area }\end{array}$ \\
\hline Imperial & 6360 & 6360 & 6360 & 6360 \\
\hline Inyo & 3277 & 3277 & 3277 & 3277 \\
\hline Kern & 6007 & 2000 & 3003.5 & 2000 \\
\hline Riverside & 33833 & 30383 & 5638.83 & 5064 \\
\hline San Bernardino & 20085 & 16468 & 4017 & 3294 \\
\hline San Luis Obispo & 640 & 640 & 640 & 640 \\
\hline Grand Total & 70202 & 59128 & 4388 & 3942 \\
\hline
\end{tabular}

When comparing the average process time by county and the number of project

approvals, there appears to be a correlation between shorter time and number of approvals (see Figure 4.7). This supports the theory that a lengthy planning process inhibits project completion due to cost to the developer (Barbour \& Teitz, 2005).However, statistically there is a very low

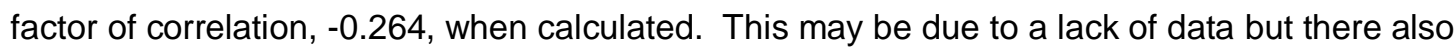
may not be a direct correlation between time and approval due to the complicated nature of the public planning process. See Table 4.14 for the average process time data and Figure 4.7 for visual comparison of average process time and project approvals.

\subsection{COUNTY JURISDICTION}

There are fifty-six projects in the database that are or were under county jurisdiction in one of the fifteen counties with proposed projects. Kern County has the largest number with fourteen projects, followed by Imperial Valley County with eight, Fresno County with seven, and Los Angeles County with five. This contrasts with the prime counties for CEC projects, which were Riverside County, and San Bernardino County. Riverside County has no proposed PV projects and San Bernardino County has two compared to six CSP projects in Riverside and five CSP projects in San Bernardino. This may be due to differences in land availability, zoning law, or environmental factors. See Table 4.15 for a breakdown of the project numbers for those in county jurisdiction. 
Table 4.14 California Energy Commission Jurisdiction: Average Public Process Time

\begin{tabular}{|l|c|c|}
\hline \multicolumn{3}{|c|}{$\begin{array}{c}\text { California Energy Commission Jurisdiction: } \\
\text { Average Public Process Time }\end{array}$} \\
\hline \multicolumn{2}{|c|}{ Days } & Years \\
\hline Imperial & 827 & 2.27 \\
\hline Inyo & 0 & 0 \\
\hline Kern & 1740 & 4.77 \\
\hline Riverside & 608 & 1.67 \\
\hline San Bernardino & 1058 & 2.90 \\
\hline San Luis Obispo & 755 & 2.07 \\
\hline Grand Total & 845 & 2.32 \\
\hline
\end{tabular}

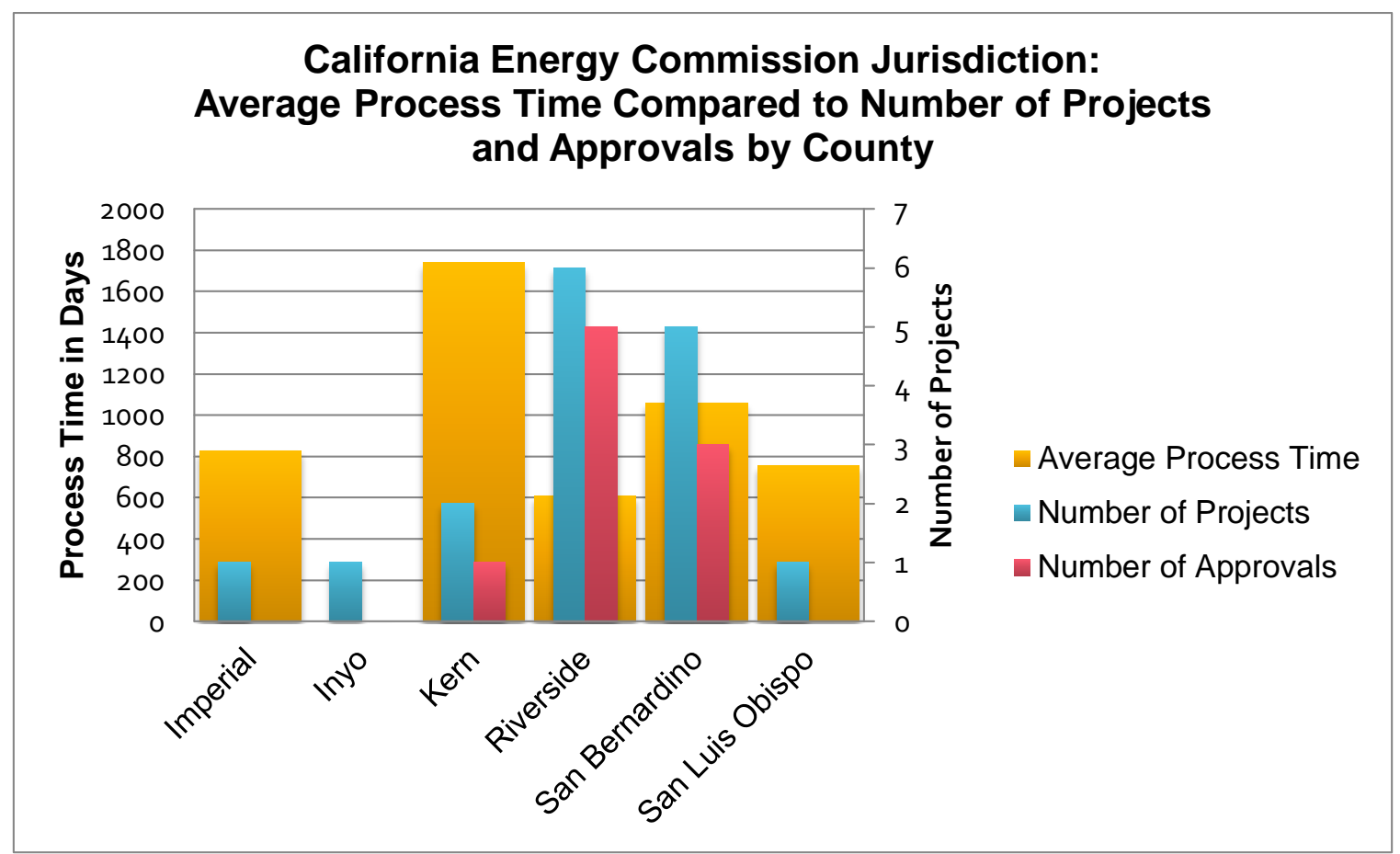

Figure 4.7 California Energy Commission Jurisdiction: Average Process Time Compared to Number of Projects and Approvals by County 
Table 4.15 County Jurisdiction: Total Number of Projects, Approved Projects, Mitigated Negative Declarations, and Construction Starts

\begin{tabular}{|l|c|c|c|c|}
\hline \multicolumn{5}{|c|}{$\begin{array}{c}\text { County Jurisdiction: Total Number of Projects, Approved Projects, Mitigated Negative } \\
\text { Declarations, and Construction Starts }\end{array}$} \\
\hline & Total Projects & $\begin{array}{c}\text { Approved } \\
\text { Projects }\end{array}$ & $\begin{array}{c}\text { Mitigated Negative } \\
\text { Declarations }\end{array}$ & $\begin{array}{c}\text { Construction } \\
\text { Starts }\end{array}$ \\
\hline Alameda & 1 & 0 & 0 & 0 \\
\hline Fresno & 7 & 1 & 4 & 0 \\
\hline Imperial & 3 & 3 & 0 & 2 \\
\hline Imperial Valley & 8 & 5 & 0 & 1 \\
\hline Kern & 14 & 6 & 0 & 1 \\
\hline Kings & 4 & 3 & 3 & 1 \\
\hline Los Angeles & 5 & 3 & 1 & 3 \\
\hline Madera & 1 & 1 & 1 & 0 \\
\hline Merced & 1 & 1 & 0 & 0 \\
\hline Panoche Hills & 1 & 1 & 0 & 0 \\
\hline San Benito & 1 & 1 & 0 & 0 \\
\hline San Bernardino & 2 & 1 & 0 & 0 \\
\hline San Diego & 2 & 0 & 0 & 2 \\
\hline San Luis Obispo & 3 & 2 & 0 & 0 \\
\hline Stanislaus & 3 & 3 & 3 & 1 \\
\hline Tulare & 1 & 1 & 1 & 11 \\
\hline Grand Total & 56 & 32 & 13 & \\
\hline
\end{tabular}

Thirty-two of the fifty-six county jurisdiction projects have been approved and eleven projects have started construction. Kern and Imperial Valley Counties have the most approvals, which is likely a function of the number of projects in these jurisdictions. However, Imperial Valley and Kern only have one construction start each. Los Angeles County has the largest number of construction starts (3), which that equal the number of approvals in that county. See Table 4.15 for the project approval and construction start numbers.

A difference between the CEC projects and the county projects is the ability of counties to grant a negative declaration during the planning process to reduce the environmental and public review process. Thirteen county projects out of fifty-six were granted mitigated negative declarations. Ten of these projects are in three counties. Fresno County has the most mitigated negative declarations at four, while Kings County and Stanislaus County have three each. Despite the potential reduction in process time, the mitigated declarations have not necessarily 
translated into construction starts as these three counties have only a total of two construction starts. See Table 4.15 for project numbers and Figure 4.8 for a visual of these numbers.

The total proposed land area for county jurisdiction projects is 120,771 acres with a total developed site area of 105,383.5 acres. Kern, Kings, and San Bernardino counties have the largest proposed project land areas. While this was expected for Kern County due to its large number of proposed projects, San Bernardino County has only two projects and Kings County has only four proposed projects. The average total site size has a wide range from 459 acres in Madera County to 6,581 acres in Kings County. The average developed site acreage ranges from 390.5 acres in Tulare County to 6,564.5 acres in Kings County. See Table 4.16 for the site area data including total and averages for total proposed site area and proposed developed site area.

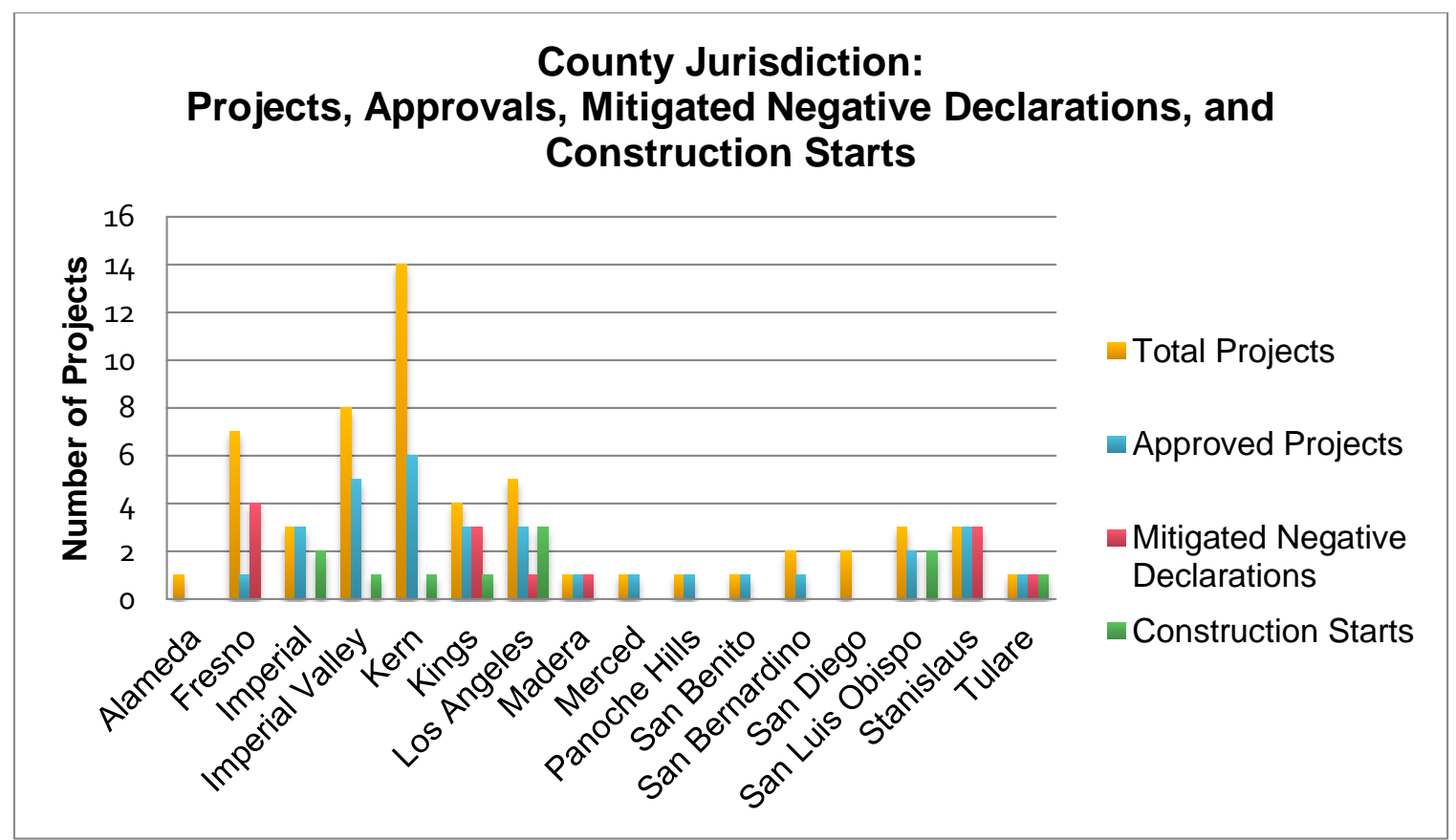

Figure 4.8 County Jurisdiction: Projects, Approvals, Mitigated Negative Declarations, and Construction 
Table 4.16 County Jurisdiction: Site Area

\begin{tabular}{|l|c|c|c|c|}
\hline \multicolumn{5}{|c|}{ County Jurisdiction: Site Area } \\
\hline & Total Site Area & $\begin{array}{c}\text { Total Developed } \\
\text { Area }\end{array}$ & $\begin{array}{c}\text { Average Total } \\
\text { Site Area }\end{array}$ & $\begin{array}{c}\text { Average } \\
\text { Developed Area }\end{array}$ \\
\hline Alameda & 2000 & 2000 & 2000 & 2000 \\
\hline Fresno & 6933 & 6933 & 990 & 990 \\
\hline Imperial & 3940 & 3865 & 1313 & 1288 \\
\hline Imperial Valley & 8049 & 8049 & 1006 & 1006 \\
\hline Kern & 32195 & 20836 & 24767 & 1603 \\
\hline Kings & 26325 & 26258 & 6581 & 6565 \\
\hline Los Angeles & 7456 & 7236 & 1491 & 1447 \\
\hline Madera & 459 & 459 & 459 & 459 \\
\hline Merced & 1012 & 1012 & 1012 & 1012 \\
\hline Panoche Hills & 4885 & 2437 & 4885 & 2437 \\
\hline San Benito & 4717 & 4717 & 4717 & 4717 \\
\hline San Bernardino & 9730 & 6113 & 4865 & 3057 \\
\hline San Diego & 1185 & 1185 & 592.5 & 593 \\
\hline San Luis Obispo & 6606 & 12105 & 4883 & 4183 \\
\hline Stanislaus & 4539 & 1788 & 1513 & 596 \\
\hline Tulare & 740 & 391 & 740 & 391 \\
\hline Grand Total & 120771 & 105384 & 2965 & 2361 \\
\hline
\end{tabular}

There is a wide range of process times across the counties from 79 days in Tulare County to 891 days in San Luis Obispo County. In the case of Tulare County's low number, this is likely due to the single project in this county receiving a mitigated negative declaration. As with the CEC project data, while there may seem to be a correlation between average process time and project approvals, statistically the correlation is only -0.068 . See Table 4.17 for process times by county and Figure 4.9 for a visual of process time compared to approvals by county.

\subsection{TRENDS OVER TIME}

In addition to looking at the project data based on jurisdiction, analysis was also conducted to determine any time trends in the gathered information. The most immediate finding is that there was a clear decline in project proposals between 2010 and 2011(see Table 4.18 and Figure 4.10). CSP projects have a slightly earlier drop off between 2009 and 2010 while PV projects drop off sharply after 2011. A potential reason for this trend is that the 1603 Treasury Program, which provided a source of financing for large solar projects, expired in 2011. 
Table 4.17 County Jurisdiction: Average Total Process Time (Days)

\begin{tabular}{|l|c|c|}
\hline \multicolumn{3}{|c|}{ County Jurisdiction: Average Total Process Time } \\
\hline & Days & Years \\
\hline Alameda & 0 & 0 \\
\hline Fresno & 441 & 1.21 \\
\hline Imperial & 313 & 0.86 \\
\hline Imperial Valley & 341 & 0.93 \\
\hline Kern & 606 & 1.66 \\
\hline Kings & 292 & 0.80 \\
\hline Los Angeles & 452 & 1.24 \\
\hline Madera & 210 & 0.58 \\
\hline Merced & 691 & 1.89 \\
\hline Panoche Hills & 225 & 0.62 \\
\hline San Benito & 245 & 0.67 \\
\hline San Bernardino & 1661 & 4.55 \\
\hline San Diego & 0 & 0 \\
\hline San Luis Obispo & 891 & 2.44 \\
\hline Stanislaus & 369 & 1.01 \\
\hline Tulare & 47 & 0.13 \\
\hline Grand Total & 480 & 1.32 \\
\hline
\end{tabular}

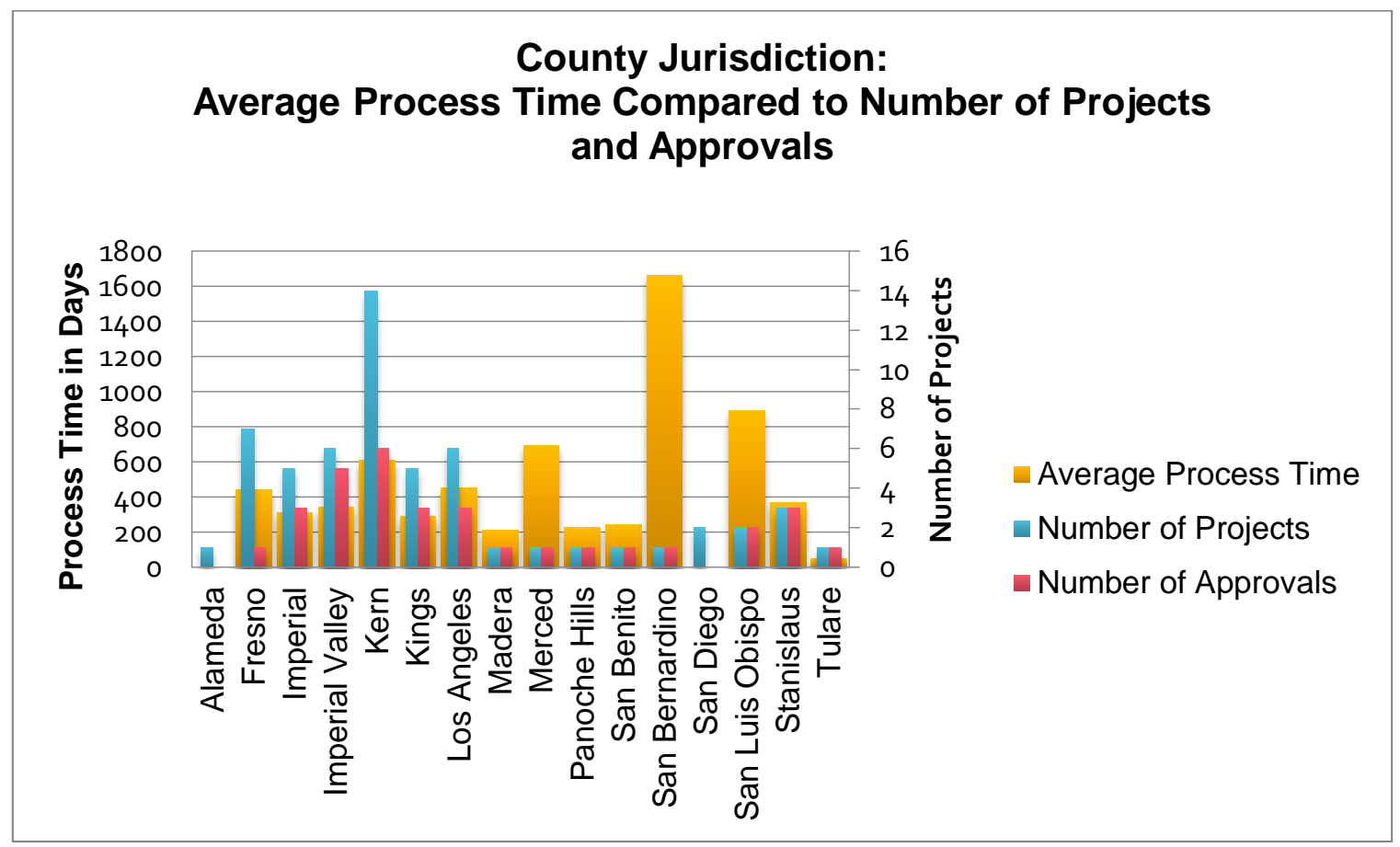

Figure 4.9 County Jurisdiction: Average Process Time Compared to Number of Projects and Approvals 
As opposed to the clear trend in project proposals, there was no clear pattern in the average project proposed generation capacity. Average capacity across all projects and PV decreases between 2008 and 2012, but there is a spike in CSP capacity in 2011. There is a large jump for total and PV in 2013 but this is primarily due to the lower project count for that year. There is no clearly apparent reason for this drop in average proposed capacity. There was no legislation or financial change during this time frame that stands out as a potential reason for the trend. Additional research would be needed to determine the cause. See Table 4.19 and Figure 4.11 for the data on average generation capacity over time.

The average total proposed site acreage had similar trends as the average generation capacity. Project acreage peaked in 2008 and then steadily declined until 2013 . There is a spike in CSP project size in 2011 but otherwise the trend is towards gradually smaller projects. As noted previously, there is no readily apparent cause for this shift. More research is needed in this area. See Table 4.20 and Figure 4.12 for the data pertaining to average site size compared to process start year.

From the perspective of when projects complete their public process as opposed to start the process, there is a slight increase in the number of approved projects between 2010 and 2012 followed by a decrease in 2013. There is a slight dip in approvals in 2012 due to the fact that there were no CEC approvals that year. A likely cause for the drop in 2013 is lag from the drop in project proposals in 2011 , as the public process averages over a year at minimum. See Table 4.21 and Figure 4.13 for additional data on approved projects by process end year. 
Table 4.18 Proposed Projects by Process Start Year

\begin{tabular}{|l|c|c|c|}
\hline \multicolumn{4}{|c|}{ Proposed Projects by Process Start Year } \\
\hline & CSP & PV & Grand Total \\
\hline Before 2006 & 2 & 0 & 2 \\
\hline 2007 & 3 & 0 & 3 \\
\hline 2008 & 3 & 1 & 4 \\
\hline 2009 & 7 & 3 & 10 \\
\hline 2010 & 0 & 18 & 18 \\
\hline 2011 & 3 & 22 & 25 \\
\hline 2012 & 0 & 7 & 7 \\
\hline 2013 & 0 & 5 & 5 \\
\hline (blank) & 1 & 5 & 60 \\
\hline Grand Total & 19 & 61 & 6 \\
\hline
\end{tabular}

${ }^{*}$ CSP: Concentrating Solar Power

*PV: Photovoltaic

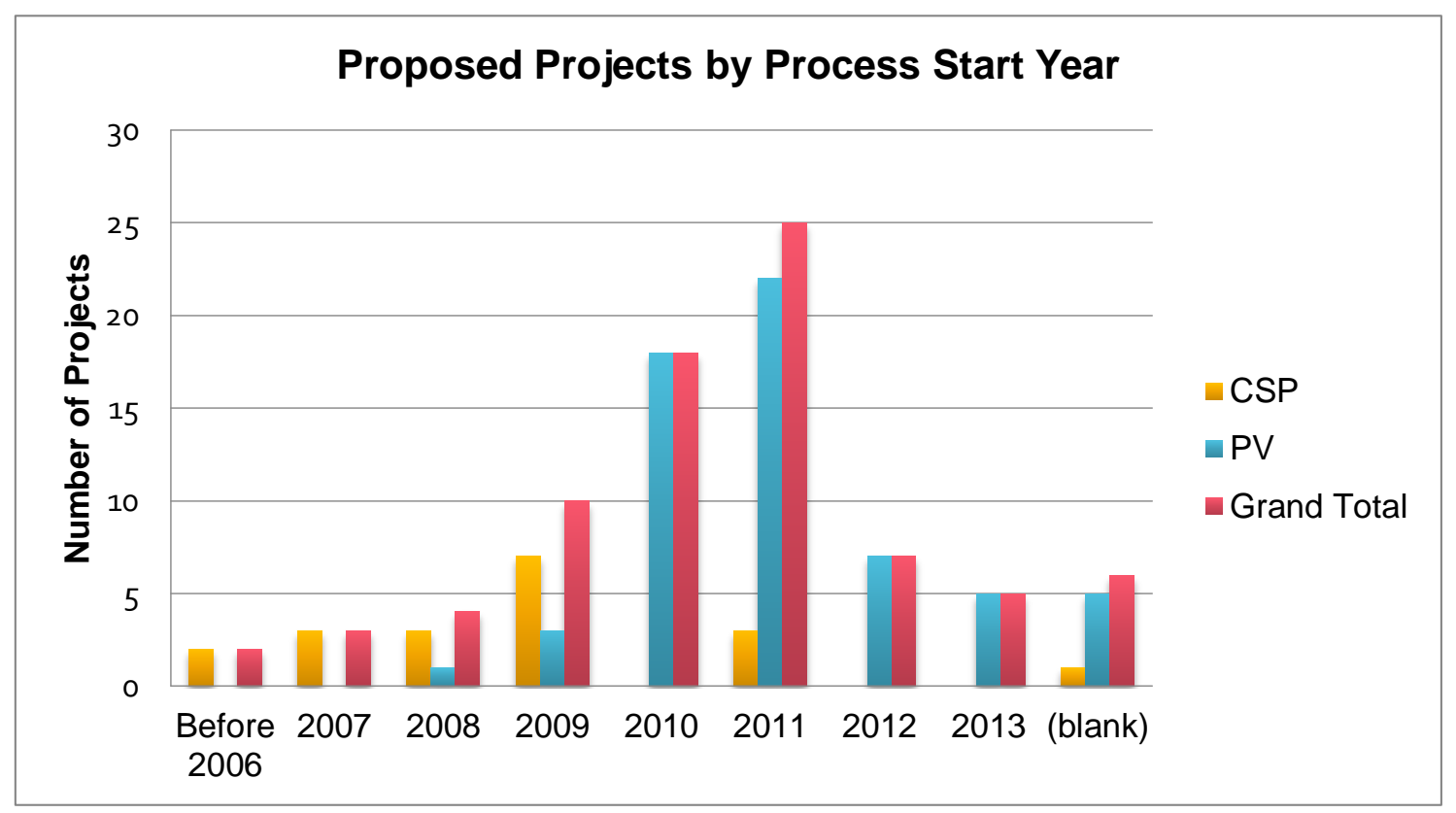

${ }^{*}$ CSP: Concentrating Solar Power

*PV: Photovoltaic

Figure 4.10 Proposed Projects by Process Start Year 
Table 4.19 Average Proposed Generation Capacity by Process Start Year

\begin{tabular}{|l|c|c|c|}
\hline \multicolumn{4}{|c|}{ Average Proposed Generation Capacity by Process Start Year } \\
\hline & CSP & PV & Grand Total \\
\hline Before 2006 & 200 & 0 & 200 \\
\hline 2007 & 516 & 0 & 516 \\
\hline 2008 & 526 & 550 & 532 \\
\hline 2009 & 329 & 171 & 282 \\
\hline 2010 & 0 & 240 & 240 \\
\hline 2011 & 600 & 155 & 208 \\
\hline 2012 & 0 & 123 & 123 \\
\hline 2013 & 0 & 880 & 880 \\
\hline (blank) & 500 & 226 & 272 \\
\hline Grand Total & 427 & 249 & 291 \\
\hline
\end{tabular}

${ }^{*}$ CSP: Concentrating Solar Power

*PV: Photovoltaic

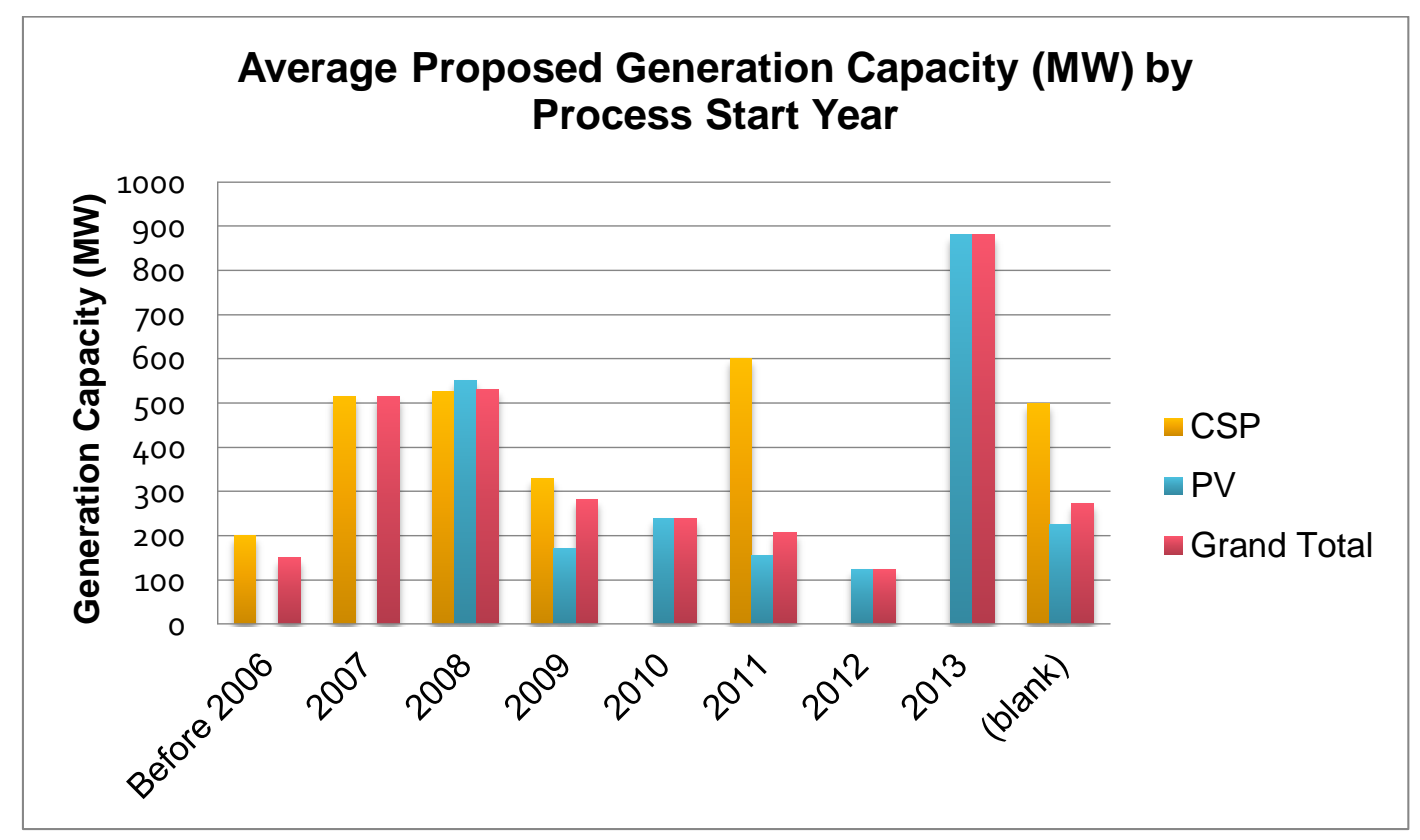

${ }^{*}$ CSP: Concentrating Solar Power

*PV: Photovoltaic

Figure 4.11 Average Proposed Generation Capacity (MW) by Process Start Year 
Table 4.20 Average Proposed Total Site Acreage by Process Start Year

\begin{tabular}{|l|c|c|c|}
\hline \multicolumn{4}{|c|}{ Average Proposed Total Site Acreage by Process Start Year } \\
\hline & CSP & PV & Grand Total \\
\hline Before 2006 & 700 & 0 & 1000 \\
\hline 2007 & 3057 & 0 & 3057 \\
\hline 2008 & 5534 & 4000 & 5151 \\
\hline 2009 & 5075 & 1722 & 4069 \\
\hline 2010 & 0 & 1721 & 1721 \\
\hline 2011 & 2969 & 1224 & 1434 \\
\hline 2012 & 0 & 1127 & 1127 \\
\hline 2013 & 0 & 10771 & 10771 \\
\hline (blank) & 0 & 1505 & 1505 \\
\hline Grand Total & 3978 & 2093 & 2523 \\
\hline
\end{tabular}

${ }^{*}$ CSP: Concentrating Solar Power

*PV: Photovoltaic

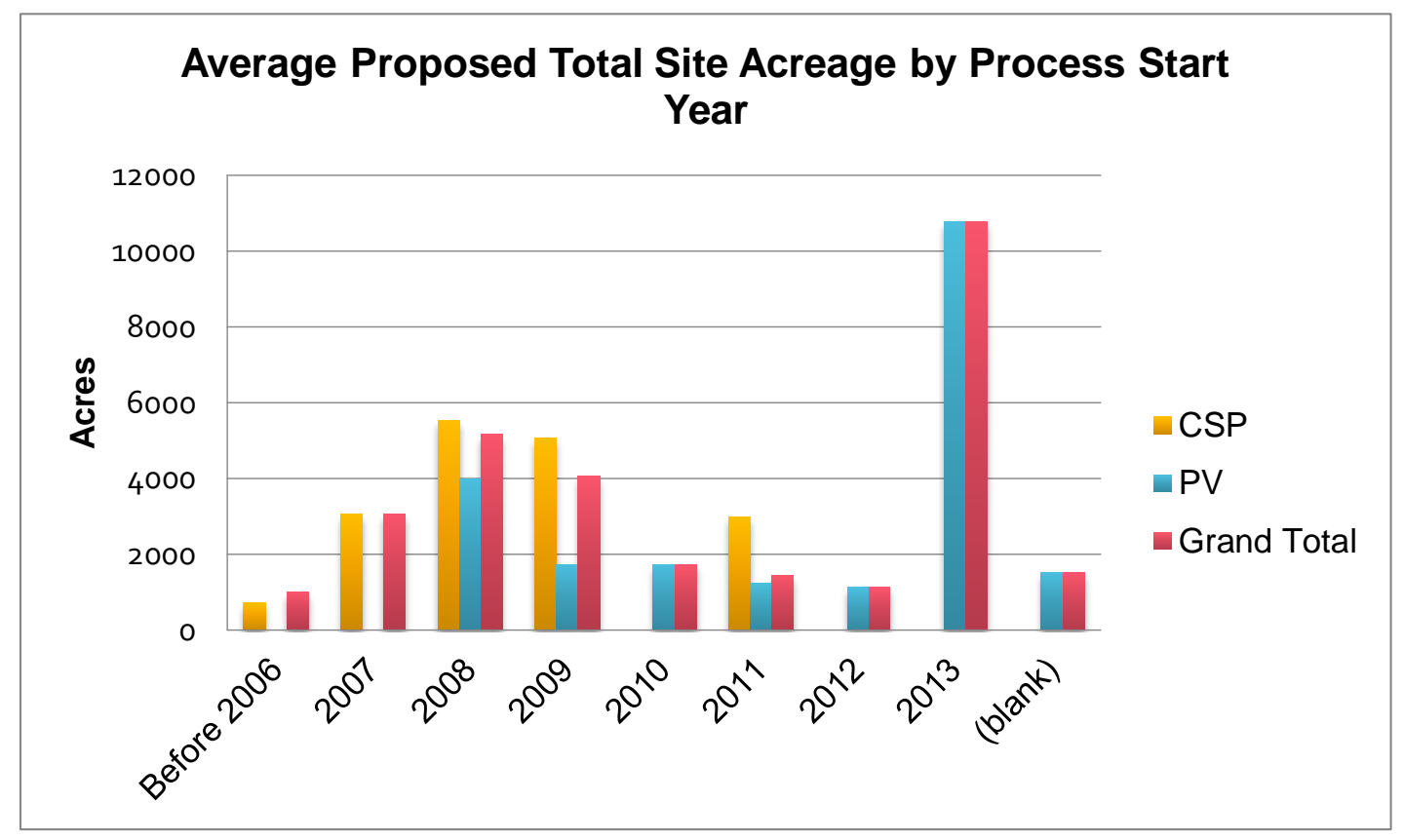

${ }^{*}$ CSP: Concentrating Solar Power

*PV: Photovoltaic

Figure 4.12 Average Proposed Total Site Acreage by Process Start Year 
Table 4.21 Total Approved Projects by Process End Year

\begin{tabular}{|l|c|c|c|}
\hline \multicolumn{4}{|c|}{ Total Approved Projects by Process End Year } \\
\hline & CSP & PV & Total \\
\hline Before 2009 & 1 & 0 & 2 \\
\hline 2009 & 0 & 0 & 0 \\
\hline 2010 & 7 & 6 & 13 \\
\hline 2011 & 0 & 10 & 10 \\
\hline 2012 & 2 & 14 & 16 \\
\hline 2013 & 1 & 5 & 6 \\
\hline 2014 & 0 & 1 & 1 \\
\hline Grand Total & 11 & 36 & 47 \\
\hline
\end{tabular}

${ }^{*}$ CSP: Concentrating Solar Power

${ }^{*} \mathrm{PV}$ : Photovoltaic

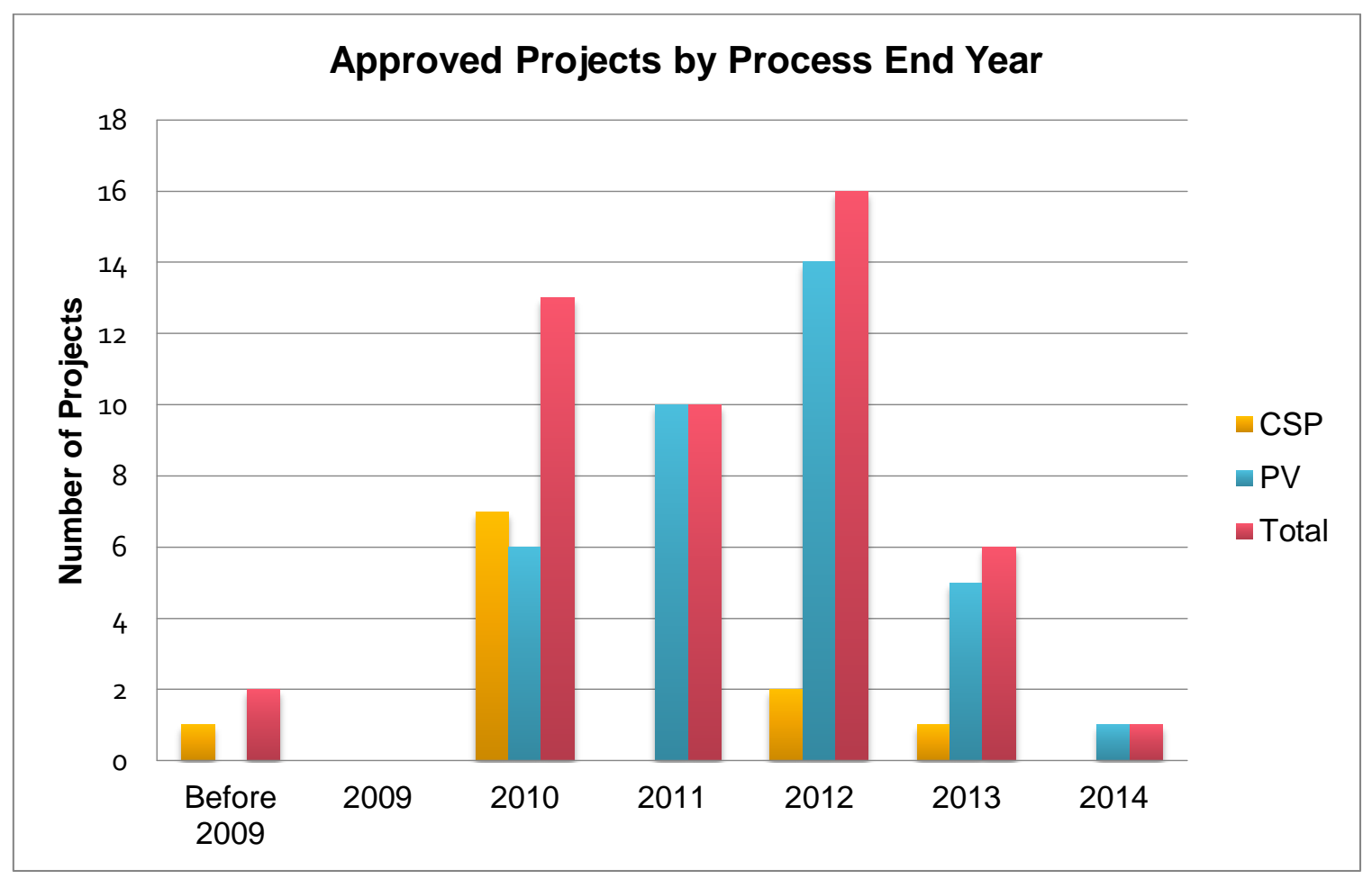

*CSP: Concentrating Solar Power

*PV: Photovoltaic

Figure 4.13 Approved Projects by Process End Year 


\section{CHAPTER 5: CONCLUSIONS}

Utility-scale solar projects will likely remain an important facet of California's energy development as the state moves towards meeting the Renewable Portfolio Standard (RPS). Solar projects differ from traditional energy developments due to their widespread general support, potential local opposition, and site requirements. Understanding the factors that improve project acceptance, approval, and complete development will be vitally important as California moves towards increasing renewable energy generation.

The purpose of this project was to develop a database and provide initial analysis on utility-scale solar projects, those with a proposed generation capacity of $50 \mathrm{MW}$ or greater, in California. The database was developed through public document searches with the final database including eighty projects. Analysis focused around understanding the current makeup of large-scale solar projects, an analysis of the different jurisdiction's projects, and a quick look at trends over time.

\subsection{GENERAL FINDINGS}

The majority of projects are proposed use photovoltaic (PV) technology not concentrating solar power (CSP). Twenty-four percent of the total projects were proposed with CSP technology while seventy-six percent of projects used PV as the original technology (see Table. 5.1). There are a very limited number of projects that reached construction start, twenty-three percent of all projects, while fewer still (13\%) became operational. Due to the preliminary nature of this project, there is no clear reason for the low number of fully operational projects. Additional research is needed in this area.

Table 5.1 Percent Projects by Initial Technology

\begin{tabular}{|l|c|c|}
\hline \multicolumn{3}{|c|}{ Percent Projects by Initial Technology } \\
\hline & Number of Projects & Percent of Total Projects \\
\hline Concentrating Solar Thermal & 19 & 24 \\
\hline Photovoltaic & 61 & 76 \\
\hline
\end{tabular}


Projects were concentrated in six California counties out of the eighteen represented in the database: Kern, San Bernardino, Riverside, Imperial Valley, Fresno, and Imperial. These counties represent seventy percent of all proposed projects with fifty-six total projects, sixty-six percent of all approvals, and sixty-one percent of all construction starts. This cluster of development may be caused by a variety of factors including a positive political atmosphere for development, strong solar radiation, or availability of land. It also may be problematic for these jurisdictions moving forward if the local public begins to feel that they are receiving an unfair burden for the benefit of other cities (Carlisle et al., 2015; Hall et al., 2013).

\subsection{COMPARING THE CALIFORNIA ENERGY COMMISSION AND COUNTY JURISDICTIONS}

Due to the large proportion of proposed PV projects, the CEC has a minority of all projects in its jurisdiction. However, neither process is more effective in project approvals or construction. In fact, for each process fifty-six percent of projects received approval and nineteen percent started construction (see Table 5.2). Despite the CEC having a streamlined process with a twelve month timeline, the average process time for the CEC is twenty-two months with no technology switches which is greater than the twelve to eighteen month timeframe proposed for

traditional power plants (CEC, 2006). This contrasts with the average county process time of 13 months with no switch from CSP to PV that is still longer than the CEC's goal of twelve months but still nine months faster than the CEC average time. Despite this difference, process length was not found to be a significant factor in project approval for either the CEC or the counties. More research is needed to determine both the factors for project approval as well as what is causing the CEC process to be dramatically longer than its designed timeline. 
Table 5.2 Comparison of Percent Projects Approved and Constructed by Jurisdiction

\begin{tabular}{|l|c|c|}
\hline \multicolumn{3}{|c|}{ Comparison of Percent Projects Approved and Constructed by Jurisdiction } \\
\hline & $\begin{array}{c}\text { Percent of Projects } \\
\text { Approved }\end{array}$ & $\begin{array}{c}\text { Percent of Projects } \\
\text { Constructed }\end{array}$ \\
\hline County & 56 & 19 \\
\hline California Energy Commission & 56 & 19 \\
\hline Grand Total of All Jurisdictions & 59 & 23 \\
\hline
\end{tabular}

\subsection{TRENDS OVER TIME}

The most important finding in the analysis of trends over time was the dramatic decrease in project proposals in 2011, with a slightly earlier decrease in CEC proposals in 2009 . This trend was further supported by a decrease in project approvals in 2012, which would account for the average process of approximately eighteen months. An initial hypothesis on the cause of this decrease is the expiration of the Federal 1603 Treasury Program, which provided a source of financing for large solar projects. However, there may be other causes for this shift in project proposals including other financial or political factors. Additional research will be needed to determine the specific causes of this change.

\subsection{FURTHER RESEARCH}

The findings of this research are preliminary in scope and require additional fact finding and analysis to create a clear picture of the utility-scale solar environment in California. In particular, determination of the factors of project success for approval, construction, and operation will be vital as increasing numbers of projects are proposed to meet the RPS standard. While most research has focused on the public acceptance of projects, the financial and political aspects of the planning process should receive further attention.

The dual approval process that currently is used in California for utility-scale solar projects is also an area for further study. While the early findings indicated that there is no significant difference in project success under either system, further research should be conducted to verify this. Investigation should also focus on the need for these two separate approval paths and whether it may be more useful to have one unified planning path. 
Additionally, research into these two processes may yield information on methods to improve the effectiveness and efficiency of the review process.

A final area of concern for further analysis is the effect of site characteristics on project approval rates. The areas where utility-scale solar projects are proposed are often rural, undeveloped or underdeveloped, contain endangered or threatened species, and have little to no access to water. Due to time constraints, these factors were not fully considered in the database. However, they remain a cause for concern in the planning, construction, and operation of these facilities. Specifically, species including the desert tortoise, golden eagle, and several plant varieties have been impacted by current developments and will also be by future developments. Whether site-specific environmental concerns, such as adverse effects on local wildlife and changes to local water resources, affect project success are areas for further study. 


\section{BIBLIOGRAPHY}

American Planning Association. (2011). Policy Guide on Planning and Climate Change. In A. P. Association (Ed.).

Anderson, C., Schirmer, J., \& Abjorensen, N. (2011). Exploring CCS community acceptance and public participation from a human and social capital perspective. Mitigation and Adaptation Strategies for Global Change, 17(6), 687-706. doi: 10.1007/s11027-011-9312-z

Anonymous. (2007). Solar Power Gets Extra Heat in California. In Business, 29(1), 5.

Azoumah, Y., Rambe, E. W., Tapsoba, G., \& Thiam, S. (2010). Siting guidelines for concentrating solar power plants in the Sahel: Case study of Burkina Faso. Solar Energy, 84, 1182-1200.

Ball, R. H., Salter, R. G., Dole, S., Frederich, B., Hammer, M., Mooz, W. E., . . . Richards, G. (1972). California's Electricity Quandry: Planning for Power Plant Siting. (R-1115-RF/CSA). Santa Monica, CA: Rand.

Baratta, A. (2011). Renewable Energy: Status and Prospects - Status of Electricity Generation from Renewable Energy. 38, 157-189. doi: 10.1007/978-90-481-3153-2_5

Barbour, E., \& Teitz, M. B. (2005). CEQA reform: Issues and options: Public Policy Institute of California San Francisco, CA.

Bell, D., Gray, T., \& Haggett, C. (2005). The 'Social Gap’ in Wind Farm Siting Decisions: Explanations and Policy Responses. Environmental Politics, 14(4), 460-477. doi: 10.1080/09644010500175833 
Besley, J. C. (2010). Public Engagement and the Impact of Fairness Perceptions on Decision Favorability and Acceptance. Science Communication, 32(2), 256-280. doi: 10.1177/1075547009358624

Burningham, K., Barnett, J., \& Thrush, D. (2006). The limitations of th NIMBY concept for understanding public engagement with renewable energy technologies: A literature review. Manchester: University of Manchester School of Environment and Development.

Burningham, K., Barnett, J., \& Thrush, D. (2006). The limitations of the NIMBY concept for understanding public engagement with renewable energy technologies: a literature review. Retrieved from:

http://www.sed.manchester.ac.uk/research/beyond nimbyism

California Public Utilities Commission. (2009). 33\% Renewables Portfolio Standard: Implementation Analysis Preliminary Results. Sacramento, California: California Public Utilities Commission.

Carley, S. (2011). The Era of State Energy Policy Innovation: A Review of Policy Instruments. Review of Policy Research, 28(3), 265-294.

Carlisle, J. E., Kane, S. L., Solan, D., Bowman, M., \& Joe, J. C. (2015). Public attitudes regarding large-scale solar energy development in the U.S. Renewable and Sustainable Energy Reviews, 48(0), 835-847. doi: http://dx.doi.org/10.1016/j.rser.2015.04.047

CEC. (1983). Securing California's Energy Future: 1983 Biennial Report to the Governor and the Legislature. Sacramento. 
CEC. (1992). The 1992-1993 California Energy Plan: The Biennial Energy Report of the California Energy Commission. Sacramento.

CEC. (2000). Energy Facility Licensing Process: Developers Guide of Practices and Procedures. (P700-00-007). Sacramento.

CEC. (2003). Energy Action Plan. Sacramento: Retrieved from http://www.energy.ca.gov/energy action plan/2003-0508 ACTION PLAN.PDF.

CEC. (2006). Public Participation in the Siting Process: Practice and Procedure Guide. (CEC-700-2006-002). Sacramento.

CEC (Producer). (2007, May 20, 2015). Memorandum of Understanding Between the U.S. Department of the Interior, Bureau of Land Management California Desert District, and the California Energy Commission Staff: Concerning Joint Environmental Review for Solar Thermal Plant Projects. Retrieved from http://www.energy.ca.gov/siting/solar/BLM CEC MOU.PDF CEC. (2010). 2010 Integrated Energy Policy Report Update. (CEC-100-2010001-CMF). Sacremento, CA.

CEC. (2011a). 2010 Integrated Energy Policy Report Update. (CED-100-2010001-CMF). Sacramento, California: California Energy Commission. CEC. (2011b). 2011 Integrated Energy Policy Report. (CEC-100-2011-001CMF). Sacramento, California: California Energy Commission.

CEC. (2011c). Renewable Power in California: Status and Issues. (CEC- 1502011- 002- LCF- REV1). Sacramento: Retrieved from 
http://www.energy.ca.gov/2011publications/CEC-150-2011-002/CEC-1502011-002-LCF-REV1.pdf.

CEC. (2012a). 2012 Integrated Energy Policy Report Update. (CEC- 100- 2012001- LCD). Sacramento, California: California Energy Commission.

CEC (Producer). (2012b, May 30, 2015). Solar Thermal Projects Under Review.

Retrieved from http://www.energy.ca.gov/siting/solar/

CEC. (2013). Renewable Energy Action Team-Generation Tracking for

Renewable Projects. Retrieved from:

http://www.energy.ca.gov/33by2020/documents/renewable projects/REAT

Generation Tracking Projects Report.pdf

CEC (Producer). (2014, 3/10/2015). Solar Power Plant Licensing Projects.

Retrieved from

http://www.energy.ca.gov/maps/documents/Solar Power Plant Licensing Projects.pdf

Center for Climate and Energy Solutions. (2011). Climate Techbook: Electricity

Overview. Retrieved 5-10-2012, 2012, from http://www.c2es.org/technology/overview/electricity

Chiabrando, R., Fabrizio, E., \& Garnero, G. (2009). The territorial and landscape impacts of photovoltaic systems: Definition of impacts and assessment of the glare risk. Renewable and Sustainable Energy Reviews, 13(9), 24412451. doi: 10.1016/j.rser.2009.06.008 
County of San Bernardino Land Use Services and Planning Division. (2015).

Renewable Energy Projects as of May 7, 2015. Retrieved from:

http://www.sbcounty.gov/uploads/lus/renewable/SolarProjectList.pdf

County of San Diego Department of Planning and Land Use Regulatory Planning

Division (Producer). (2003, May 20, 2015). Simplified EIR Process

Flowchart. Retrieved from

http://www.sandiegocounty.gov/content/dam/sdc/pds/docs/EIR-

flowchart.jpg

Cowell, R., Bristow, G., \& Munday, M. (2011). Acceptance, acceptability and environmental justice: the role of community benefits in wind energy development. Journal of Environmental Planning and Management, 54(4), 539-557. doi: 10.1080/09640568.2010.521047

CPUC. (2015). California Renewables Portfolio Standard (RPS). Retrieved from: http://www.cpuc.ca.gov/PUC/energy/Renewables/

Del Chiaro, B., \& Gibson, R. (2010). Government's Role in Creating a Vibrant Solar Power Market in California. Golden Gate University Law Review, 36(3), 347-391.

Desert Renewable Energy Conservation Plan Environmental Impact Report:

Cumulative Impacts Analysis. (2014). Retrieved from:

http://www.drecp.org/draftdrecp/files/e Volume IV/IV.25 Cumulative Imp acts Analysis.pdf

Desideri, U., Zepparelli, F., Morettini, V., \& Garroni, E. (2013). Comparative analysis of concentrating solar power and photovoltaic technologies: 
Technical and environmental evaluations. Applied Energy, 102(0), 765784. doi: http://dx.doi.org/10.1016/j.apenergy.2012.08.033

Devine-Wright, P. (2007). Reconsidering public attitudes and public acceptance of renewable energy technologies: a critical review. Manchester: School of Environment and Development, University of Manchester. Available at: http://www. sed. manchester. ac. uk/research/beyond_nimbyism.

Devine-Wright, P. (2011). Public engagement with large-scale renewable energy technologies: breaking the cycle of NIMBYism. Wiley Interdisciplinary Reviews: Climate Change, 2(1), 19-26. doi: 10.1002/wcc.89

Dinçer, F. (2011). The analysis on photovoltaic electricity generation status, potential and policies of the leading countries in solar energy. Renewable and Sustainable Energy Reviews, 15(1), 713-720. doi:

10.1016/j.rser.2010.09.026

Doris, E. B., Busche, S., Hockett, S., \& Loring, J. M. (2009). The role of state policy in renewable energy development. Paper presented at the ASME 2009 3rd International Conference on Energy Sustainability collocated with the Heat Transfer and InterPACK09 Conferences.

Dütschke, E. (2011). What drives local public acceptance-comparing two cases from Germany. Energy Procedia, 4, 6234-6240.

EIA (Producer). (2014, May 20, 2015). U.S. Net Electricity Generation by Energy Source (2013). Monthly Energy Review. Retrieved from http://www.eia.gov/totalenergy/data/monthly/\#electricity. 
Eltham, D. C., Harrison, G. P., \& Allen, S. J. (2008). Change in public attitudes towards a Cornish wind farm: Implications for planning. Energy Policy, 36(1), 23-33. doi: 10.1016/j.enpol.2007.09.010

ESA. (2012). Solar Gen 2 Solar Array Project Environmental Impact Report: Cumulative Impacts. Retrieved from: ftp://ftp.co.imperial.ca.us/icpds/eir/solar-gen-2-solar-array/18cumulativeimpacts.pdf

Felder, F. A., \& Haut, R. (2008). Balancing alternatives and avoiding false dichotomies to make informed U.S. electricity policy. Policy Sciences, 41(2), 165-180. doi: 10.1007/s11077-008-9061-3

Fleishman, L. A., De Bruin, W. B., \& Morgan, M. G. (2010). Informed public preferences for electricity portfolios with CCS and other low-carbon technologies. Risk Anal, 30(9), 1399-1410. doi: 10.1111/j.1539$6924.2010 .01436 . x$

Fthenakis, V., Mason, J. E., \& Zweibel, K. (2009). The technical, geographical, and economic feasibility for solar energy to supply the energy needs of the US. Energy Policy, 37(2), 387-399. doi: 10.1016/j.enpol.2008.08.011

Gatrell, J. D., \& Jensen, R. R. (2009). Spatial Analysis, Policy Planning, and Alternative Energy Production (Vol. 1).

Groom, N., \& Chan, E. (2011). California Tosses Out Solar Power Plant Lawsuit. Green Buisness. Retrieved from

Gross, C. (2007). Community perspectives of wind energy in Australia: The application of a justice and community fairness framework to increase 
social acceptance. Energy Policy, 35(5), 2727-2736. doi:

10.1016/j.enpol.2006.12.013

Grueneich, D. M., Gold, D., Imwalle, M., \& Esformes, P. (Producer). (2011, 3/10/2015). 2011 California Renewable Energy Legislation: Watershed Year for Streamlining, Siting and Permitting. [Online Article] Retrieved from http://media.mofo.com/files/Uploads/Images/110913-2011-California$\underline{\text { Renewable-Energy-Legislation-Watershed-Year.pdf }}$

Hall, N., Ashworth, P., \& Devine-Wright, P. (2013). Societal acceptance of wind farms: Analysis of four common themes across Australian case studies. Energy Policy, 58(0), 200-208. doi: http://dx.doi.org/10.1016/j.enpol.2013.03.009

Heras-Saizarbitoria, I., Cilleruelo, E., \& Zamanillo, I. (2011). Public acceptance of renewables and the media: an analysis of the Spanish PV solar experience. Renewable and Sustainable Energy Reviews, 15(9), 46854696. doi: 10.1016/j.rser.2011.07.083

Hosenuzzaman, M., NRahim, N. A., Selvaraj, J., Hasanuzzaman, M., Malek, A. B. M. A., \& Nahar, A. (2015). Global prospects, progress, policies, and environmental impact of solar photovoltaic power generation. Renewable and Sustainable Energy Reviews, 41, 284-297.

Hughes, L. (2009). The four 'R's of energy security. Energy Policy, 37(6), 24592461. doi: http://dx.doi.org/10.1016/j.enpol.2009.02.038 
Hunold, C., \& Leitner, S. (2011). 'Hasta la vista, baby!' The Solar Grand Plan, environmentalism, and social constructions of the Mojave Desert. Environmental Politics, 20(5), 687-704.

Jackson, T., \& Oliver, M. (2000). The viability of solar photovoltaics. Energy Policy, 28, 983-988.

Jacobson, M. Z., \& Delucchi, M. A. (2011). Providing all global energy with wind, water, and solar power, Part I: Technologies, energy resources, quantities and areas of infrastructure, and materials. Energy Policy, 39(3), 11541169. doi: 10.1016/j.enpol.2010.11.040

Jobert, A., Laborgne, P., \& Mimler, S. (2007). Local acceptance of wind energy: Factors of success identified in French and German case studies. Energy Policy, 35(5), 2751-2760. doi: 10.1016/j.enpol.2006.12.005

Kern County Planning Department (Producer). (2013, May 30, 2015). Kern County Solar Projects. Retrieved from https://www.co.kern.ca.us/planning/pdfs/renewable/solar projects.pdf

Kontogianni, A., Tourkolias, C., Skourtos, M., \& Damigos, D. (2014). Planning globally, protesting locally: Patterns in community perceptions towards the installation of wind farms. Renewable Energy, 66(0), 170-177. doi: http://dx.doi.org/10.1016/j.renene.2013.11.074 Maloney, P. (2008, September 24, 2008). Amid Protests, Solar Companies Plan Desert Projects. New York Times. Maloney, P. (2008, 9/24/2008). Amid Protests, Solar Companies Plan Desert Projects. New York Times, p. 1. 
Martin, N., \& Rice, J. (2015). Improving Australia's renewable energy project policy and planning: A multiple stakeholder analysis. Energy Policy, 84(0), 128-141. doi: http://dx.doi.org/10.1016/j.enpol.2015.04.034

Mills, D. (2004). Advances in solar thermal electricity technology. Solar Energy, 76(1-3), 19-31. doi: 10.1016/s0038-092x(03)00102-6

Mingasson, G. (Producer). (2015, May 20, 2015). Ivanpah: World's Largest Concentrating Solar Power Plant. Retrieved from http://energy.gov/photos/ivanpah-worlds-largest-concentrating-solarpower-plant

Nadaï, A., \& van der Horst, D. (2010). Wind power planning, landscapes and publics. Land Use Policy, 27(2), 181-184. doi:

10.1016/j.landusepol.2009.09.009

NREL (Producer). (2010a, May 20, 2015). Concentrating Solar Resource of the United States. Retrieved from http://www.nrel.gov/gis/images/eere csp/national concentrating solar 20 12-01.jpg

NREL (Producer). (2010b, May 20, 2015). Photovoltaic Solar Resource of the United States. Retrieved from http://www.nrel.gov/gis/images/eere pv/national photovoltaic 2012-01.jpg Olshansky, R. B. (1996). The California Environmental Quality Act and local planning. American Planning Association. Journal of the American Planning Association, 62(3), 313. 
Painuly, J. P. (2001). Barriers to renewable energy penetration; a framework for analysis. Renewable Energy, 24(1), 73-89. doi: http://dx.doi.org/10.1016/S0960-1481(00)00186-5

Papetti, R., Dole, S. H., \& Hammer, M. J. (1973). Air pollution and power plant siting in California: Rand.

Pasqualetti, M. J. (2011). The Next Generation of Energy Landscapes. 461-482. doi: 10.1007/978-90-481-9920-4_27

Phadke, R. (2011). Resisting and Reconciling Big Wind: Middle Landscape Politics in the New American West. Antipode, 43(3), 754-776. doi: $10.1111 / \mathrm{j} .1467-8330.2011 .00881 . x$

Pimentel, D., Merz, M., Glickstein, M., Zimmerman, M., Allen, R., Becker, K., E., J., . . Seidel, T. (2002). Renewable Energy: Current and Potential Issues. Bioscience, 52(12), 1111-1120.

Resch, G., Held, A., Faber, T., Panzer, C., Toro, F., \& Haas, R. (2008). Potentials and prospects for renewable energies at global scale. Energy Policy, 36(11), 4048-4056. doi: 10.1016/j.enpol.2008.06.029

Riverside County Planning Department (Producer). (2015, May 20, 2015).

Entitlement Process II Flowchart. Retrieved from http://planning.rctlma.org/Portals/0/devproc/flowcharts/process two.pdf

Romero, M., \& González-Aguilar, J. (2014). Solar thermal CSP technology. Wiley Interdisciplinary Reviews: Energy and Environment, 3(1), 42-59. doi: 10.1002/wene.79 
Roth, S. (2014). Lawsuit Over Desert Solar Plants' Bird Deaths. The Desert Sun. Retrieved from http://www.desertsun.com/story/news/environment/2014/08/22/solar-plantagencies-lawsuit/14426871/

Sahagun, L. (2014). Native Americans Challenge Construction of Mojave Desert Solar Plan. LA Times. Retrieved from http://www.latimes.com/science/sciencenow/la-sci-sn-native-americanssolar-20141212-story.html

Sayigh, A. (2009). Worldwide progress in renewable energy. Renewable Energy. doi: 10.1016/j.renene.2008.12.025

SEIA. (2015). Major Solar Projects in the United States: Operating, Under Construction, or Under Development. from Solar Energy Industries Association http://www.seia.org/sites/default/files/resources/PUBLIC\%20Major\%20Pro jects\%20List\%202015-2-23.pdf

Sen, Z. (2008). Energy and Climate Change Solar Energy Fundamentals and Modeling Techniques: Springer.

Sherwood, L. (2014). U.S. Solar Market Trends 2013: Interstate Renewable Energy Council.

Simon, C. A. (2009). Cultural Constraints on Wind and Solar Energy in the U.S. Context. Comparative Technology Transfer and Society, 7(3), 251-269. Sissine, F. (2007). Energy Independence and Security Act of 2007: A Summary of Major Provisions. (ADA475228). Washington, D.c.: Congressional 
Research Service Retrieved from http://www.dtic.mil/cgibin/GetTRDoc? Location=U2\&doc=GetTRDoc.. pdf \&AD=ADA475228.

Solangi, K. H., Islam, M. R., Saidur, R., Rahim, N. A., \& Fayaz, H. (2011). A review on global solar energy policy. Renewable and Sustainable Energy Reviews, 15(4), 2149-2163. doi: 10.1016/j.rser.2011.01.007

SOLAREIS (Producer). (2015, May 20, 2015). Solar Arrays. Retrieved from http://solareis.anl.gov/guide/solar/pv/index.cfm

Stillwell, B. A. (2011). Solar Energy: The Key to Unlocking California's Power Gridlock and Reducing Greenhouse Emissions. (Doctor of Philosophy), Capella University.

Swofford, J., \& Slattery, M. (2010). Public attitudes of wind energy in Texas: Local communities in close proximity to wind farms and their effect on decision-making. Energy Policy, 38(5), 2508-2519. doi:

10.1016/j.enpol.2009.12.046

Taylor, M. (2008). Beyond technology-push and demand-pull: Lessons from California's solar policy. Energy Economics, 30(6), 2829-2854. doi: 10.1016/j.eneco.2008.06.004

The Vote Solar Initiative (Producer). (2009, May 1, 2014). The Sun Rises On Nevada: Economic and Environmental Impacts of Developing 2,000 MW of Large-Scale Solar Power Plant.

The Vote Solar Initiative. (2012, Feb 9, 2012). Southern California Desert Communities Overwhelmingly Support Solar Development According to New Poll. Business Wire. 
Timilsina, G. R., Kurdgelashvili, L., \& Narbel, P. A. (2012). Solar energy: Markets, economics and policies. Renewable and Sustainable Energy Reviews, 16(1), 449-465. doi: 10.1016/j.rser.2011.08.009

Tsoutsos, T., Frantzeskaki, N., \& Gekas, V. (2005). Environmental impacts from the solar energy technologies. Energy Policy, 33(3), 289-296. doi: $10.1016 / \mathrm{s} 0301-4215(03) 00241-6$

Turney, D., \& Fthenakis, V. (2011). Environmental impacts from the installation and operation of large-scale solar power plants. Renewable and Sustainable Energy Reviews, 15(6), 3261-3270. doi: 10.1016/j.rser.2011.04.023

van der Horst, D. (2007). NIMBY or not? Exploring the relevance of location and the politics of voiced opinions in renewable energy siting controversies. Energy Policy, 35(5), 2705-2714. doi: 10.1016/j.enpol.2006.12.012 Varner, S. S. (1991). California Environmental Quality Act (CEQA) after Two Decades: Relevant Problems and Ideas for Necessary Reform, The. Pepp. L. Rev., 19, 1447.

Webler, T., \& Tuler, S. (2000). Fairness and Competence in Citizen Participation: Theoretical Reflections from a Case Study. Administration \& Society, 32(5), 566-595. doi: 10.1177/00953990022019588

Weil, B. S. (2009). Renewable energy in California: Changing policies, politics and values, 1975--2005. 
Wiser, R., Barbose, G., \& Holt, E. (2011). Supporting solar power in renewables portfolio standards: Experience from the United States. Energy Policy, 39(7), 3894-3905. doi: 10.1016/j.enpol.2010.11.025

Wolsink, M. (2000). Wind power and the NIMBY-myth: institutional capacity and the limited significance of public support. Renewable Energy, 21(1), 49-64. doi: http://dx.doi.org/10.1016/S0960-1481(99)00130-5

Woody, T. (2011, February 24, 2011). Solar Energy Faces Tests on Greeness. New York Times, p. B1.

Woody, T. (2012). Sierra Club, NRDC Sue Feds to Stop Big California Solar Power Plant. Forbes. Retrieved from

World Electricity Production from All Energy Sources in 2012 (TWh). (2012, May 20, 2015). Retrieved from http://www.tsp-data-portal.org/

Wüstenhagen, R., Wolsink, M., \& Bürer, M. J. (2007). Social acceptance of renewable energy innovation: An introduction to the concept. Energy Policy, 35(5), 2683-2691. doi: 10.1016/j.enpol.2006.12.001

Zoellner, J., Schweizer-Ries, P., \& Wemheuer, C. (2008). Public acceptance of renewable energies: Results from case studies in Germany. Energy Policy, 36(11), 4136-4141. doi:

http://dx.doi.org/10.1016/j.enpol.2008.06.026

Zweibel, K., Mason, J., \& Fthenakis, V. (2008). A solar grand plan. Scientific American, 298(1), 64-73. 
APPENDIX A: DATABASE BASE TOPICS 


\begin{tabular}{|c|c|c|c|c|c|c|}
\hline \multicolumn{7}{|c|}{ BASE TOPICS } \\
\hline Project Name & Org. Project Name & Current Owner & $\begin{array}{l}\text { Change of } \\
\text { Ownership }\end{array}$ & Original Owner & Power Purchaser & Project Status \\
\hline Abengoa Mojave Solar & & Abengoa & No & & Pacific Gas \& Electric & Under Construction \\
\hline Adame 1 & & Gestamp Asetym Solar North America, Inc. & No & & & Under Review \\
\hline Alpaugh 50 & & Consolidated Edison Development & Yes & Solar Power Solutions & Pacific Gas \& Electric & Operating \\
\hline Alpine Solar Project & & First Solar & No & & Pacific Gas \& Electric & Operating \\
\hline AV Solar Ranch One & & First Solar & No & & Pacific Gas \& Electric & Operating \\
\hline Avenal Photovoltaic Solar Farm & & NRG Solar & No & & Pacific Gas \& Electric & Operating \\
\hline AVSP 1 \&2 & & MidAmerican Solar & Yes & SunPower & Southern California Edison & Under Construction \\
\hline Barren Ridge Solar & & Recurrent Energy & No & & & Under Development \\
\hline Barren Ridge Solar & & enXco & No & & & Under Review \\
\hline Beacon Photovoltaic Project & Beacon Solar Energy Project & Beacon Solar LLC & No & & Los Angeles Department of Power \& Water & Under Revision \\
\hline Bechtel Soda Mountain Solar Project & & Caithness & No & & & Under Review \\
\hline Beltran Ranch Solar Facility & & Alternative Energy Group, Inc. & No & & & Under Development \\
\hline Blythe Solar Power Project & & NextEra Energy Resources & Yes & Solar Millennium & Southern California Edison & Under Revision \\
\hline Broadwell SEGS & Siberia SEGS & BrightSource Energy & No & & & On Hold \\
\hline Cal City Solar & & enXco & No & & & Under Review \\
\hline Calexico Solar Farm 1 & & 8minuteenergy & No & & San Diego Gas \& Electric & Under Development \\
\hline Calexico Solar Farm 2 & & 8minuteenergy & No & & San Diego Gas \& Electric & Under Development \\
\hline Calico Solar Project I & SEGS Solar Three & K Road Solar & Yes & Tessera Solar & Southern California Edison & Canceled \\
\hline California Valley Solar Ranch & & NRG Energy & No & & Pacific Gas \& Electric & Operating \\
\hline Calipatria Solar Farm I & & 8minuteenergy & No & & San Diego Gas \& Electric & On Hold \\
\hline Campo Verde & & Southern Power and Turner Renewable Energy & Yes & First Solar & San Diego Gas \& Electric & Under Construction \\
\hline Carrizo Energy Solar Farm & & First Solar & Yes & Ausra CA II,LLC & & Canceled \\
\hline Catalina Solar Project & & EDF Renewables & No & & San Diego Gas \& Electric & Operating \\
\hline Centinela Solar Energy & & LS Power & No & & San Diego Gas \& Electric & Under Construction \\
\hline Central Antelope Dry Ranch & Antelope Solar Greenworks & Silverado Power & No & & Pacific Gas \& Electric & Under Review \\
\hline Desert Harvest & & EDF Renewables & No & & & Under Development \\
\hline Desert Sunlight & & First Solar & No & & Southern California Edison & Under Construction \\
\hline Fink Road Solar Farm & & Golden Hills Solar & No & & & Under Development \\
\hline Five Points Solar Park & & Frontier Renewables, LLC & No & & Pacific Gas \& Electric & Under Review \\
\hline Fort Irwin Solar Power Project & & Acciona & No & & U.S. Army/surrounding utilities & Under Review \\
\hline Gateway Solar Project & & East Kern Properties, LLC & No & & & Under Review \\
\hline Genesis Solar Energy Project & & NextEra Energy Resources & No & & Pacific Gas \& Electric & Under Construction \\
\hline Gray Butte Solar Array Project & & Gray Butte Solar, LLC & No & & & Under Review \\
\hline Harper Lake Solar Plant & SEGS IX \& X & NextEra Energy Resources & Yes & Luz & Southern California Edison & Operating \\
\hline Henrietta Solar Project & & SunPower & No & & Pacific Gas \& Electric & Under Development \\
\hline Hidden Hills Solar Electric Generating System & & BrightSource Energy & No & & Pacific Gas \& Electric & On Hold \\
\hline Imperial Solar Energy Center South & & Tenaska & No & & San Diego Gas \& Electric & Operating \\
\hline Imperial Solar Energy Center West & & Tenaska & No & & San Diego Gas \& Electric & Under Development \\
\hline Imperial Valley Solar Project & SES Solar Two & AES Solar & Yes & Tessera & San Diego Gas \& Electric & Under Development \\
\hline Inspiration Solar Generation Farm & & Silverado Power & No & & & Under Review \\
\hline Ivanpah Solar Electric Generating System & & BrightSource Energy & No & & Pacific Gas \& Electric & Operating \\
\hline
\end{tabular}




\begin{tabular}{|c|c|c|c|c|c|c|}
\hline \multicolumn{7}{|c|}{ BASE TOPICS } \\
\hline Project Name & Org. Project Name & Current Owner & $\begin{array}{l}\text { Change of } \\
\text { Ownership }\end{array}$ & Original Owner & Power Purchaser & Project Status \\
\hline Johnson Valley SEGS & & Johnson Valley SEGS, LLC & No & & & Under Review \\
\hline Kern Solar Ranch & & Kern Solar, LLC & No & & Pacific Gas \& Electric & Under Review \\
\hline Kramer Junction SEGS & SEGS III, IV, V, VI, VII & NextEra Energy Resources & Yes & Luz & Southern California Edison & Operating \\
\hline Liberty Solar Generation Project & & Silverado Power & No & & & Under Review \\
\hline Lotus Solar Farm & & 8minuteenergy & No & & & Under Development \\
\hline McCoy Solar Energy Center & & NextEra Energy Resources & No & & & Under Development \\
\hline Midway Solar Farm 1 & & 8minuteenergy & No & & & Under Development \\
\hline Midway Solar Farm 2 & & 8minuteenergy & No & & & Under Development \\
\hline Monte Vista Solar Array & & First Solar & No & & & Under Review \\
\hline Mount Signal Solar Farm & & AES Solar & Yes & 8minuteenergy & San Diego Gas \& Electric & Under Construction \\
\hline Mountain House Solar Farm & & Pegasus Energy Partners & No & & & Canceled \\
\hline Mustang & & Recurrent Energy & No & & & Under Development \\
\hline North Star Power 1 & North Star Solar Array Project & First Solar & Yes & North Star Solar & Pacific Gas \& Electric & Under Development \\
\hline North Valley Solar Generation Project & & Silverado Power, LLC & No & & & Under Development \\
\hline Oro Verde Solar & & Sun Edison & No & & & Under Review \\
\hline Palen Solar Power Project & & BrightSource Energy & No & & Southern California Edison & Under Development \\
\hline Panoche Valley Solar Farm & & PV2 Energy & Yes & Solargen & & Under Development \\
\hline Quinto Solar Photovoltaic Project & & SunPower & No & & Southern California Edison & Under Development \\
\hline Regulus Solar & FRV Valley Solar Project & SunEdison & No & & Southern California Edison & Canceled \\
\hline Rice Solar Energy Project & & SolarReserve & No & & Pacific Gas \& Electric & Under Development \\
\hline Ridgecrest & & Solar Trust America & Yes & Solarhybrid & & On Hold \\
\hline Rio Mesa Solar Electric Generating Facility & & BrightSource Energy & No & & & Canceled \\
\hline Riverbluff Solar Energy Park & & TerraGen & No & & & Under Development \\
\hline Rosamond Solar & & Sempra Generation & No & & & Under Development \\
\hline Rosamond Solar Array & & First Solar & No & & & Under Review \\
\hline Rugged Solar Farm & & Soitec & No & & San Diego Gas \& Electric & Under Review \\
\hline Salton Sea Solar Farm 1 & & 8minuteenergy & No & & & On Hold \\
\hline Salton Sea Solar Farm 2 & & 8minuteenergy & No & & & On Hold \\
\hline Silverleaf & & Agile & Yes & Tenaska & San Diego Gas \& Electric & Under Review \\
\hline Solargen Panoche Valley Solar Farm & & PV2 Energy & Yes & Solargen & Pacific Gas \& Electric & In Litigation \\
\hline Sonoran West & & BrightSource Energy & No & & Southern California Edison & Under Development \\
\hline Springbok Solar & & 8minuteenergy & No & & & Under Development \\
\hline Stateline Solar Farm & & First Solar & No & & Southern California Edison & Under Development \\
\hline Tierra del Sol & & Soitec & No & & San Diego Gas \& Electric & Under Review \\
\hline Topaz Solar Farm & & First Solar & No & & Pacific Gas \& Electric & Under Construction \\
\hline Tranquillity Solar Generating Facility & & RE Tranquillity LLC & No & & & Under Review \\
\hline Westlands Solar Park & & Westside Holdings & No & & & Under Review \\
\hline Westside Solar Ranch & & Frontier Solar, LLC & Yes & Scatec Solar & Pacific Gas \& Electric & Under Development \\
\hline Willow Springs Solar Array & & First Solar & No & & Southern California Edison & Under Review \\
\hline
\end{tabular}




\section{APPENDIX B: DATABASE LOCATION TOPICS}




\begin{tabular}{|c|c|c|}
\hline \multicolumn{3}{|c|}{ LOCATION TOPICS } \\
\hline Project Name & County & Nearest City \\
\hline Abengoa Mojave Solar & San Bernardino & Lockhart \\
\hline Adame 1 & Fresno & Mendota \\
\hline Alpaugh 50 & Tulare & Alpaugh \\
\hline Alpine Solar Project & Los Angeles & Rosamond \\
\hline AV Solar Ranch One & Los Angeles & Antelope Valley \\
\hline Avenal Photovoltaic Solar Farm & Kings & Avenal \\
\hline AVSP 1 \&2 & Los Angeles & Los Banos \\
\hline Barren Ridge Solar & Kern & California City \\
\hline Barren Ridge Solar & Kern & California City \\
\hline Beacon Photovoltaic Project & Kern & Cantil \\
\hline Bechtel Soda Mountain Solar Project & San Bernardino & Baker \\
\hline Beltran Ranch Solar Facility & Stanislaus & Newman \\
\hline Blythe Solar Power Project & Riverside & Blythe \\
\hline Broadwell SEGS & San Bernardino & Broadwell Dry Lake \\
\hline Cal City Solar & Kern & California City \\
\hline Calexico Solar Farm 1 & Imperial Valley & Calexico \\
\hline Calexico Solar Farm 2 & Imperial Valley & Calexico \\
\hline Calico Solar Project I & San Bernardino & Barstow \\
\hline California Valley Solar Ranch & San Luis Obispo & California Valley \\
\hline Calipatria Solar Farm I & Imperial & Calipatria \\
\hline Campo Verde & Imperial & El Centro \\
\hline Carrizo Energy Solar Farm & San Luis Obispo & Simmler \\
\hline Catalina Solar Project & Kern & Bakersfield \\
\hline Centinela Solar Energy & Imperial Valley & El Centro \\
\hline Central Antelope Dry Ranch & Los Angeles & Lancaster \\
\hline Desert Harvest & Riverside & Desert Center \\
\hline Desert Sunlight & Riverside & Desert Center \\
\hline Fink Road Solar Farm & Stanislaus & Newman \\
\hline Five Points Solar Park & Fresno & Five Points \\
\hline Fort Irwin Solar Power Project & San Bernardino & Ft. Irwin \\
\hline Gateway Solar Project & Kern & California City \\
\hline Genesis Solar Energy Project & Riverside & Blythe \\
\hline Gray Butte Solar Array Project & Los Angeles & Palmdale \\
\hline Harper Lake Solar Plant & San Bernardino & Harper Dry Lake \\
\hline Henrietta Solar Project & Kings & Stratford \\
\hline Hidden Hills Solar Electric Generating System & Inyo & Tecopa \\
\hline Imperial Solar Energy Center South & Imperial & Mount Signal \\
\hline Imperial Solar Energy Center West & Imperial & Ocotillo \\
\hline Imperial Valley Solar Project & Imperial & Ocotillo \\
\hline Inspiration Solar Generation Farm & Fresno & Kerman \\
\hline Ivanpah Solar Electric Generating System & San Bernardino & Barstow \\
\hline Johnson Valley SEGS & San Bernardino & \\
\hline Kern Solar Ranch & Kern & Blackwells Corner \\
\hline Kramer Junction SEGS & San Bernardino & Kramer Junction \\
\hline
\end{tabular}




\begin{tabular}{|c|c|c|}
\hline \multicolumn{3}{|c|}{ LOCATION TOPICS } \\
\hline Project Name & County & Nearest City \\
\hline Liberty Solar Generation Project & Fresno & Mendota \\
\hline Lotus Solar Farm & Madera & Madera \\
\hline McCoy Solar Energy Center & Riverside & Blythe \\
\hline Midway Solar Farm 1 & Imperial Valley & Calipatria \\
\hline Midway Solar Farm 2 & Imperial Valley & Calipatria \\
\hline Monte Vista Solar Array & Kern & California City \\
\hline Mount Signal Solar Farm & Imperial & Calexico \\
\hline Mountain House Solar Farm & Alameda & Mountain House \\
\hline Mustang & Kings & Lemoore \\
\hline North Star Power 1 & Fresno & Mendota \\
\hline North Valley Solar Generation Project & Fresno & Fresno \\
\hline Oro Verde Solar & Kern & Mojave \\
\hline Palen Solar Power Project & Riverside & Desert Center \\
\hline Panoche Valley Solar Farm & San Benito & Soledad \\
\hline Quinto Solar Photovoltaic Project & Merced & Los Banos \\
\hline Regulus Solar & Kern & Bakersfield \\
\hline Rice Solar Energy Project & Riverside & Vidal Junction \\
\hline Ridgecrest & Kern & Ridgecrest \\
\hline Rio Mesa Solar Electric Generating Facility & Riverside & Blythe \\
\hline Riverbluff Solar Energy Park & San Bernardino & Newberry Springs \\
\hline Rosamond Solar & Kern & Rosamond \\
\hline Rosamond Solar Array & Kern & Rosamond \\
\hline Rugged Solar Farm & San Diego & Boulevard \\
\hline Salton Sea Solar Farm 1 & Imperial Valley & Calipatria \\
\hline Salton Sea Solar Farm 2 & Imperial Valley & Calipatria \\
\hline Silverleaf & Imperial Valley & El Centro \\
\hline Solargen Panoche Valley Solar Farm & Panoche Hills & San Benito \\
\hline Sonoran West & Riverside & Palo Verde Mesa \\
\hline Springbok Solar & Kern & Cantil \\
\hline Stateline Solar Farm & San Bernardino & Primm, NV \\
\hline Tierra del Sol & San Diego & \\
\hline Topaz Solar Farm & San Luis Obispo & California Valley \\
\hline Tranquillity Solar Generating Facility & Fresno & Tranquillity \\
\hline Westlands Solar Park & Kings & Lemoore \\
\hline Westside Solar Ranch & Stanislaus & Newman \\
\hline Willow Springs Solar Array & Kern & Willow Springs \\
\hline
\end{tabular}




\section{APPENDIX C: DATABASE TECHNOLOGY TOPICS}




\begin{tabular}{|c|c|c|c|c|}
\hline \multicolumn{5}{|c|}{ TECHNOLOGY TOPICS } \\
\hline Project Name & Original PV/CSP & $\begin{array}{l}\text { Current } \\
\text { PV/CSP }\end{array}$ & Switch CSP/PV & $\begin{array}{c}\text { Generation } \\
\text { Capacity }\end{array}$ \\
\hline Abengoa Mojave Solar & CSP & CSP & No & 250 \\
\hline Adame 1 & PV & $\mathrm{PV}$ & No & 119 \\
\hline Alpaugh 50 & PV & PV & No & 50 \\
\hline Alpine Solar Project & PV & PV & No & 66 \\
\hline AV Solar Ranch One & PV & PV & No & 115 \\
\hline Avenal Photovoltaic Solar Farm & PV & PV & No & 600 \\
\hline AVSP $1 \& 2$ & PV & PV & No & 579 \\
\hline Barren Ridge Solar & PV & PV & No & 74 \\
\hline Barren Ridge Solar & PV & PV & No & 100 \\
\hline Beacon Photovoltaic Project & CSP & PV & Yes & 250 \\
\hline Bechtel Soda Mountain Solar Project & $\mathrm{PV}$ & PV & No & 350 \\
\hline Beltran Ranch Solar Facility & PV & PV & No & 140 \\
\hline Blythe Solar Power Project & CSP & PV & Yes & 486 \\
\hline Broadwell SEGS & CSP & CSP & No & 1000 \\
\hline Cal City Solar & PV & PV & No & 100 \\
\hline Calexico Solar Farm 1 & PV & PV & No & 200 \\
\hline Calexico Solar Farm 2 & PV & PV & No & 200 \\
\hline Calico Solar Project I & CSP & PV & Yes & 618 \\
\hline California Valley Solar Ranch & PV & PV & No & 250 \\
\hline Calipatria Solar Farm I & PV & PV & No & 70 \\
\hline Campo Verde & PV & PV & No & 139 \\
\hline Carrizo Energy Solar Farm & CSP & PV & Yes & 177 \\
\hline Catalina Solar Project & PV & PV & No & 143 \\
\hline Centinela Solar Energy & PV & PV & No & 275 \\
\hline Central Antelope Dry Ranch & PV & PV & No & 52 \\
\hline Desert Harvest & PV & PV & No & 150 \\
\hline Desert Sunlight & PV & PV & No & 550 \\
\hline Fink Road Solar Farm & PV & PV & No & 80 \\
\hline Five Points Solar Park & PV & PV & No & 69 \\
\hline
\end{tabular}




\begin{tabular}{|c|c|c|c|c|}
\hline \multicolumn{5}{|c|}{ TECHNOLOGY TOPICS } \\
\hline Project Name & Original PV/CSP & $\begin{array}{l}\text { Current } \\
\text { PV/CSP }\end{array}$ & Switch CSP/PV & $\begin{array}{c}\text { Generation } \\
\text { Capacity }\end{array}$ \\
\hline Fort Irwin Solar Power Project & CSP & CSP & No & 500 \\
\hline Gateway Solar Project & PV & PV & No & 350 \\
\hline Genesis Solar Energy Project & CSP & CSP & No & 125 \\
\hline Gray Butte Solar Array Project & PV & $\mathrm{PV}$ & No & 150 \\
\hline Harper Lake Solar Plant & CSP & CSP & No & 250 \\
\hline Henrietta Solar Project & PV & PV & No & 136 \\
\hline Hidden Hills Solar Electric Generating System & CSP & CSP & No & 500 \\
\hline Imperial Solar Energy Center South & PV & PV & No & 130 \\
\hline Imperial Solar Energy Center West & PV & PV & No & 150 \\
\hline Imperial Valley Solar Project & CSP & PV & Yes & 709 \\
\hline Inspiration Solar Generation Farm & PV & PV & No & 60 \\
\hline Ivanpah Solar Electric Generating System & CSP & CSP & No & 370 \\
\hline Johnson Valley SEGS & CSP & CSP & No & 800 \\
\hline Kern Solar Ranch & PV & PV & No & 1000 \\
\hline Kramer Junction SEGS & CSP & CSP & No & 150 \\
\hline Liberty Solar Generation Project & PV & PV & No & 60 \\
\hline Lotus Solar Farm & PV & PV & No & 90 \\
\hline McCoy Solar Energy Center & PV & PV & No & 750 \\
\hline Midway Solar Farm 1 & PV & PV & No & 50 \\
\hline Midway Solar Farm 2 & PV & PV & No & 155 \\
\hline Monte Vista Solar Array & PV & PV & No & 126 \\
\hline Mount Signal Solar Farm & PV & PV & No & 200 \\
\hline Mountain House Solar Farm & PV & PV & No & 400 \\
\hline Mustang & PV & PV & No & 160 \\
\hline North Star Power 1 & PV & PV & No & 60 \\
\hline North Valley Solar Generation Project & PV & PV & No & 90 \\
\hline Oro Verde Solar & PV & PV & No & 450 \\
\hline Palen Solar Power Project & CSP & CSP & No & 500 \\
\hline Panoche Valley Solar Farm & PV & PV & No & 420 \\
\hline Quinto Solar Photovoltaic Project & PV & PV & No & 110 \\
\hline
\end{tabular}




\begin{tabular}{|c|c|c|c|c|}
\hline \multicolumn{5}{|c|}{ TECHNOLOGY TOPICS } \\
\hline Project Name & Original PV/CSP & $\begin{array}{l}\text { Current } \\
\text { PV/CSP }\end{array}$ & Switch CSP/PV & $\begin{array}{c}\text { Generation } \\
\text { Capacity }\end{array}$ \\
\hline Regulus Solar & PV & PV & No & 75 \\
\hline Rice Solar Energy Project & CSP & CSP & No & 150 \\
\hline Ridgecrest & CSP & CSP & No & 250 \\
\hline Rio Mesa Solar Electric Generating Facility & CSP & CSP & No & 500 \\
\hline Riverbluff Solar Energy Park & PV & PV & No & 230 \\
\hline Rosamond Solar & PV & $\mathrm{PV}$ & No & 300 \\
\hline Rosamond Solar Array & PV & PV & No & 155 \\
\hline Rugged Solar Farm & PV & PV & No & 80 \\
\hline Salton Sea Solar Farm 1 & PV & PV & No & 50 \\
\hline Salton Sea Solar Farm 2 & PV & PV & No & 100 \\
\hline Silverleaf & PV & PV & No & 160 \\
\hline Solargen Panoche Valley Solar Farm & PV & PV & No & 400 \\
\hline Sonoran West & CSP & CSP & No & 540 \\
\hline Springbok Solar & PV & PV & No & 150 \\
\hline Stateline Solar Farm & PV & PV & No & 300 \\
\hline Tierra del Sol & PV & PV & No & 60 \\
\hline Topaz Solar Farm & PV & PV & No & 550 \\
\hline Tranquillity Solar Generating Facility & PV & PV & No & 400 \\
\hline Westlands Solar Park & PV & PV & No & 2400 \\
\hline Westside Solar Ranch & PV & PV & No & 50 \\
\hline Willow Springs Solar Array & PV & PV & No & 160 \\
\hline
\end{tabular}




\section{APPENDIX D: DATABASE LAND USE TOPICS}




\begin{tabular}{|c|c|c|c|c|}
\hline \multicolumn{5}{|c|}{ LAND USE TOPICS } \\
\hline Project Name & $\begin{array}{l}\text { Original Land } \\
\text { Ownership }\end{array}$ & $\begin{array}{c}\text { Original Land } \\
\text { Use }\end{array}$ & $\begin{array}{l}\text { Total Site } \\
\text { Acreage }\end{array}$ & $\begin{array}{c}\text { Developed Site } \\
\text { Acreage }\end{array}$ \\
\hline Abengoa Mojave Solar & Public & Agriculture & 1765 & 1765 \\
\hline Adame 1 & Private & Agriculture & 960 & 960 \\
\hline Alpaugh 50 & Public & Agriculture & 740 & 390.5 \\
\hline Alpine Solar Project & Private & Agriculture & 800 & 580 \\
\hline AV Solar Ranch One & Private & Agriculture & 2100 & 2100 \\
\hline Avenal Photovoltaic Solar Farm & Private & Agriculture & 420 & 420 \\
\hline AVSP 1 \&2 & Private & Residential & 3200 & 3200 \\
\hline Barren Ridge Solar & Private & Agriculture & 588 & 588 \\
\hline Barren Ridge Solar & Private & Agriculture & 647 & 611 \\
\hline Beacon Photovoltaic Project & Private & Agriculture & 2012 & $\mathrm{~N} / \mathrm{A}$ \\
\hline Bechtel Soda Mountain Solar Project & Public & BLM & 4397 & 2700 \\
\hline Beltran Ranch Solar Facility & Private & Agriculture & 1720 & 606 \\
\hline Blythe Solar Power Project & Public & BLM & 9400 & 5950 \\
\hline Broadwell SEGS & Public & BLM & 5130 & 5130 \\
\hline Cal City Solar & Private & Agriculture & 638 & 548 \\
\hline Calexico Solar Farm 1 & Private & Agriculture & 1332 & 1332 \\
\hline Calexico Solar Farm 2 & Private & Agriculture & 1465 & 1465 \\
\hline Calico Solar Project I & Public & BLM & 8230 & 4613 \\
\hline California Valley Solar Ranch & Private & Agriculture & 1966 & 4365 \\
\hline Calipatria Solar Farm I & Private & Agriculture & 609 & 582 \\
\hline Campo Verde & Public/Private & Agriculture & 1900 & 1852 \\
\hline Carrizo Energy Solar Farm & Private & Agriculture & 640 & 640 \\
\hline Catalina Solar Project & Private & Agriculture & 4571 & 900 \\
\hline Centinela Solar Energy & Public /Private & Agriculture & 2067 & 2067 \\
\hline Central Antelope Dry Ranch & Private & Agriculture & 256 & 256 \\
\hline Desert Harvest & Federal & BLM & 1208 & 1208 \\
\hline Desert Sunlight & Federal & BLM & 4090 & 4090 \\
\hline Fink Road Solar Farm & Public & Landfill & 1687 & 800 \\
\hline Five Points Solar Park & Private & Agriculture & 499 & 499 \\
\hline
\end{tabular}




\begin{tabular}{|c|c|c|c|c|}
\hline \multicolumn{5}{|c|}{ LAND USE TOPICS } \\
\hline Project Name & $\begin{array}{c}\text { Original Land } \\
\text { Ownership }\end{array}$ & $\begin{array}{c}\text { Original Land } \\
\text { Use }\end{array}$ & $\begin{array}{c}\text { Total Site } \\
\text { Acreage }\end{array}$ & $\begin{array}{c}\text { Developed Site } \\
\text { Acreage }\end{array}$ \\
\hline Fort Irwin Solar Power Project & Federal & Military & $N / A$ & $N / A$ \\
\hline Gateway Solar Project & Private & Agriculture & 3066 & 3066 \\
\hline Genesis Solar Energy Project & Federal & BLM & 1800 & 1800 \\
\hline Gray Butte Solar Array Project & Private & Agriculture & 1100 & 1100 \\
\hline Harper Lake Solar Plant & Public & Agriculture & 400 & 400 \\
\hline Henrietta Solar Project & Private & Agriculture & 903 & 836 \\
\hline Hidden Hills Solar Electric Generating System & Private & Agriculture & 3277 & 3277 \\
\hline Imperial Solar Energy Center South & Private & Agriculture & 946 & 946 \\
\hline Imperial Solar Energy Center West & Private & Agriculture & 1103 & 1103 \\
\hline Imperial Valley Solar Project & Public & BLM & 6360 & 6360 \\
\hline Inspiration Solar Generation Farm & Private & Agriculture & 292 & 292 \\
\hline Ivanpah Solar Electric Generating System & Public & BLM & 3400 & 3400 \\
\hline Johnson Valley SEGS & Public & BLM & 1560 & 1560 \\
\hline Kern Solar Ranch & Private & Agriculture & 14400 & 6100 \\
\hline Kramer Junction SEGS & Private & Unknown & 1000 & 1000 \\
\hline Liberty Solar Generation Project & Private & Agriculture & 321 & 321 \\
\hline Lotus Solar Farm & Private & Agriculture & 459 & 459 \\
\hline McCoy Solar Energy Center & Public & BLM & 2259 & 2259 \\
\hline Midway Solar Farm 1 & Private & Agriculture & 326 & 326 \\
\hline Midway Solar Farm 2 & Private & Agriculture & 803 & 803 \\
\hline Monte Vista Solar Array & Private & Agriculture & 1040 & 1040 \\
\hline Mount Signal Solar Farm & Private & Agriculture & 1431 & 1431 \\
\hline Mountain House Solar Farm & Private & Agriculture & 2000 & 2000 \\
\hline Mustang & Private & Agriculture & 1002 & 1002 \\
\hline North Star Power 1 & Private & Agriculture & 640 & 640 \\
\hline North Valley Solar Generation Project & Private & Agriculture & 489 & 489 \\
\hline Oro Verde Solar & Public & Military & 4000 & 2750 \\
\hline Palen Solar Power Project & Public & BLM & 2970 & 2970 \\
\hline Panoche Valley Solar Farm & Private & Agriculture & 4717 & 4717 \\
\hline Quinto Solar Photovoltaic Project & Private & Agriculture & 1012 & 1012 \\
\hline
\end{tabular}




\begin{tabular}{|c|c|c|c|c|}
\hline \multicolumn{5}{|c|}{ LAND USE TOPICS } \\
\hline Project Name & $\begin{array}{l}\text { Original Land } \\
\text { Ownership }\end{array}$ & $\begin{array}{c}\text { Original Land } \\
\text { Use }\end{array}$ & $\begin{array}{l}\text { Total Site } \\
\text { Acreage }\end{array}$ & $\begin{array}{c}\text { Developed Site } \\
\text { Acreage }\end{array}$ \\
\hline Regulus Solar & Private & Agriculture & 743 & 743 \\
\hline Rice Solar Energy Project & Private & Military & 3324 & 3324 \\
\hline Ridgecrest & Public & BLM & 3995 & 2000 \\
\hline Rio Mesa Solar Electric Generating Facility & Private & Agriculture & 4070 & 4070 \\
\hline Riverbluff Solar Energy Park & Private & Agriculture & 1500 & 1500 \\
\hline Rosamond Solar & Private & Agriculture & 960 & 960 \\
\hline Rosamond Solar Array & Private & Agriculture & 1177 & 1177 \\
\hline Rugged Solar Farm & Private & Agriculture & 765 & 765 \\
\hline Salton Sea Solar Farm 1 & Private & Agriculture & 320 & 320 \\
\hline Salton Sea Solar Farm 2 & Private & Agriculture & 640 & 640 \\
\hline Silverleaf & Private & Agriculture & 1096 & 1096 \\
\hline Solargen Panoche Valley Solar Farm & Private & Agriculture & 4885 & 2437 \\
\hline Sonoran West & Private & BLM & 12269 & 12269 \\
\hline Springbok Solar & Private & Agriculture & 951 & 951 \\
\hline Stateline Solar Farm & Private & BLM & 1685 & 2385 \\
\hline Tierra del Sol & Private & Agriculture & 420 & 420 \\
\hline Topaz Solar Farm & Private & Agriculture & 7800 & 4000 \\
\hline Tranquillity Solar Generating Facility & Public/Private & Agriculture & 3732 & 3732 \\
\hline Westlands Solar Park & Private & Agriculture & 24000 & 2400 \\
\hline Westside Solar Ranch & Private & Agriculture & 1132 & 382 \\
\hline Willow Springs Solar Array & Private & Agriculture & 1402 & 1402 \\
\hline
\end{tabular}


APPENDIX E: DATABASE JURISDICTION AND PROCESS TOPICS 


\begin{tabular}{|c|c|c|c|c|c|c|}
\hline & \multicolumn{2}{|c|}{ JURISDICTION TOPICS } & \multicolumn{4}{|c|}{ PROCESS TOPICS } \\
\hline Project Name & $\begin{array}{c}\text { Original } \\
\text { Jurisdiction }\end{array}$ & $\begin{array}{l}\text { Current } \\
\text { Jurisdiction }\end{array}$ & $\begin{array}{c}\text { Initial } \\
\text { Study } \\
\text { Completed }\end{array}$ & $\begin{array}{l}\text { ElR/EIS } \\
\text { Required }\end{array}$ & $\begin{array}{c}\text { Negative } \\
\text { Declaration }\end{array}$ & $\begin{array}{l}\text { Approval } \\
\text { Status }\end{array}$ \\
\hline Abengoa Mojave Solar & CEC & CEC & CEC & Yes & No & Yes \\
\hline Adame 1 & County & County & Yes & No & Mitigated & In Process \\
\hline Alpaugh 50 & County & County & Yes & No & Mitigated & Yes \\
\hline Alpine Solar Project & County & County & Yes & No & Mitigated & Yes \\
\hline AV Solar Ranch One & County & County & Yes & Yes & No & Yes \\
\hline Avenal Photovoltaic Solar Farm & County & County & Yes & No & Mitigated & Yes \\
\hline AVSP $1 \& 2$ & County & County & Yes & Yes & No & Yes \\
\hline Barren Ridge Solar & County & County & Yes & Yes & No & Yes \\
\hline Barren Ridge Solar & County & County & No & Yes & No & In Process \\
\hline Beacon Photovoltaic Project & CEC & County & No & Yes & No & Yes \\
\hline Bechtel Soda Mountain Solar Project & BLM & BLM & NEPA & EIS & No & In Process \\
\hline Beltran Ranch Solar Facility & County & County & Yes & No & Mitigated & Yes \\
\hline Blythe Solar Power Project & CEC & BLM & CEC/NEPA & EIS & No & Yes \\
\hline Broadwell SEGS & CEC/BLM & CEC/BLM & NEPA & EIS & No & On Hold \\
\hline Cal City Solar & County & County & No & Yes & No & In Process \\
\hline Calexico Solar Farm 1 & County & County & Yes & Yes & No & Yes \\
\hline Calexico Solar Farm 2 & County & County & Yes & Yes & No & Yes \\
\hline Calico Solar Project I & CEC & County & CEC & Yes & No & Yes \\
\hline California Valley Solar Ranch & County & County & Yes & Yes & No & Yes \\
\hline Calipatria Solar Farm I & County & County & Yes & Yes & No & Yes \\
\hline Campo Verde & County & County & Yes & Yes & No & Yes \\
\hline Carrizo Energy Solar Farm & CEC & County & CEC & Yes & No & No \\
\hline Catalina Solar Project & County & County & Yes & Yes & No & Yes \\
\hline Centinela Solar Energy & County & County & Yes & Yes & No & Yes \\
\hline Central Antelope Dry Ranch & County & County & Yes & Yes & No & In Process \\
\hline Desert Harvest & BLM & BLM & NEPA & EIS & No & Yes \\
\hline Desert Sunlight & BLM & BLM & NEPA & EIS & No & Yes \\
\hline Fink Road Solar Farm & County & County & Yes & No & Mitigated & Yes \\
\hline
\end{tabular}




\begin{tabular}{|c|c|c|c|c|c|c|}
\hline & \multicolumn{2}{|c|}{ JURISDICTION TOPICS } & \multicolumn{4}{|c|}{ PROCESS TOPICS } \\
\hline Project Name & $\begin{array}{c}\text { Original } \\
\text { Jurisdiction }\end{array}$ & $\begin{array}{l}\text { Current } \\
\text { Jurisdiction }\end{array}$ & $\begin{array}{c}\text { Initial } \\
\text { Study } \\
\text { Completed }\end{array}$ & $\begin{array}{l}\text { EIR/EIS } \\
\text { Required }\end{array}$ & $\begin{array}{c}\text { Negative } \\
\text { Declaration }\end{array}$ & $\begin{array}{c}\text { Approval } \\
\text { Status }\end{array}$ \\
\hline Five Points Solar Park & County & County & Yes & $\mathrm{N} / \mathrm{A}$ & $\mathrm{N} / \mathrm{A}$ & In Process \\
\hline Fort Irwin Solar Power Project & Army & Army & NEPA & EIS & No & In Process \\
\hline Gateway Solar Project & County & County & $\mathrm{N} / \mathrm{A}$ & Yes & $\mathrm{N} / \mathrm{A}$ & In Process \\
\hline Genesis Solar Energy Project & CEC/BLM & CEC/BLM & CEC/NEPA & Yes & No & Yes \\
\hline Gray Butte Solar Array Project & County & County & Yes & Yes & No & In Process \\
\hline Harper Lake Solar Plant & State & State & State & $\mathrm{N} / \mathrm{A}$ & No & Unknown \\
\hline Henrietta Solar Project & County & County & Yes & No & Mitigated & Yes \\
\hline Hidden Hills Solar Electric Generating System & CEC & CEC & CEC & Yes & No & On Hold \\
\hline Imperial Solar Energy Center South & County & County & No & Yes & No & Yes \\
\hline Imperial Solar Energy Center West & County & County & No & Yes & No & Yes \\
\hline Imperial Valley Solar Project & CEC & BLM & No & Yes & No & Yes \\
\hline Inspiration Solar Generation Farm & County & County & Yes & No & Mitigated & In Process \\
\hline Ivanpah Solar Electric Generating System & CEC & CEC & CEC & Yes & No & Yes \\
\hline Johnson Valley SEGS & CEC/BLM & CEC/BLM & CEC/NEPA & Yes & No & In Process \\
\hline Kern Solar Ranch & County & County & Yes & Yes & No & In Process \\
\hline Kramer Junction SEGS & State & State & $\mathrm{N} / \mathrm{A}$ & $\mathrm{N} / \mathrm{A}$ & No & Yes \\
\hline Liberty Solar Generation Project & County & County & Yes & No & Mitigated & In Process \\
\hline Lotus Solar Farm & County & County & Yes & No & Mitigated & Yes \\
\hline McCoy Solar Energy Center & BLM & BLM & NEPA & EIS & No & Yes \\
\hline Midway Solar Farm 1 & County & County & Yes & Yes & No & Yes \\
\hline Midway Solar Farm 2 & County & County & Yes & Yes & No & Yes \\
\hline Monte Vista Solar Array & County & County & Yes & Yes & No & In Process \\
\hline Mount Signal Solar Farm & County & County & Yes & Yes & No & Yes \\
\hline Mountain House Solar Farm & County & County & $\mathrm{N} / \mathrm{A}$ & Yes & $N / A$ & Canceled \\
\hline Mustang & County & County & Yes & No & Mitigated & Yes \\
\hline North Star Power 1 & County & County & Yes & No & Mitigated & Yes \\
\hline North Valley Solar Generation Project & County & County & $\mathrm{N} / \mathrm{A}$ & Yes & $\mathrm{N} / \mathrm{A}$ & Unknown \\
\hline Oro Verde Solar & County & County & Yes & Yes & No & In Process \\
\hline Palen Solar Power Project & CEC & CEC & CEC & Yes & No & Yes \\
\hline
\end{tabular}




\begin{tabular}{|c|c|c|c|c|c|c|}
\hline & \multicolumn{2}{|c|}{ JURISDICTION TOPICS } & \multicolumn{4}{|c|}{ PROCESS TOPICS } \\
\hline Project Name & $\begin{array}{c}\text { Original } \\
\text { Jurisdiction }\end{array}$ & $\begin{array}{c}\text { Current } \\
\text { Jurisdiction }\end{array}$ & $\begin{array}{c}\text { Initial } \\
\text { Study } \\
\text { Completed }\end{array}$ & $\begin{array}{l}\text { ElR/EIS } \\
\text { Required }\end{array}$ & $\begin{array}{c}\text { Negative } \\
\text { Declaration }\end{array}$ & $\begin{array}{c}\text { Approval } \\
\text { Status }\end{array}$ \\
\hline Panoche Valley Solar Farm & County & County & No & Yes & No & Yes \\
\hline Quinto Solar Photovoltaic Project & County & County & No & Yes & No & Yes \\
\hline Regulus Solar & County & County & Yes & Yes & No & Yes \\
\hline Rice Solar Energy Project & CEC & CEC & CEC & Yes & No & Yes \\
\hline Ridgecrest & CEC & CEC & CEC & Yes & No & No \\
\hline Rio Mesa Solar Electric Generating Facility & CEC & CEC & CEC & Yes & No & No \\
\hline Riverbluff Solar Energy Park & County & County & Yes & Yes & No & Unknown \\
\hline Rosamond Solar & County & County & Yes & Yes & No & Yes \\
\hline Rosamond Solar Array & County & County & Yes & Yes & No & In Process \\
\hline Rugged Solar Farm & County & County & Yes & Yes & No & In Process \\
\hline Salton Sea Solar Farm 1 & County & County & $\mathrm{N} / \mathrm{A}$ & $\mathrm{N} / \mathrm{A}$ & $\mathrm{N} / \mathrm{A}$ & On Hold \\
\hline Salton Sea Solar Farm 2 & County & County & $\mathrm{N} / \mathrm{A}$ & $\mathrm{N} / \mathrm{A}$ & $\mathrm{N} / \mathrm{A}$ & On Hold \\
\hline Silverleaf & County & County & Yes & Yes & No & In Process \\
\hline Solargen Panoche Valley Solar Farm & County & County & Yes & Yes & No & Yes \\
\hline Sonoran West & CEC & CEC & CEC & Yes & No & Yes \\
\hline Springbok Solar & County & County & Yes & Yes & No & Yes \\
\hline Stateline Solar Farm & BLM & BLM & NEPA & EIS & No & Yes \\
\hline Tierra del Sol & County & County & Yes & Yes & No & In Process \\
\hline Topaz Solar Farm & County & County & Yes & Yes & No & Yes \\
\hline Tranquillity Solar Generating Facility & County & County & Yes & Yes & No & In Process \\
\hline Westlands Solar Park & County & County & Yes & Yes & No & In Process \\
\hline Westside Solar Ranch & County & County & Yes & No & Mitigated & Yes \\
\hline Willow Springs Solar Array & County & County & Yes & Yes & No & In Process \\
\hline
\end{tabular}


APPENDIX F: DATABASE PROCESS TIME TOPICS 


\begin{tabular}{|c|c|c|c|c|c|}
\hline \multicolumn{6}{|c|}{ PROCESS TIME TOPICS } \\
\hline Project Name & $\begin{array}{c}\text { Public } \\
\text { Process Used } \\
\text { For Dates }\end{array}$ & $\begin{array}{c}\text { Total } \\
\text { Process } \\
\text { Time (Days) }\end{array}$ & $\begin{array}{c}\text { Total } \\
\text { Process } \\
\text { Time (Years) }\end{array}$ & $\begin{array}{l}\text { Public Review } \\
\text { Process Start }\end{array}$ & $\begin{array}{c}\text { Public } \\
\text { Review } \\
\text { Process End }\end{array}$ \\
\hline Abengoa Mojave Solar & CEC & 394 & 1.08 & 8/10/2009 & $9 / 8 / 2010$ \\
\hline Adame 1 & EIR & & & $11 / 9 / 2011$ & \\
\hline Alpaugh 50 & EIR & 47 & 0.13 & $8 / 6 / 2010$ & 9/22/2010 \\
\hline Alpine Solar Project & EIR & 301 & 0.82 & $12 / 21 / 2010$ & $10 / 18 / 2011$ \\
\hline AV Solar Ranch One & EIR & 603 & 1.65 & $5 / 14 / 2009$ & $1 / 7 / 2011$ \\
\hline Avenal Photovoltaic Solar Farm & EIR & 42 & 0.12 & $8 / 2 / 2010$ & $9 / 13 / 2010$ \\
\hline AVSP $1 \& 2$ & EIR & 736 & 2.02 & $3 / 8 / 2010$ & $3 / 13 / 2012$ \\
\hline Barren Ridge Solar & EIR & 336 & 0.92 & $1 / 4 / 2011$ & $12 / 6 / 2011$ \\
\hline Barren Ridge Solar & EIR & & & $3 / 8 / 2010$ & \\
\hline Beacon Photovoltaic Project & CEC/EIR & 1740 & 4.77 & $3 / 14 / 2008$ & 12/18/2012 \\
\hline Bechtel Soda Mountain Solar Project & NEPA & & & $10 / 22 / 2012$ & \\
\hline Beltran Ranch Solar Facility & EIR & 532 & 1.46 & $11 / 3 / 2011$ & $4 / 18 / 2013$ \\
\hline Blythe Solar Power Project & CEC/NEPA & 427 & 1.17 & $8 / 24 / 2009$ & $10 / 25 / 2010$ \\
\hline Broadwell SEGS & NEPA & & & $1 / 23 / 2007$ & \\
\hline Cal City Solar & EIR & & & $3 / 8 / 2010$ & \\
\hline Calexico Solar Farm 1 & EIR & 257 & 0.70 & $7 / 21 / 2011$ & $4 / 3 / 2012$ \\
\hline Calexico Solar Farm 2 & EIR & 253 & 0.69 & $7 / 25 / 2011$ & $4 / 3 / 2012$ \\
\hline Calico Solar Project I & CEC/EIR & 1661 & 4.55 & $12 / 2 / 2008$ & $6 / 20 / 2013$ \\
\hline California Valley Solar Ranch & EIR & 812 & 2.22 & 1/27/2009 & $4 / 19 / 2011$ \\
\hline Calipatria Solar Farm I & EIR & 397 & 1.09 & $7 / 27 / 2011$ & $8 / 27 / 2012$ \\
\hline Campo Verde & EIR & 286 & 0.78 & $11 / 15 / 2011$ & $8 / 27 / 2012$ \\
\hline Carrizo Energy Solar Farm & CEC & 755 & 2.07 & $10 / 25 / 2007$ & $11 / 18 / 2009$ \\
\hline Catalina Solar Project & EIR & 291 & 0.80 & $2 / 18 / 2011$ & $12 / 6 / 2011$ \\
\hline Centinela Solar Energy & EIR & 404 & 1.11 & $11 / 18 / 2010$ & $12 / 27 / 2011$ \\
\hline Central Antelope Dry Ranch & EIR & & & $6 / 13 / 2012$ & \\
\hline Desert Harvest & NEPA & 541 & 1.48 & $9 / 19 / 2011$ & $3 / 13 / 2013$ \\
\hline Desert Sunlight & NEPA & 573 & 1.57 & $1 / 13 / 2010$ & $8 / 9 / 2011$ \\
\hline Fink Road Solar Farm & EIR & 469 & 1.28 & $1 / 6 / 2011$ & $4 / 19 / 2012$ \\
\hline
\end{tabular}




\begin{tabular}{|c|c|c|c|c|c|}
\hline \multicolumn{6}{|c|}{ PROCESS TIME TOPICS } \\
\hline Project Name & $\begin{array}{c}\text { Public } \\
\text { Process Used } \\
\text { For Dates }\end{array}$ & $\begin{array}{c}\text { Total } \\
\text { Process } \\
\text { Time (Days) }\end{array}$ & $\begin{array}{c}\text { Total } \\
\text { Process } \\
\text { Time (Years) }\end{array}$ & $\begin{array}{l}\text { Public Review } \\
\text { Process Start }\end{array}$ & $\begin{array}{c}\text { Public } \\
\text { Review } \\
\text { Process End }\end{array}$ \\
\hline Five Points Solar Park & EIR & & & $11 / 29 / 2012$ & \\
\hline Fort Irwin Solar Power Project & NEPA & & & & \\
\hline Gateway Solar Project & EIR & & & & \\
\hline Genesis Solar Energy Project & CEC/NEPA & 429 & 1.18 & $8 / 31 / 2009$ & $11 / 3 / 2010$ \\
\hline Gray Butte Solar Array Project & EIR & & & $11 / 24 / 2009$ & \\
\hline Harper Lake Solar Plant & State & 718 & 1.97 & $2 / 27 / 1988$ & $2 / 14 / 1990$ \\
\hline Henrietta Solar Project & EIR & 454 & 1.24 & $5 / 10 / 2011$ & $8 / 6 / 2012$ \\
\hline Hidden Hills Solar Electric Generating System & CEC & 608 & 1.67 & $8 / 5 / 2011$ & $4 / 4 / 2013$ \\
\hline Imperial Solar Energy Center South & EIR & 390 & 1.07 & $6 / 11 / 2010$ & $7 / 6 / 2011$ \\
\hline Imperial Solar Energy Center West & EIR & 438 & 1.20 & $6 / 11 / 2010$ & $8 / 23 / 2011$ \\
\hline Imperial Valley Solar Project & CEC/NEPA & 827 & 2.27 & $6 / 30 / 2008$ & $10 / 5 / 2010$ \\
\hline Inspiration Solar Generation Farm & EIR & & & $7 / 20 / 2011$ & \\
\hline Ivanpah Solar Electric Generating System & CEC & 1118 & 3.06 & $8 / 31 / 2007$ & $9 / 22 / 2010$ \\
\hline Johnson Valley SEGS & CEC/NEPA & & & $5 / 23 / 2011$ & \\
\hline Kern Solar Ranch & EIR & & & $1 / 25 / 2013$ & \\
\hline Kramer Junction SEGS & State & 505 & 1.38 & $1 / 6 / 1987$ & $5 / 25 / 1988$ \\
\hline Liberty Solar Generation Project & EIR & & & $6 / 22 / 2011$ & \\
\hline Lotus Solar Farm & EIR & 210 & 0.58 & $6 / 12 / 2012$ & $1 / 8 / 2013$ \\
\hline McCoy Solar Energy Center & NEPA & 560 & 1.53 & $8 / 29 / 2011$ & $3 / 11 / 2013$ \\
\hline Midway Solar Farm 1 & EIR & 396 & 1.08 & $7 / 28 / 2011$ & $8 / 27 / 2012$ \\
\hline Midway Solar Farm 2 & EIR & 396 & 1.08 & $7 / 28 / 2011$ & $8 / 27 / 2012$ \\
\hline Monte Vista Solar Array & EIR & & & $3 / 8 / 2010$ & \\
\hline Mount Signal Solar Farm & EIR & 257 & 0.70 & $7 / 21 / 2011$ & $4 / 3 / 2012$ \\
\hline Mountain House Solar Farm & EIR & & & & \\
\hline Mustang & EIR & 379 & 1.04 & $7 / 24 / 2011$ & $8 / 6 / 2012$ \\
\hline North Star Power 1 & EIR & 441 & 1.21 & $1 / 27 / 2011$ & $4 / 12 / 2012$ \\
\hline North Valley Solar Generation Project & EIR & & & $6 / 20 / 2011$ & \\
\hline Oro Verde Solar & EIR & & & $5 / 23 / 2013$ & \\
\hline Palen Solar Power Project & CEC & 478 & 1.31 & $8 / 24 / 2009$ & $12 / 15 / 2010$ \\
\hline
\end{tabular}




\begin{tabular}{|c|c|c|c|c|c|}
\hline \multicolumn{6}{|c|}{ PROCESS TIME TOPICS } \\
\hline Project Name & $\begin{array}{l}\text { Public } \\
\text { Process Used } \\
\text { For Dates }\end{array}$ & $\begin{array}{c}\text { Total } \\
\text { Process } \\
\text { Time (Days) }\end{array}$ & $\begin{array}{c}\text { Total } \\
\text { Process } \\
\text { Time (Years) }\end{array}$ & $\begin{array}{l}\text { Public Review } \\
\text { Process Start }\end{array}$ & $\begin{array}{c}\text { Public } \\
\text { Review } \\
\text { Process End }\end{array}$ \\
\hline Panoche Valley Solar Farm & EIR & 245 & 0.67 & $3 / 1 / 2010$ & $11 / 1 / 2010$ \\
\hline Quinto Solar Photovoltaic Project & EIR & 691 & 1.89 & $12 / 16 / 2010$ & $11 / 6 / 2012$ \\
\hline Regulus Solar & EIR & 582 & 1.59 & $5 / 9 / 2011$ & $12 / 11 / 2012$ \\
\hline Rice Solar Energy Project & CEC & 420 & 1.15 & $10 / 21 / 2009$ & $12 / 15 / 2010$ \\
\hline Ridgecrest & CEC & & & $9 / 1 / 2009$ & \\
\hline Rio Mesa Solar Electric Generating Facility & CEC & 634 & 1.74 & $10 / 14 / 2011$ & 7/9/2013 \\
\hline Riverbluff Solar Energy Park & EIR & & & & \\
\hline Rosamond Solar & EIR & 248 & 0.68 & $3 / 8 / 2010$ & $11 / 11 / 2010$ \\
\hline Rosamond Solar Array & EIR & & & $3 / 8 / 2010$ & \\
\hline Rugged Solar Farm & EIR & & & $12 / 6 / 2012$ & \\
\hline Salton Sea Solar Farm 1 & EIR & & & & \\
\hline Salton Sea Solar Farm 2 & EIR & & & & \\
\hline Silverleaf & EIR & & & $3 / 21 / 2012$ & \\
\hline Solargen Panoche Valley Solar Farm & EIR & 225 & 0.62 & $3 / 1 / 2010$ & 10/12/2010 \\
\hline Sonoran West & CEC & 1262 & 3.46 & $5 / 12 / 2009$ & $10 / 25 / 2012$ \\
\hline Springbok Solar & EIR & 438 & 1.20 & $1 / 13 / 2013$ & $3 / 27 / 2014$ \\
\hline Stateline Solar Farm & NEPA & 582 & 1.59 & $8 / 4 / 2011$ & $3 / 8 / 2013$ \\
\hline Tierra del Sol & EIR & & & $12 / 6 / 2012$ & \\
\hline Topaz Solar Farm & EIR & 1105 & 3.03 & $7 / 2 / 2008$ & $7 / 12 / 2011$ \\
\hline Tranquillity Solar Generating Facility & EIR & & & $10 / 16 / 2013$ & \\
\hline Westlands Solar Park & EIR & & & $3 / 12 / 2013$ & \\
\hline Westside Solar Ranch & EIR & 105 & 0.29 & $7 / 22 / 2010$ & $11 / 4 / 2010$ \\
\hline Willow Springs Solar Array & EIR & & & $3 / 8 / 2010$ & \\
\hline
\end{tabular}




\section{APPENDIX G: DATABASE CONSTRUCTION TOPICS}




\begin{tabular}{|c|c|c|c|c|c|}
\hline \multicolumn{6}{|c|}{ CONSTRUCTION TOPICS } \\
\hline Project Name & $\begin{array}{c}\text { Construction } \\
\text { Start }\end{array}$ & $\begin{array}{l}\text { Estimated } \\
\text { Online Date }\end{array}$ & Online & $\begin{array}{c}\text { Start Online } \\
\text { Date }\end{array}$ & $\begin{array}{c}\text { Complete } \\
\text { Online } \\
\text { Date }\end{array}$ \\
\hline Abengoa Mojave Solar & 2011 & 2014 & No & & \\
\hline Adame 1 & & & No & & \\
\hline Alpaugh 50 & 2012 & 2012 & Yes & 2013 & 2013 \\
\hline Alpine Solar Project & 2011 & 2012 & Yes & 2013 & 2013 \\
\hline AV Solar Ranch One & 2011 & 2013 & Partial & 2013 & \\
\hline Avenal Photovoltaic Solar Farm & 2010 & 2011 & Yes & 2011 & 2011 \\
\hline AVSP $1 \& 2$ & 2013 & 2014 & No & & \\
\hline Barren Ridge Solar & & & No & & \\
\hline Barren Ridge Solar & & & No & & \\
\hline Beacon Photovoltaic Project & & 2011 & No & & \\
\hline Bechtel Soda Mountain Solar Project & & & No & & \\
\hline Beltran Ranch Solar Facility & & & No & & \\
\hline Blythe Solar Power Project & & 2015 & No & & \\
\hline Broadwell SEGS & & & No & & \\
\hline Cal City Solar & & & No & & \\
\hline Calexico Solar Farm 1 & & & No & & \\
\hline Calexico Solar Farm 2 & & & No & & \\
\hline Calico Solar Project I & & & No & & \\
\hline California Valley Solar Ranch & 2011 & 2012 & Partial & 2012 & \\
\hline Calipatria Solar Farm I & & & No & & \\
\hline Campo Verde & 2013 & 2013 & No & & \\
\hline Carrizo Energy Solar Farm & & & No & & \\
\hline Catalina Solar Project & 2012 & 2012 & Yes & 2012 & 2013 \\
\hline Centinela Solar Energy & 2012 & 2014 & No & & \\
\hline Central Antelope Dry Ranch & & 2014 & No & & \\
\hline Desert Harvest & & 2014 & No & & \\
\hline Desert Sunlight & 2011 & 2015 & No & & \\
\hline Fink Road Solar Farm & & & No & & \\
\hline
\end{tabular}




\begin{tabular}{|c|c|c|c|c|c|}
\hline \multicolumn{6}{|c|}{ CONSTRUCTION TOPICS } \\
\hline Project Name & $\begin{array}{c}\text { Construction } \\
\text { Start }\end{array}$ & $\begin{array}{l}\text { Estimated } \\
\text { Online Date }\end{array}$ & Online & $\begin{array}{c}\text { Start Online } \\
\text { Date }\end{array}$ & $\begin{array}{c}\text { Complete } \\
\text { Online } \\
\text { Date }\end{array}$ \\
\hline Five Points Solar Park & & & No & & \\
\hline Fort Irwin Solar Power Project & & 2013 & no & & \\
\hline Gateway Solar Project & & & no & & \\
\hline Genesis Solar Energy Project & 2011 & 2013 & No & & \\
\hline Gray Butte Solar Array Project & & & No & & \\
\hline Harper Lake Solar Plant & pre 2000 & & Yes & 1991 & 1991 \\
\hline Henrietta Solar Project & & 2016 & No & & \\
\hline Hidden Hills Solar Electric Generating System & & 2016 & No & & \\
\hline Imperial Solar Energy Center South & 2011 & 2013 & Partial & 2013 & \\
\hline Imperial Solar Energy Center West & & 2016 & No & & \\
\hline Imperial Valley Solar Project & & 2015 & No & & \\
\hline Inspiration Solar Generation Farm & & & No & & \\
\hline Ivanpah Solar Electric Generating System & 2010 & 2013 & Partial & 2013 & \\
\hline Johnson Valley SEGS & & & No & & \\
\hline Kern Solar Ranch & & & No & & \\
\hline Kramer Junction SEGS & pre 2000 & & Yes & 1987 & 1989 \\
\hline Liberty Solar Generation Project & & & No & & \\
\hline Lotus Solar Farm & & & No & & \\
\hline McCoy Solar Energy Center & & & No & & \\
\hline Midway Solar Farm 1 & & & No & & \\
\hline Midway Solar Farm 2 & & 2013 & No & & \\
\hline Monte Vista Solar Array & & & No & & \\
\hline Mount Signal Solar Farm & 2012 & 2014 & No & & \\
\hline Mountain House Solar Farm & & & no & & \\
\hline Mustang & & & No & & \\
\hline North Star Power 1 & & & No & & \\
\hline North Valley Solar Generation Project & & & No & & \\
\hline Oro Verde Solar & & & No & & \\
\hline Palen Solar Power Project & & & No & & \\
\hline
\end{tabular}




\begin{tabular}{|c|c|c|c|c|c|}
\hline \multicolumn{6}{|c|}{ CONSTRUCTION TOPICS } \\
\hline Project Name & $\begin{array}{c}\text { Construction } \\
\text { Start }\end{array}$ & $\begin{array}{l}\text { Estimated } \\
\text { Online Date }\end{array}$ & Online & $\begin{array}{c}\text { Start Online } \\
\text { Date }\end{array}$ & $\begin{array}{c}\text { Complete } \\
\text { Online } \\
\text { Date }\end{array}$ \\
\hline Panoche Valley Solar Farm & & & No & & \\
\hline Quinto Solar Photovoltaic Project & & 2014 & No & & \\
\hline Regulus Solar & & 2013 & No & & \\
\hline Rice Solar Energy Project & & 2013 & No & & \\
\hline Ridgecrest & & & No & & \\
\hline Rio Mesa Solar Electric Generating Facility & & & No & & \\
\hline Riverbluff Solar Energy Park & & & no & & \\
\hline Rosamond Solar & & & No & & \\
\hline Rosamond Solar Array & & & No & & \\
\hline Rugged Solar Farm & & & No & & \\
\hline Salton Sea Solar Farm 1 & & & no & & \\
\hline Salton Sea Solar Farm 2 & & & no & & \\
\hline Silverleaf & & 2016 & No & & \\
\hline Solargen Panoche Valley Solar Farm & & & No & & \\
\hline Sonoran West & & & No & & \\
\hline Springbok Solar & & & No & & \\
\hline Stateline Solar Farm & & & No & & \\
\hline Tierra del Sol & & & No & & \\
\hline Topaz Solar Farm & 2011 & 2014 & No & & \\
\hline Tranquillity Solar Generating Facility & & & No & & \\
\hline Westlands Solar Park & & & No & & \\
\hline Westside Solar Ranch & & & No & & \\
\hline Willow Springs Solar Array & & & No & & \\
\hline
\end{tabular}

